University of Michigan Law School University of Michigan Law School Scholarship Repository

Articles

Faculty Scholarship

2003

\title{
Equal Protection and Disparate Impact: Round Three
}

Richard A. Primus

University of Michigan Law School, raprimus@umich.edu

Available at: https://repository.law.umich.edu/articles/527

Follow this and additional works at: https://repository.law.umich.edu/articles

Part of the Civil Rights and Discrimination Commons, Fourteenth Amendment Commons, Law and Race Commons, Legislation Commons, and the Supreme Court of the United States Commons

\section{Recommended Citation}

Primus, Richard A. "Equal Protection and Disparate Impact: Round Three." Harv. L. Rev. 117, no. 2 (2003): 494-587.

This Article is brought to you for free and open access by the Faculty Scholarship at University of Michigan Law School Scholarship Repository. It has been accepted for inclusion in Articles by an authorized administrator of University of Michigan Law School Scholarship Repository. For more information, please contact mlaw.repository@umich.edu. 


\title{
EQUAL PROTECTION AND DISPARATE IMPACT: ROUND THREE
}

\author{
Richard A. Primus*
}

\begin{abstract}
Prior inquiries into the relationship between equal protection and disparate impact have focused on whether equal protection entails a disparate impact standard and whether laws prohibiting disparate impacts can qualify as legislation enforcing equal protection. In this Article, Professor Primus focuses on a third question: whether equal protection affirmatively forbids the use of statutory disparate impact standards. Like affirmative action, a statute restricting racially disparate impacts is a race-conscious mechanism designed to reallocate opportunities from some racial groups to others. Accordingly, the same individualist view of equal protection that has constrained the operation of affirmative action might also raise questions about disparate impact laws. Those questions can be satisfactorily answered: the disparate impact standards of statutes such as Title VII are not now unconstitutional. But by exploring the tensions between those standards and the now-prevailing view of equal protection, the Article illuminates many indeterminacies in both of those legal concepts. It also argues against interpreting disparate impact standards in ways that most easily align with the values of individualist equal protection. Such interpretations offer easier defenses against constitutional attack, but they also threaten to cleanse antidiscrimination law of its remaining concern with inherited racial hierarchy.
\end{abstract}

\section{INTRODUCTION}

The relationship between equal protection and facially neutral practices with discriminatory effects has been the subject of two rounds of legal questions. In the first round, the issue was whether courts would sustain equal protection challenges to facially neutral state action that was not intended to be discriminatory but had dis-

* Assistant Professor of Law, University of Michigan. My foremost thanks go to Evan Caminker, David Franklin, Don Herzog, Deborah Malamud, and Reva Siegel. No less sincerely, I thank Richard Banks, Steve Croley, John Donohue, Danna Drori, Ariela Dubler, Noah Feldman, Sam Gross, Daniel Halberstam, Michael Heller, Rick Hills, Bradley Joondeph, Ellen Katz, AnnaRose Mathieson, Nina Mendelson, John Pottow, Cathy Sharkey, Jeannie Suk, Nelson Tebbe, Mark Tushnet, Molly S. Van Houweling, Christina Whitman, Katrina Wyman, the participants in workshops at the Georgetown University Law Center and Harvard Law School, and the denizens of Kalorama College and Mintwood Manor. For help with research, I thank Adam Flake and Hope Spencer, as well as Margaret Leary and the staff of the University of Michigan Law Library. Research for this Article was funded in part by the Cook Endowment. I also thank Karen Rushlow for terrific administrative assistance and the students in my Fall 2002 seminar on disparate impact law for their patient and gentle skepticism. 
criminatory effects. ${ }^{1}$ Washington $v$. Davis ${ }^{2}$ answered no to that question, leaving the choice whether to impose disparate impact standards to legislators. ${ }^{3}$ In the second round, the issue was whether federal statutes prohibiting facially neutral practices with racially disparate impacts were valid only as commerce legislation or also as means of enforcing equal protection under Section 5 of the Fourteenth Amendment. ${ }^{4}$ This Article raises a third issue, one that lies beyond the Section 5 question. Rather than asking whether equal protection is a source of authority for disparate impact statutes, this Article examines whether equal protection could prohibit the passage of such statutes because of their overt concern with race. The question is analytic and conceptual rather than predictive: it seems unlikely that disparate impact law will actually be held unconstitutional. Nonetheless, there are serious conceptual tensions between modern equal protection doctrine and disparate impact law, tensions that are worth exploring for the light they shed on both disparate impact law and equal protection itself.

The idea that equal protection might affirmatively prohibit the use of statutory disparate impact standards departs significantly from settled ways of thinking about antidiscrimination law. ${ }^{5}$ The Davis Court itself said in dicta that Congress could use disparate impact standards

1 See, e.g., Paul Brest, The Supreme Court, 1975 Term-Foreword: In Defense of the Antidiscrimination Principle, 9o HARV. L. REv. I, 4-5, 22-26 (1976); Owen M. Fiss, Groups and the Equal Protection Clause, 5 PHIL. \& PUB. AFF. 107, 14I-46 (I976).

2426 U.S. $229(1976)$.

3 Id. at 248 .

4 Between City of Boerne v. Flores, 52 I U.S. 507, 536 (1997), which invalidated the Religious Freedom Restoration Act of 1993 as exceeding Congress's Section 5 power, and Nevada Department of Human Resources v. Hibbs, I23 S. Ct. 1972, I98 I (2003), which sustained the Family and Medical Leave Act as a valid exercise of that power, the scope of Congress's Section 5 enforcement power was a dominant preoccupation of leading public law theorists. See, e.g., Christine Jolls, Antidiscrimination and Accommodation, II5 HARV. L. REV. 642 (200I); Larry D. Kramer, The Supreme Court, 2000 Term-Foreword: We the Court, II5 HARV. L. REV. 4, I36-53 (2001); Daniel J. Meltzer, Congress, Courts, and Constitutional Remedies, 86 GEO. L.J. 2537 (I998); Robert C. Post \& Reva B. Siegel, Equal Protection by Law: Federal Antidiscrimination Legislation After Morrison and Kimel, I IO YALE L.J. 44I (2000); Robert C. Post \& Reva B. Siegel, Legislative Constitutionalism and Section Five Power: Policentric Interpretation of the Family and Medical Leave Act, I I 2 YALE L.J. 1943 (2003). Whether the Section 5 power is broad enough to support Title VII's disparate impact doctrine has also been a contested question among lower courts. Compare Okruhlik v. Univ. of Ark. ex rel. May, 255 F.3d 615, 626-27 (8th Cir. 200I) (holding that Congress may enact Title VII's disparate impact standard under Section 5), and In re Employment Discrimination Litig. Against Ala., I98 F.3d 1305, 132 I-24 (I Ith Cir. I999) (same), with Erickson v. Bd. of Governors, 207 F.3d 945, 952 (7th Cir. 2000) (suggesting that Title VII's disparate impact standard exceeds Congress's Section 5 authority). The issue remains officially unresolved, but Hibbs may reduce the intensity of this debate by marking a limit to the Court's contraction of Congress's Section 5 power.

5 See Deborah Malamud, Values, Symbols, and Facts in the Affirmative Action Debate, 95 MICH. L. REV. I668, I693 (I997) (commenting on the near-universal acceptance of disparate impact theory as a valid part of antidiscrimination law). 
in antidiscrimination statutes if it so chose. ${ }^{6}$ The leading example of a disparate impact statute known to the Davis Court was, of course, Title VII of the Civil Rights Act of $1964,{ }^{7}$ which addressed the effects of facially neutral employment criteria on different racial groups. ${ }^{8}$ But equal protection has changed a great deal since Davis was decided, and the changes raise questions about a statute that places people in racial categories and measures liability in part by reference to the allocation of employment opportunities among those racial groups. As exemplified in decisions such as City of Richmond v. J.A. Croson Co., 9 Shaw v. Reno, ${ }^{10}$ Adarand Constructors, Inc. v. Pena, ${ }^{11}$ and Gratz v. Bollinger, ${ }^{12}$ equal protection has become hostile to government action that aims to allocate goods among racial groups, even when intended to redress past discrimination. ${ }^{13}$ Pre-Davis, many courts and commentators believed that state actions creating disparate impacts violated equal protection; ${ }^{14}$ post-Adarand, one could well ask whether state actions prohibiting disparate impact violate equal protection. ${ }^{15}$

6 See Davis, 426 U.S. at 248.

7 Pub. L. No. 88-352, $\$ \S 70 I-716,78$ Stat. $241,253^{-66}$ (codified as amended at $4^{2}$ U.S.C. $\S \S 2000$ e to $2000 \mathrm{e}-2(2000))$.

8 See Griggs v. Duke Power Co., 40I U.S. 424, 426-3I (I97 I) (interpreting section 703(a)(2) of Title VII as creating a cause of action to challenge employment criteria that have statistically disparate effects on different racial groups).

9488 U.S. 469,511 ( 1989 ) (plurality opinion) (striking down an affirmative action plan for municipal subcontracting).

10509 U.S. $630,657-58$ (1993) (finding that a congressional reapportionment plan creating two majority-black districts gave rise to a claim under the Equal Protection Clause).

115 I5 U.S. 200, 227 (1995) ("[T]he Fifth and Fourteenth Amendments to the Constitution protect persons, not groups.").

12 I $23 \mathrm{~S}$. Ct. 24II, 2430-3 I (2003) (invalidating the University of Michigan's undergraduate affirmative action policy).

13 An important decision that might seem to limit this trend is Grutter v. Bollinger, $123 \mathrm{~S}$. Ct. 2325, 2347 (2003), which upheld the University of Michigan Law School's affirmative action policy. Without question, Grutter is important. Nevertheless, it does less to reverse the existing trend than one might think, in part because it maintains the previous decisions' resolute focus on the individual as the unit of analysis. See infra Part III.

14 See, e.g., Castro v. Beecher, 459 F.2d 725, 732-33 (Ist Cir. 1972) (holding that an employer must justify employment criteria that have a racially discriminatory impact); Chance $v$. Bd. of Exam'rs, 458 F.2d I167, I176-77 (2d Cir. 1972) (affirming a lower court decision that the examination procedure a city used to assess candidates for school supervisory positions resulted in "a disparity of sufficient magnitude to amount to a prima facie case of invidious de facto discrimination"); Fiss, supra note I, at I45-46 (suggesting that disparate impact doctrine is justified if the antidiscrimination principle is primarily concerned with the welfare of disadvantaged groups).

15 Although this Article focuses on the disparate impact standard of Title VII, its implications are broader. The recognition that disparate impact standards are constitutionally problematic would destabilize a range of federal laws besides Title VII, including not only the Voting Rights Act - the race-consciousness of which has already attracted scholarly attention, see sources cited infra note 16 - but also laws such as the No Child Left Behind Act of 200 I, Pub. L. No. 107-I 10, I I5 Stat. 1425 (2002), which uses disparate impact standards to measure educational achievement in public schools. It would also imperil state laws that use disparate impact standards. 
This turnabout has been underway for years. Accordingly, one might wonder why this Article is the first serious consideration of the problem. ${ }^{16}$ An important reason, I suspect, has to do with the way that traditional constitutional discourse has shaped our collective imagination. When judges and legal scholars describe the relationship between equal protection and disparate impact, it is standard for them to repeat the theory that the Supreme Court put forward in Davis: the Fourteenth Amendment does not prohibit practices that have disparate impacts, but legislatures can pass laws banning disparate impacts if they so choose. ${ }^{17}$ Only the first part of that theory is technically the

It also bears mention that Title VII's disparate impact doctrine applies to sex as well as race. See 42 U.S.C. $\$ 2000$-2(a)(2) (2000). If disparate impact doctrine as applied to race were an unconstitutional means of allocating employment opportunities among suspect groups, then the doctrine could be endangered with regard to sex as well. It seems likely, however, that a line could be drawn between race and sex on the grounds that sex discrimination, unlike race discrimination, is not subject to strict scrutiny under the Equal Protection Clause. See, e.g., Clark v. Jeter, 486 U.S. $456,46 \mathrm{I}$ ( 1988 ). This Article focuses on race because disparate impact doctrine is more likely to be vulnerable when applied to race than when applied to sex.

Title VII also covers national origin and religion. See 42 U.S.C. § $2000 \mathrm{e}-2(\mathrm{a})(2)$. This Article's analysis applies to national origin to the extent that it raises the same issues and implicates the same doctrinal frameworks as race. And as a practical matter, the issue of disparate impact with regard to religion simply does not arise in the Title VII context. There is only one reported case, ever and in any court, addressing a Title VII claim of disparate impact discrimination by religion. See EEOC v. Sambo's of Georgia, Inc., 530 F. Supp. 86, 92-93 (N.D. Ga. I 981) (rejecting a Sikh applicant's disparate impact challenge to a restaurant's policy requiring employees to be clean-shaven). The primary reason why the issue does not arise is that Title VII also requires reasonable accommodation of employees' religious practices. See 42 U.S.C. $\$ \$ 2000 \mathrm{e}$ (j), $2000 \mathrm{e}-$ 2(a)(I). Facially neutral employment policies will not have disparately adverse impacts on employees with different religious practices if the employees who would be adversely affected can avoid those effects through reasonable accommodation. For example, if Orthodox Jews can get the reasonable accommodation of not being required to work on Saturdays, then a workplace rule requiring employees to work on Saturdays will not have a disparate impact on Orthodox Jews. Accordingly, the question of Title VII disparate impact doctrine's viability in religion cases can be safely relegated to the margins of this Article.

16 One pedestrian explanation is that analogous but more politically contentious issues such as affirmative action or the race-conscious impact standard of the Voting Rights Act have drawn the field's attention. See, e.g., Gratz, I23 S. Ct. at 2430-3I (striking down an affirmative action policy for college admissions as not being narrowly tailored to achieve the asserted compelling state interest in diversity); Grutter, I23 S. Ct. at 2347 (upholding an affirmative action policy for law school admissions); Holder v. Hall, $5^{\text {I } 2}$ U.S. 874,885 (I 994) (holding that the size of a governing authority cannot be attacked in a vote dilution claim brought under the Voting Rights Act); Heather K. Gerken, Understanding the Right to an Undiluted Vote, II4 HARV. L. REV. I663, I68 I-89 (200I) (arguing that vote dilution is an aggregate harm that forces courts to examine the treatment of groups when determining individual claims); Lani Guinier, [E]racing Democracy: The Voting Rights Cases, 108 HARV. L. REV. I09, I I (1994) (noting that "the growing tendency ... to think about equal opportunity in purely individualistic terms" has threatened raceconscious districting under the Voting Rights Act). Nonetheless, it pays to consider deeper reasons why the constitutional problem on which this Article focuses has been overlooked.

17 See Erickson v. Bd. of Governors, 207 F.3d 945, 950 (7th Cir. 2000) (noting that Davis does not prohibit facially neutral laws and practices having a disparate impact); LAURENCE $\mathrm{H}$. TRIBE, AMERICAN CONSTITUTIONAL LAW $§$ I6-20, at I5 I I-I 2 (2d ed. I988) (observing that 
holding of Davis. The second part is dicta. But it is dicta that judges and lawyers have internalized for nearly thirty years. Constitutional lawyers hold both parts of the theory together in their heads, thus precluding the thought that laws prohibiting disparate impact might themselves be unconstitutional. As a result, the constitutional validity of the Davis dicta endorsing disparate impact statutes has never been examined.

Instead, progressive scholars have concentrated on attacking the holding of Davis. They have justifiably argued for a more historically embedded approach to equal protection, one that would use an impact standard to address continuing problems of inequality. ${ }^{18}$ But the law has not responded. ${ }^{19}$ On the contrary, equal protection has moved steadily away from the orientation that the progressive critics endorse. It has become more individualistic, ${ }^{20}$ more formal, ${ }^{21}$ and less concerned with history and social structure. ${ }^{22}$ In addition to further entrenching the conservative holding of Davis, these developments have put equal protection in tension with Davis's acquiescence to statutory disparate impact standards in laws such as Title VII.

How serious the tension is depends in part on how disparate impact statutes are characterized. As this Article describes, Title VII's disparate impact doctrine can be understood in several different ways, some of which are easier than others to reconcile with modern equal protection jurisprudence. To oversimplify for the moment, ${ }^{23}$ some readings of the prohibition on disparate impact see it as an evidentiary device aimed at ferreting out present discriminatory states of mind, ${ }^{24}$

the Court in Davis declared that no substantive constitutional violation had occurred, thus suggesting that a statutory disparate impact standard is acceptable under Davis).

18 See, e.g., Charles R. Lawrence III, The Id, the Ego, and Equal Protection: Reckoning with Unconscious Racism, 39 STAN. L. REV. 3I 7 (1987) (arguing against an equal protection jurisprudence that requires plaintiffs to prove deliberate discriminatory intent, pointing to the subconscious patterns of discrimination that are latent in America's historical and cultural heritage); Reva Siegel, Why Equal Protection No Longer Protects: The Evolving Forms of Status-Enforcing State Action, 49 STAN. L. REV. I II I, II4I-45 (I997) (arguing that equal protection litigation employing a disparate impact standard would more successfully disestablish historic patterns of race stratification); David A. Strauss, Discriminatory Intent and the Taming of Brown, 56 U. CHI. L. REV. 935, 937-39 (I989) (arguing that the discriminatory intent standard fails to provide meaningful results when applied rigorously).

19 I speak here of United States constitutional law. Other constitutional regimes have in fact adopted impact standards. See, e.g., British Columbia (Pub. Serv. Employee Relations Comm'n) v. BCGSEU, [ 1999] 3 S.C.R. 3 (Can.); Law v. Canada (Minister of Employment and Immigration), [1999] I S.C.R. 497 (Can.).

20 See infra Part III.

21 See infra Part I (discussing the adoption of strict scrutiny for all express racial classifications).

22 See infra section III.A.

23 Part II confronts complexities that this summary statement obscures.

24 See, e.g. Jolls, supra note 4 , at 652 (describing this view). Such a view of disparate impact raises few equal protection problems. After all, simple bans on intentional discrimination have 
while others see it as concerned with the lingering structural consequences of discrimination practiced in the past. ${ }^{25}$ Adopting an interpretation along the former lines would help preserve disparate impact doctrine against an equal protection attack by making it conform to the presentist, individualist approach that increasingly typifies equal protection itself.

I do not come to bury disparate impact law; I am sympathetic to the impulse to characterize the doctrine in whatever way makes its survival most likely. Nonetheless, disavowing the historically and group-oriented aspects of disparate impact law may be a gambit that sacrifices too much of what makes the doctrine valuable. As a practical matter, disparate impact litigation now plays a much smaller role than it once did in increasing employment opportunities for large numbers of nonwhite workers. ${ }^{26}$ But law's symbolic or expressive functions are sometimes more important than its immediate practical consequences, ${ }^{27}$ and the story we tell about disparate impact doctrine still plays a significant role in shaping how we think about the nature and purposes of antidiscrimination law. Acceding to a worldview on which racial inequity is primarily the product of present bad actors rather than largely a matter of historically embedded hierarchies fosters the misdescription of a central social problem and therefore helps make it less likely that the problem will be addressed through appropriate means. Thus, the growing tendency of equal protection jurisprudence to obscure the dynamics of group hierarchy and to truncate the memory of historical discrimination ${ }^{28}$ makes it all the more important to maintain, when possible, reminders within the law that historical discrimination continues to affect the status of racial groups. The more robust conceptions of disparate impact doctrine are one prominent locus of that idea. Abandoning that historical orientation in an

never been thought to be constitutionally problematic. If disparate impact law were merely another means to eliminate intentional discrimination, it would be almost as benign.

25 See infra section II.B.2, pp. 523-25.

26 See George Rutherglen, Abolition in a Different Voice, 78 VA. L. REV. 1463 , 1476 (1992) (book review). It is possible that the existing set of opportunities is protected by the continued existence of the doctrine, such that the disappearance of the doctrine would lead to a reduction in opportunities. But if disparate impact law chiefly forced workplace reforms that were compatible with rational business practices, there is little reason to think that employers freed from the disparate impact standard would revert to older and more exclusionary practices unless they were actively motivated by the desire to resegregate their workforces.

27 See Cass R. Sunstein, On the Expressive Function of Law, 144 U. PA. L. REV. 202 I, $2022-$ 24,2045 (I 996 ).

28 See, e.g., City of Richmond v. J.A. Croson Co., 488 U.S. 469, 505-06 (I 989) (plurality opinion) (declining to draw inferences about present conditions from past discrimination); Siegel, supra note 18 , at $\mathrm{I}_{142}$ (discussing how modern equal protection doctrine obscures a history of hierarchical status regimes). 
attempt to rescue the doctrine might sacrifice the very thing that is most worth saving.

Just as disparate impact law is susceptible of multiple interpretations, equal protection analysis encompasses more than one concern. Government action can run afoul of equal protection because it classifies people into racial groups, ${ }^{29}$ has an illicit motive, ${ }^{30}$ fails to treat people as individuals, ${ }^{31}$ or expresses disfavored ideas. ${ }^{32}$ The four Parts of this Article assess Title VII's disparate impact standard in light of these four aspects of equal protection.

Part I, which deals with classification, examines how courts actually decide what constitutes a racial classification, and it demonstrates that the disparate impact standard could be subjected to strict scrutiny for using such classifications. Part II deals with the legislative motives behind disparate impact doctrine, focusing on the temptation to save the disparate impact standard by denying that it aims to cure the effects of historical discrimination. Part III demonstrates that equal protection's commitment to individualism can conflict with Title VII's concern with groups, but it also argues that Title VII is sufficiently individualistic that this problem need not be fatal. Finally, Part IV turns to expressive harm, analyzing how a reviewing court could conclude that disparate impact doctrine expresses disfavored ideas about race.

These four aspects of equal protection doctrine - classification, motive, individualism, and expressive harm - are not a four-prong test stated in some authoritative case, nor are they a proposal for how equal protection adjudication should proceed. They are four themes that appear in important equal protection cases. No set of rules reliably governs how they interact, but it is possible to give rough characterizations of the different though overlapping spaces they occupy in equal protection inquiry. The issue of classification is mostly germane to whether a court should apply heightened scrutiny, but the determination that a particular law embodies an express classification is informed by concerns about motive and individualism. Motive and individualism are relevant both to the decision of what kind of scrutiny to apply and to the ultimate decision of a case. Motive, however, is the subject of many doctrinal rules connected to choices about levels of scrutiny, whereas the influence of individualism is more ambient and less disciplined. Expressive harm is not a substantive concern of its own; rather, it is a second-order concern that government conduct will manifest ideas contrary to substantive concerns regarding things like individualism. In this Article, Parts I and II (dealing with classification

29 See, e.g., Croson, 488 U.S. at 493-94.

30 See, e.g., Miller v. Johnson, 5 I 5 U.S. 900, $9 \mathrm{II}-\mathrm{I} 3$, 916 (I 995 ).

31 See, e.g., Gratz v. Bollinger, I 23 S. Ct. 24 I I 2428 (2003).

32 See, e.g., Shaw v. Reno, 509 U.S. 630, 647 (1993). 
and motive) mostly discuss whether Title VII's disparate impact provisions could be subject to strict scrutiny. Parts III and especially IV (dealing with individualism and expressive harm) are more abstract. Their concern is less with doctrinal levels of scrutiny and more with the ultimate reconcilability of equal protection and disparate impact law.

Traditionally, the most straightforward strategy for protecting disparate impact doctrine from a constitutional challenge would be to avoid heightened scrutiny altogether. In fact, until Grutter v. Bollinger, ${ }^{33}$ no equal protection decision of the Supreme Court had ever upheld a challenged practice under strict scrutiny, ${ }^{34}$ and observers could be forgiven for believing that strict scrutiny was always fatal in fact. ${ }^{35}$ In the wake of Grutter, however, disparate impact law could conceivably survive constitutional challenge inside the framework of strict scrutiny. Grutter destabilizes existing expectations about strict scrutiny, making it necessary to take seriously the possibility that some laws subject to strict scrutiny will nonetheless prove constitutional. It is too early to know how large a category of laws that will turn out to be; the role of strict scrutiny may be less determinate since Grutter than at any time since the doctrine's earliest years. But if Grutter offers hope for Title VII's disparate impact doctrine by holding that not all race-conscious and racially allocative laws are impermissible, it also suggests that the validation of disparate impact law may occur within the framework of strict scrutiny rather than outside it.

Two further introductory notes are in order, one about the ambitions of this Article and the other about its audience and its methods. First, on ambitions: As noted at the outset, the project of this Article is analytic rather than predictive. Even before the Supreme Court's decisions in Grutter and Nevada Department of Human Resources $v$. $H i b b s{ }^{36}$ a decision holding Title VII's disparate impact doctrine unconstitutional would have been unusually bold; after Grutter and $H i b b s$, the likelihood of a successful challenge to Title VII's disparate impact standard is entirely remote. The aim of this Article, however,

33 I 23 S. Ct. 2325 (2003).

34 The nearest example might be Korematsu v. United States, 323 U.S. 2 I 4 (1944), but Korematsu was a due process case, not an equal protection case. Id. at 2 I 7,223 (upholding a federal internment order directed at individuals of Japanese ancestry during World War II).

35 See Gerald Gunther, The Supreme Court, I97I Term-Foreword: In Search of Evolving Doctrine on a Changing Court: A Model for a Newer Equal Protection, 86 HARV. L. REV. I, 8 (1972); see also Peter J. Rubin, Reconnecting Doctrine and Purpose: A Comprehensive Approach to Strict Scrutiny After Adarand and Shaw, I49 U. PA. L. REV. I, 4 (2000) (stating that in practice, strict scrutiny constitutes a conclusion of invalidity rather than a kind of analysis). But see Adarand Constructors, Inc. v. Pena, 5 I5 U.S. 200, 237 (I995) ("[W]e wish to dispel the notion that strict scrutiny is 'strict in theory, but fatal in fact." (quoting Fullilove v. Klutznick, 448 U.S. 448, $5 \mathrm{I} 9$ (1980) (Marshall, J., concurring in the judgment))).

36 I23 S. Ct. $1972(2003)$. 
is to tease out the commitments of antidiscrimination law, not to foresee what the Supreme Court will do in fact. Moreover, the Article goes beyond using a static notion of "equal protection" to evaluate disparate impact law. Instead, it uses the issue of disparate impact law to map the contours of equal protection itself. As mentioned above, modern equal protection is informed by several different commitments and conceptions, all of which somehow relate to the idea of equality, but none of which provides an exclusive account of constitutional doctrine. I do not propose to show that one of those commitments or conceptions is the true essence of equal protection, either as a descriptive matter of what courts do or as a matter of my own normative preferences. But I do propose to expose many ambiguities and indeterminacies that exist within the cluster of ideas that travel together as "equal protection."

Second, this Article is conscious of the important role that normative predispositions play in shaping how people approach contestable doctrinal questions. My own view is that disparate impact is a proper standard for much of antidiscrimination law. I also disagree with significant parts of the Rehnquist Court's equal protection theory: I believe, for example, that Adarand was wrongly decided. Accordingly, my natural tendency is to read Adarand and other troublesome equal protection cases narrowly, resolving contestable issues in favor of the continued viability of the disparate impact standard. I expect that many in this Article's audience will share that tendency. But arguments that disparate impact law is still viable are of little use if they can persuade only that portion of the audience. Such arguments must be crafted in ways that are persuasive to those who believe that cases like Adarand were rightly decided: that perspective is now the perspective of equal protection jurisprudence. Accordingly, my account of how a historically conscious disparate impact doctrine can be compatible with the regime of $A$ darand is intended to be persuasive to that portion of the audience that disagrees with me about the desirability of that regime. This does not mean, of course, that I intend to pass myself off as believing that Adarand is correct. I will strive, however, to think from perspectives contrary to my own, and I hope my audience will do the same.

\section{RACIAL CLASSIFICATION}

Since the Supreme Court's decisions in Croson and Adarand, all laws using express racial classifications have been subject to strict scrutiny and can be sustained only in exceptional circumstances. ${ }^{37}$

37 See Adarand, 5 I 5 U.S. at 227, 235; City of Richmond v. J.A. Croson Co., 488 U.S. 469, 49394 (1989) (plurality opinion). In Croson, the Supreme Court sustained a challenge to a Richmond 


\section{Strict scrutiny applies regardless of whether the classifications benefit or burden historically disadvantaged groups, ${ }^{38}$ or even if they impose}

municipal government program that required prime contractors doing business with the city to subcontract at least thirty percent of the value of their awarded contracts to "Minority Business Enterprises"; for the purposes of the city plan, minorities were defined to include "Blacks, Spanish-speaking, Orientals, Indians, Eskimos, or Aleuts." Id. at 477-78. Writing for the Court, Justice O'Connor explained the decision in the language of colorblind liberalism, invoking "[t]he dream of a Nation of equal citizens in a society where race is irrelevant to personal opportunity and achievement." Id. at 505-06. Accordingly, she explained, any racial classification is subject to strict scrutiny under the Equal Protection Clause, regardless of which races may be benefited or burdened by the classification. Id. at 494 (O'Connor, J., joined by Rehnquist, C.J., and White and Kennedy, JJ.); see also id. at 520,527-28 (Scalia, J., concurring in the judgment) (providing a fifth vote for this proposition). Having settled on strict scrutiny, Justice O'Connor went on to invalidate Richmond's program because it was not supported by a compelling government interest. No compelling government interest supported the program, she wrote, partly because there was no identified past discrimination specifically in the Richmond construction industry. Croson, 488 U.S. at 505 . Even if there had been a compelling interest, the Court thought it likely that Richmond's method of aiffirmative action was insufficiently well-tailored to survive. Among other problems, the thirty percent quota did not seem to the Court to be narrowly tailored to anything "except perhaps to outright racial balancing," which was a nonstarter as a possible government aim. Id. at 507 .

In Adarand, decided six years later, the familiar 5-4 Rehnquist Court majority announced that Croson's colorblind application of strict scrutiny governs federal laws as well as state laws. See Adarand, 515 U.S. at 227 . The case presented a challenge to a program designed to increase the proportion of federal contracting work done by minority-owned businesses. Seeking to ensure that at least five percent of the value of contracts and subcontracts awarded by the federal government each fiscal year would go to businesses owned by "socially and economically disadvantaged individuals," Congress required most federal contracts to include a clause specifying that a general contractor would receive an additional payment if it hired subcontractors certified by the Small Business Administration (SBA) as owned by such disadvantaged individuals. Id. at 200 . The SBA's own rules provided that black, Hispanic, Asian Pacific, Subcontinent Asian, and Native American persons were presumed to be disadvantaged. Mountain Gravel Company, a general contractor with a contract to do highway construction for the Department of Transportation, awarded a subcontract to Gonzales Construction Company, a Hispanic-owned business, rather than to Adarand, a white-owned business, in spite of the fact that Adarand submitted a lower bid, because the federal financial incentive to hire minority-owned subcontractors overcame the difference between the two companies' bids. Adarand sued, claiming a violation of equal protection. The Tenth Circuit followed Metro Broadcasting, Inc. v. FCC, 497 U.S. 547 (I990), and applied a standard resembling intermediate scrutiny to the "benign" racial classification. See Adarand, 5 I5 U.S. at 2 Io. Metro Broadcasting was decided after Croson had held that the characterization of a racial classification as benign made no difference to the applicable level of scrutiny, but the Metro Broadcasting Court limited Croson to racial classifications deployed by state governments rather than by Congress. See Metro Broadcasting, 497 U.S. at 565. Congress, the Court reasoned, deserved special deference in matters of equal protection law, a deference grounded in the historic role of the Equal Protection Clause as a federal bulwark against state discrimination and reflected in Section 5 of the Fourteenth Amendment. See id. at 563. But between Metro Broadcasting and Adarand, Justice Clarence Thomas replaced Justice Thurgood Marshall on the Supreme Court. In Adarand, Justice Thomas provided the fifth vote to overrule Metro Broadcasting and to hold that strict scrutiny applies to federal racial classifications just as it applies to state ones. See Adarand, 5 I 5 U.S. at 235 .

38 See Croson, 488 U.S. at 494 (reaffirming the view that "the standard of review under the Equal Protection Clause is not dependent on the race of those burdened or benefited by a particular classification" (citing Wygant v. Jackson Board of Education, 476 U.S. 267, 279-80 (I986) (plurality opinion))). 
no differential burden or benefit on different racial groups. ${ }^{39}$ Many critics have characterized this doctrine as normatively and analytically misguided. ${ }^{40}$ As a descriptive matter, however, classification has clearly become central to equal protection doctrine.

The rule that all racially classificatory legislation is subject to strict scrutiny derives its strength from two intuitions, one normative and one administrative. The normative intuition is that the law should aspire to the ideal of colorblindness, according to which the government never takes notice of race. ${ }^{41}$ The administrative intuition is that it much easier to implement a rule that subjects all racial classifications to strict scrutiny than a rule that subdivides racial classifications, treating some one way and others differently. Applying different standards to benign and malign classificatory state action requires a prior

39 See Shaw v. Reno, 509 U.S. 630, 65 I (1993) (noting that "racial classifications receive close scrutiny even when they may be said to burden or benefit the races equally").

40 See, e.g., Elizabeth S. Anderson, Integration, Affirmative Action, and Strict Scrutiny, 77 N.Y.U. L. REV. I 195, I 234-37 (2002) (finding absurd the conclusion that a "bare" classification of people by race mechanically raises the prospect of a core equal protection violation); Jed Rubenfeld, The Anti-Antidiscrimination Agenda, I I YALE L.J. I I4 I, I I 75-76 (2002) (challenging the proposition that affirmative action deserves strict scrutiny because it threatens to promote entrenched racial stereotypes); Siegel, supra note I8, at I I4I-44; see also Reva B. Siegel, She the People: The Nineteenth Amendment, Sex Equality, Federalism, and the Family, I 5 HARV. L. REV. 948 , $1025-27(2002)$ (arguing, with reference to sex, that the avoidance of formally classificatory laws only "mask[s] the gender-specificity of the regulated conduct").

41 In the simple sense described above, colorblindness is an apt metaphor for a ban on all racial classifications: a colorblind government simply takes no notice of the color, and by implication the race, of the people it governs. In a more subtle way, however, the language of blindness is not a precise match for the view of equal protection as a ban on racial classifications. As a metaphor, blindness suggests the inability to perceive some feature of the world that exists independent of the viewer. But race, unlike color, is not an objective physical phenomenon. It is an intersubjective phenomenon, the product of a shared set of meanings among a community of people who form their understandings under one another's influences, and the government's influence has long played a powerful role in the construction of race. See, e.g., DAVID A. HOLLINGER, POSTETHNiC AMERICA: Beyond MUlTiCulturalism 32-33 (i995) (describing legal rules that have shaped racial categories and designated the race of persons of mixed ancestry). See generally Ariela J. Gross, Litigating Whiteness: Trials of Racial Determination in the Nineteenth-Century South, IO8 YALE L.J. I09 (I998) (describing the processes by which trials have shaped racial boundaries). By invoking a paradigm of pure perception, the metaphor of colorblindness implies that race is something apprehended rather than constructed, thereby obscuring government's role in shaping racial categories in the first place.

This misleading feature of the term "colorblind" is not entirely incidental to the way it is used. Laws containing express racial classifications are today much more likely to be aimed at improving the position of historically oppressed groups than at exacerbating their disadvantage. Accordingly, the colorblindness imagery now functions mostly to impede efforts to dismantle old racial hierarchies. See, e.g., Adarand, 515 U.S. at 239 (Scalia, J., concurring in part and concurring in the judgment) (using the colorblindness argument to oppose affirmative action); see also Randall Kennedy, Persuasion and Distrust: A Comment on the Affirmative Action Debate, 99 HARV. L. REV. I327, I334-37 (1986) (describing the anti-affirmative-action valence of the colorblindness argument). The choice to keep government out of active efforts to dismantle racial hierarchies seems more appropriate if those hierarchies are not a product of the government's prior acts than if the government played a large role in creating those hierarchies in the first place. 
determination of whether particular government action is benign or malign, and the Court has wondered aloud how that distinction could be made without careful scrutiny. ${ }^{42}$ Instead of requiring courts to make subjective judgments when deciding which standard to apply, Croson and Adarand seem to provide a formal rule that cleanly dictates the appropriate level of scrutiny in all covered cases.

This promise of an easily administrable rule is overly optimistic. The rule that all statutes with express racial classifications are subject to strict scrutiny can only be uncontroversially applied if everyone can agree on what an "express racial classification" is, and "express racial classification" is not a self-defining term. A commonsense conception of "racial classifications" might hold that such classifications exist whenever a law, regulation, order, or other statement of government practice or policy requires that persons be identified according to specified racial categories. "Express racial classifications" would then exist only if such a requirement appeared in the plain text of the law, regulation, order, or statement at issue. In practice, however, these definitions are not followed, and many practices that do involve government actors' identifying people by race are not always subject to strict scrutiny. Examples include the police use of racial descriptions of criminal suspects, ${ }^{43}$ the Census Bureau's collection of demographic data ${ }^{44}$ state legislatures' race-based redistricting practices, ${ }^{45}$ and social service agencies' race-conscious adoption placements. ${ }^{46}$ These examples show that not all instances in which the government explicitly

42 See Croson, 488 U.S. at 493; see also Grutter v. Bollinger, I 23 S. Ct. 2325, 2338 (2003) (reiterating the difficulty of distinguishing benign classifications from illegitimate ones (quoting $\mathrm{Cro}$ son, 488 U.S. at 493)).

43 See infra pp. 5 I I-I3 (discussing Brown v. City of Oneonta, 22 I F.3d 329 (2d Cir. 2000)). For arguments against the view that reliance on suspect descriptions implicates racial classifications, see R. Richard Banks, Race-Based Suspect Selection and Colorblind Equal Protection Doctrine and Discourse, 48 UCLA L. REV. 1075, 1092-96 (2001).

44 See Morales v. Daley, I 16 F. Supp. 2d 801, 814-15 (S.D. Tex. 2000) (upholding census questions concerning race against an equal protection challenge); see also Anderson, supra note 40, at 1234 n. 152 (describing the constitutional validity of racial classifications in statistical records under the Supreme Court's current jurisprudence); $c f$. Hamm v. Va. Bd. of Elections, 230 F. Supp. 156 , 158 (E.D. Va. I 964 ) ("If the purpose [for keeping racial data] is legitimate, the reason justifiable, then no infringement results."), aff'd sub nom. Tancil v. Woolls, 379 U.S. I9 (1964).

45 The Court treats districting plans as facially neutral even when drawn with significant attention to race: a plan itself is merely a shape on a map, which does not, by itself, classify anyone by race. See Shaw v. Reno, 509 U.S. 630, 649 (1993) (describing the challenged district as "race neutral on its face"); see also Gerken, supra note $\mathrm{I} 6$, at I695-96 (noting that Shaw involves a districting plan that is facially neutral because one "cannot look at a district line and immediately conclude that the government has employed a racial classification" (citation omitted)).

46 As a general matter, courts have accommodated the use of race as a criterion in adoption so long as race does not play such a prominent role that it precludes the possibility of a transracial placement. See R. Richard Banks, The Color of Desire: Fulfilling Adoptive Parents' Racial Preferences Through Discriminatory State Action, IO7 YALE L.J. 875, 905 \& n.135 (1998). 
considers the race of individuals are "express racial classifications" for purposes of equal protection doctrine. Some are, and some are not.

\section{A. Does Title VII Use Racial Classifications?}

Like the preceding examples, Title VII's disparate impact doctrine is race-conscious. It is not easy, however, to deduce whether it involves an express classification under Adarand.

If life were simple, the existence of an express classification would be a function of the plain language of a statute or regulation. The relevant analysis of Title VII's disparate impact provisions would accordingly focus on the statutory language that creates liability for disparate impact. There is some irony here, given that Title VII's language has never been the real source of disparate impact doctrine. Though formally a statutory matter, liability for disparate impact in employment practices was engineered by the EEOC and the courts before it was ever clearly approved by Congress. The words "disparate impact" did not appear in the original language of Title VII, and there are respectable arguments for the proposition that the political coalition necessary for passing Title VII would not have approved such a standard. ${ }^{47}$ Nonetheless, the EEOC took the position that Title VII reached disparate impact as well as intentional discrimination, ${ }^{48}$ and several lower courts agreed. ${ }^{49}$

In 197I, the Supreme Court endorsed this reading of Title VII in Griggs v. Duke Power Co. ${ }^{50}$ The Griggs Court held that the language in section 703(a)(2) of Title VII, which makes it unlawful for an employer to "limit, segregate, or classify his employees in any way which would deprive or tend to deprive any individual of employment opportunities or otherwise adversely affect his status as an employee, because of such individual's race, color, religion, sex, or national ori-

47 See, e.g., Richard EPSTEIN, Forbidden Grounds: The CASE Against EmployMENT DISCRIMINATION LAWS I84-97 (1992); Robert Belton, The Dismantling of the Griggs Disparate Impact Theory and the Future of Title VII: The Need for a Third Reconstruction, 8 YALE L. \& POL'Y REV. 223, 223 (I 990) (finding the legislative history of Title VII inconclusive as to whether the statute bears on facially neutral employment practices that adversely impact racial minorities and women).

48 See EEOC Guidelines on Employee Selection Procedures, 29 C.F.R. \$ I607.3 (I970) ("The use of any test which adversely affects hiring, promotion, transfer or any other employment or membership opportunity of classes protected by Title VII constitutes discrimination unless: (a) the test has been validated and evidences a high degree of utility as hereinafter described; and (b) the person giving or acting upon the results of the particular test can demonstrate that alternative suitable hiring, transfer or promotion procedures are unavailable for his use.").

49 See, e.g., Parham v. Southwestern Bell Tel. Co., 433 F.2d 42 I, 426-27 (8th Cir. I97o) (holding that a facially neutral hiring practice of relying on referrals yielded a predictably low number of minority employees in violation of Title VII); Local I89, United Papermakers v. United States, 4 I 6 F.2d 980, 982-83 (5th Cir. I 969).

50 40I U.S. 424 (197I). 
gin," ${ }^{11}$ evinced congressional intent to prohibit disparate impact regardless of an employer's intentions. ${ }^{52}$ Although this reading of the statute has been widely criticized, ${ }^{53}$ Congress never overruled it, and disparate impact doctrine operated for twenty years with section 703(a)(2) as its only statutory grounding. Then, in the Civil Rights Act of $199 \mathrm{I},{ }^{54}$ Congress amended Title VII and placed the doctrine on firmer footing. In what became section $703(\mathrm{k})$ of Title VII, Congress for the first time put the words "disparate impact" into the statute and addressed the mechanics of bringing a disparate impact claim. ${ }^{55}$ The amended statute provides that

An unlawful employment practice based on disparate impact is established under this title only if -

(i) a complaining party demonstrates that a respondent uses a particular employment practice that causes a disparate impact on the basis of race, color, religion, sex, or national origin and the respondent fails to demonstrate that the challenged practice is job related for the position in question and consistent with business necessity; or

51 Civil Rights Act of 1964 , Pub. L. No. 88-352, $\$ 703(a)(2), 78$ Stat. 241,255 (codified as amended at 42 U.S.C. $\$ 2000-2(a)(2)(2000))$.

52 See Griggs, 40 I U.S. at 426 n.I (citing section 703 as the relevant portion of Title VII); id. at 43 I "The [Civil Rights] Act proscribes not only overt discrimination but also practices that are fair in form, but discriminatory in operation."); id. at 432 (noting that "Congress directed the thrust of the Act to the consequences of employment practices, not simply the motivation").

53 See, e.g., EPSTEIN, supra note 47 , at 197 ; George Rutherglen, Disparate Impact Under Title VII: An Objective Theory of Discrimination, 73 VA. L. REV. I297, 1298 (1987) (claiming that "an extremely strained interpretation" of Title VII is required to "yield an explicit prohibition against neutral practices with adverse impact"). In evaluating whether the Griggs interpretation of section $703(a)(2)$ is a fair reading, it seems reasonable to consider the fact that identical language appears in the Age Discrimination in Employment Act (ADEA). See 29 U.S.C. §623(a)(2) (2000) (making it unlawful for an employer "to limit, segregate, or classify his employees in any way which would deprive or tend to deprive any individual of employment opportunities or otherwise adversely affect his status as an employee, because of such individual's age"). Most courts, however, have declined to read the ADEA to prohibit disparate impact. See, e.g., Ellis v. United Airlines, Inc., 73 F.3d 999, 1007 (Ioth Cir. 1996) (holding that the ADEA does not create a cause of action for disparate impact); DiBiase v. SmithKline Beecham Corp., 48 F.3d 7 19, 732-34 (3d Cir. 1995) (expressing doubts that the ADEA could ever support a disparate impact theory); EEOC v. Francis W. Parker Sch., 4I F.3d 1073, 1076-78 (7th Cir. I994) (holding that the ADEA does not create a cause of action for disparate impact); see also Hazen Paper Co. v. Biggins, 507 U.S. 604, 6 I8 (I993) (Kennedy, J., concurring) (" $[N]$ othing in the Court's opinion should be read as incorporating in the ADEA context the so-called 'disparate impact' theory of Title VII ...."). But see Geller v. Markham, 635 F.2d 1027,1032 (2d Cir. 1980) (holding that the ADEA does create a cause of action for disparate impact). The Supreme Court recently declined to confront the issue. See Adams v. Fla. Power Corp., 255 F.3d I322, 1326 (I Ith Cir. 200I) (holding that the ADEA does not create a cause of action for disparate impact), cert. granted, 534 U.S. 1054 (2001), cert. dismissed as improvidently granted, 535 U.S. 228 (2002).

54 Pub. L. No. 102-166, 105 Stat. 107I.

55 See id. § 105, I05 Stat. at 1074. 
(ii) the complaining party [identifies an adequate] alternative employment practice and the respondent refuses to adopt such alternative employment practice. ${ }^{56}$

Whether anything here amounts to an express classification is a difficult question to answer. Unlike the affirmative action programs in Croson and Adarand, nothing in Title VII names particular racial groups. One might therefore argue that disparate impact doctrine does not make use of express racial classifications, because the statute does not explicitly speak of blacks, whites, Asians, and so on.

Obviously, however, Title VII does instruct state actors to classify people as black, white, Asian, and so on just as if those groups were named in the statute. A plaintiff cannot bring a disparate impact claim without a statistical showing that sorts employees or applicants into groups, and neither the EEOC nor a court can assess a disparate impact claim without deciding whether the classification system the plaintiff used is accurate. ${ }^{57}$ If the substance of an express racial classification is an express command that people be classified by race, then Title VII's disparate impact provision surely qualifies. Drawing a line between statutes that compel the government to decide whether "a particular employment practice ... causes a disparate impact on the basis of race" 58 and statutes that compel the government to decide whether a particular employment practice disparately impacts blacks, whites, Asians, Native Americans, and so on cannot have any strong justification in constitutional theory, unless that theory indulges a formal preoccupation with magic words. ${ }^{59}$

5642 U.S.C. $\S 2000 \mathrm{e}-2(\mathrm{k})(\mathrm{I})(\mathrm{A})$.

57 In the years before Croson and Adarand, lower courts upheld government action that gathered data concerning the racial makeup of workforces. See Caulfield v. Bd. of Educ., 583 F.2d 605, 6ro-I 2 (2d Cir. I978) (upholding a racial census of public school employees); United States v. New Hampshire, 539 F.2d 277, 280-8I (rst Cir. 1976) (upholding the EEOC requirement that state governments provide data on the racial makeup of their public workforces). It should also be noted that it is not only Title VII's disparate impact doctrine that requires government officials to take notice of race. The prohibition on simple intentional discrimination often requires the same. A plaintiff who claims that she was fired for being black is substantially less credible if she is in fact white, and an adjudicating court is not expected to ignore that fact. It is theoretically possible to adjudicate disparate treatment cases without classifying people by race: all that is really required is for the plaintiff to prove that the defendant thought the plaintiff was black, and that could in principle be proved without reference to whether the plaintiff was in fact black. But one should not rest too heavily on this distinction. The plaintiff's race will generally be at least a relevant factor in assessing a claim that she was fired because of her race, if only because it makes her claim more or less plausible.

5842 U.S.C. $\$ 2000 \mathrm{e}-2(\mathrm{k})(\mathrm{I})(\mathrm{A})(\mathrm{i})$.

59 Or unless the problem is that the classification of racial groups in terms of black, white, Asian, Native American, and so on is not the appropriate scheme of classification. But that is beside the present point, which is simply that given a classificatory scheme, there is little substantive difference between saying "use the categories of the scheme" and saying "apply the scheme." 


\section{B. Classification as Normative Conclusion}

It is possible, of course, that equal protection's present preoccupation with classifications is concerned with magic words. That formalism would make some sense, given the Court's stated administrability rationale ${ }^{60}$ and its use of the adjective "express" to describe those classifications that are subject to strict scrutiny. Moreover, some criticism of the Court's "classificationism" 61 seems to perceive the Court as indulging in this kind of formalism. ${ }^{62}$

A better understanding, however, is that the doctrine of express classifications is not in practice about formal statutory language. Often, courts do not approach the question whether a statute uses express racial classifications on formal grounds at all. Instead, the grounds of decision are normative. Rather than deciding whether to apply strict scrutiny simply based upon the presence or absence of certain words, courts often decide whether to apply strict scrutiny based on a normative sense that a statute is constitutionally problematic and then, reasoning backwards, announce that something in the statute constitutes an express classification. ${ }^{63}$ This does not necessarily mean that the courts are deciding the cases wrongly. It may mean instead that "express racial classification" functions as a term of art that encompasses a mix of descriptive and normative elements. ${ }^{64}$ But whether or not this pattern in judicial decisionmaking is correct, it is clear that in practice the question whether government action uses express racial classifications is not one that is answered by checking the text of a government policy against a formal, well-specified definition of such classifications.

Consider, as examples, three cases recently decided by the federal courts of appeals: $M D / D C / D E$ Broadcasters Ass'n v. FCC, ${ }^{65}$ Brown v.

60 See supra pp. 504-06.

61 Jed Rubenfeld, Affirmative Action, to7 YALE L.J. 427, 433 (1997).

62 See, e.g., id. at $433-36$.

63 This pattern by which substantive, nontextual judgments drive courts' conclusions about what is explicit in a text is not unique to racial classifications. See, e.g., Nixon v. United States, 506 U.S. 224, 228-29 (1993) (stating that "the lack of judicially manageable standards [for resolving an issue] may strengthen the conclusion that there is a textually demonstrable commitment [of that issue] to a coordinate branch," thus making the issue nonjusticiable).

64 See Jack M. Balkin \& Reva B. Siegel, The american Civil Rights Tradition: ANTICLASSIFICATION OR ANTISUBORDINATION I I (Issues in Legal Scholarship, The Origins and Fate of Antisubordination Theory, Article No. I I, 2003), at http://www.bepress.com/ils/iss2/art I I (showing that applications of the "anticlassification principle," which prohibits the government from classifying people "either overtly or surreptitiously" on the basis of a forbidden category such as race, have not been formally consistent but have instead tracked different normative evaluations of racial status relationships).

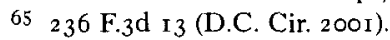


City of Oneonta, ${ }^{66}$ and Raso v. Lago. ${ }^{67}$ In $M D$ Broadcasters, the D.C. Circuit struck down an FCC Equal Employment Opportunity rule that required broadcast licensees to institute employment outreach measures that would, in some cases, have involved reporting the race and sex of each job applicant. ${ }^{68}$ According to the court, the reporting requirement implied that the $\mathrm{FCC}$ would expect any broadcaster whose applicant pool was insufficiently diverse to change its recruiting methods. ${ }^{69}$ The D.C. Circuit regarded this rule as creating government pressure to enhance minority recruitment and hiring, which struck the court as constitutionally problematic racial favoritism. Recruiting resources are finite, the court explained, and requiring that those resources be shifted toward minorities means allocating finite resources in ways designed to benefit members of some racial groups at the expense of others. ${ }^{70}$ The court held that such a racially allocative program violated equal protection. ${ }^{71}$ In the course of so ruling, the court characterized the regulatory scheme as a racial classification subject to strict scrutiny. ${ }^{72}$ On its face, however, the FCC's program merely required the collection of demographic information, much as the census does. The difference between the two cases, and the reason why one attracts strict scrutiny and the other does not, is not a matter of the formal linguistic expressions of the two policies. It is instead a substantive, normative matter: gathering demographic information is not deemed to involve express classification when it occurs in the innocent context of the census, but it is deemed to involve express classification when tied to a racially allocative program. ${ }^{73}$

$66 \quad 22$ I F.3d 329 (2d Cir. 2000).

67 I 35 F.3d I I (Ist Cir. I998).

68 See MD Broadcasters, $236 \mathrm{~F} .3 \mathrm{~d}$ at $\mathrm{I} 7$ (noting that the $\mathrm{FCC}$ rule's option B requires the licensee to report the race and sex of each job applicant); $i d$. at 22 (holding that the rule "violates the equal protection component of the Due Process Clause of the Fifth Amendment").

69 See id. at Í

70 See id. at $20-2 \mathrm{I}$.

71 Id. at 22 ; see also id. at $2 \mathrm{I}$ ("The Commission has designed a new rule under which nonminorities are less likely to receive notification of job openings solely because of their race... The new rule is therefore subject to strict scrutiny for compliance with the constitutional requirement that all citizens receive equal protection under the law.").

72 Id. at ${ }_{5}$ (holding that the FCC rule puts "official pressure upon broadcasters to recruit minority candidates, thus creating a race-based classification that is not narrowly tailored to support a compelling governmental interest and is therefore unconstitutional").

73 It is not surprising that there is a connection among express classifications, strict scrutiny, and legislative motives. Indeed, it is doctrinal orthodoxy that one reason classifications are suspect in the first place is that they raise a presumption of illicit legislative motives. See, e.g., Shaw v. Reno, 509 U.S. 630, 642-43 (I993); Personnel Adm'r v. Feeney, 442 U.S. 256, 272 (I979); Kathleen Sullivan, After Affirmative Action, 59 OHIO ST. L.J. I039, 1046-47 (1998) (noting that "laws that are racially discriminatory in form tend to be presumed racially discriminatory in purpose and effect, and hence subject to strict scrutiny"). What is noteworthy is that the process in cases such as MD Broadcasters seems to operate backwards. Rather than identifying an express 
Whereas $M D$ Broadcasters shows how a court's normative discomfort with government action can motivate it to find an express racial classification, Oneonta demonstrates the inverse proposition: sometimes a court's view that a government practice is reasonable will lead that court to declare that there is no racial classification involved in a government practice that does explicitly categorize people by race. The police in Oneonta, an overwhelmingly white town in upstate New York, responded to a report of a crime committed by a black man by trying to question every black man in or around the town. ${ }^{74}$ The people who were questioned brought an equal protection claim, alleging that the police had used an unjustified racial classification in singling them out. ${ }^{75}$ According to the commonsense understanding of "racial classification" suggested above, ${ }^{76}$ their allegations were factually justified. The police had a description identifying the suspect as black, and they stopped and questioned every black man they could find. ${ }^{77}$ Nonetheless, the Second Circuit concluded that the police had not used an express racial classification. ${ }^{78}$ The official reason for this conclusion was that the plaintiffs "were not questioned solely on the basis of their race ... but also [on the basis of] gender and age, as well as the possibility of a cut on the hand." 79 This is a strange argument. It suggests that what would be a racial classification standing alone is not a racial classification if the racial criterion is combined with nonracial criteria. That cannot be right as a general principle: it seems obvious that a contracting set-aside for young black men with cuts on their hands would get strict scrutiny under Croson and Adarand. The fact that the set-aside would benefit black contractors of a particular age and sex and physical description rather than all black contractors would have no bearing on the constitutional issue. ${ }^{80}$ Less hypotheti-

classification and proceeding to inquire what motivated it, the court forms a view of the motive behind a law and then declares that the law involves an express classification.

74 Brown v. City of Oneonta, 22 I F.3d 329, 334 (2d Cir. 2000).

75 Id. at 337.

76 See supra pp. 505-06.

77 Oneonta, 22 I F.3d at 334. At least one black woman was also questioned. Id. at 338 . Indeed, the plaintiffs' complaint alleged that for a period of five days the police "attempted to stop, question, and physically inspect the hands of any and every non-white person in and around the City of Oneonta." Brown v. City of Oneonta, 235 F.3d 769, 780 (2d Cir. 2000) (Calabresi, J., dissenting from denial of rehearing en banc) (quoting the Second Amended Complaint).

78 Oneonta, 22 I F.3d at 337.

79 Id.

80 The idea that the addition of other factors counteracts classification on the basis of a suspect characteristic appears in at least two other contexts in antidiscrimination law: "sex-plus" cases and university affirmative action cases. In sex-plus cases, judges often decided that discrimination on the combined basis of sex and some other characteristic did not constitute discrimination on the basis of sex because the groups advantaged and disadvantaged by such discrimination did not precisely map the groups "men" and "women." See, e.g., Phillips v. Martin Marietta Corp., 4I I F.2d I, 4 (5th Cir. 1969) (ruling that an employment policy against hiring women with small chil- 
cally, Grutter v. Bollinger ${ }^{81}$ shows that state action using a racial criterion as one factor among several is subject to strict scrutiny for using racial classifications. The state action may survive strict scrutiny if the racial criterion is not too weighty relative to the other criteria, but a racial classification is indeed present and triggers strict scrutiny.

Accordingly, Oneonta raises the question of why a court staffed with intelligent judges would deny the existence of a racial classification in that case. The answer is bound up with the normative reasonableness of using racial descriptions to identify criminal suspects. Believing that such racial descriptions are "altogether legitimate [when based on] ... a physical description given by the victim of a crime," 82 the court wished to avoid a holding that would subject reasonable, ${ }^{83}$ garden-variety police procedures to a strict scrutiny apparatus that almost always results in the invalidation of the examined practice. It therefore decided that the police had not used a racial classification. To be sure, the court could have acknowledged the existence of a racial classification and found that the use of a physical description of a suspect is a compelling state interest that survives strict scrutiny. That analysis would resemble the Supreme Court's opinion in Grutter. But

dren but permitting the hiring of men with small children was not sex discrimination in violation of Title VII), vacated, 400 U.S. 542,544 (I971). The sex-plus idea also appeared in early sexual harassment cases when courts held that harassment was not sex discrimination if it was targeted only at some women rather than all women. "Female and harassed" was thus treated as a multiplication of factors that negated the sex discrimination involved in being disadvantaged simply because one was female. See Reva B. Siegel, A Short History of Sexual Harassment, in DiRections in SEXUAL HaRAsSment LAW (Catharine A. MacKinnon \& Reva B. Siegel eds.) (page proofs at I, 12-13, on file with the Harvard Law School Library) (forthcoming 2003). The harassment version of the multiple-factors construct has been repudiated, but the idea persists in cases involving issues of dress (sex plus a particular grooming style), effeminacy (sex plus behavior), and sexual orientation (sex plus the sex of one's partner). See id. (page proofs at 15 ).

In the affirmative action context, the Court has now held that an admissions policy that uses racial classifications can comply with equal protection if the racial criterion is only one factor among several. See Grutter v. Bollinger, I23 S. Ct. 2325, $2344(2003)$. There is, however, an important doctrinal distinction between this use of the multiple-factors idea and that in Oneonta and the sex-plus cases. Unlike Oneonta, Grutter does not claim that the addition of other factors negates the fact that a racial classification is utilized. Instead, Grutter acknowledges the existence of a classification, applies strict scrutiny, and permits the existence of nonracial factors to inform the result that strict scrutiny reaches.

81 123 S. Ct. 2325 (2003).

82 Oneonta, 22 I F.3d at 337.

83 The substantive judgment that police officers should be able to narrow the field of suspects by questioning only people who physically resemble a witness's description is correct, if bizarrely out of place in a case in which the police seem to have questioned every black male in town. After all, not to narrow a field of suspects by race (or by any other descriptive criterion) would violate the due process rights of obviously innocent people whom police would then question. Consider a case in which the police are told that a short white man held up a gas station and fled on foot. If the police are confident in the description of the suspect but detain and question as suspects persons who do not fit the description - tall people, or nonwhites, or women - they will have abridged those people's liberty without any legitimate basis. 
three years before Grutter, the Second Circuit was loath to choose that course. ${ }^{84}$ Instead, it held that the practice involved no racial classification. ${ }^{85}$

Finally, in Raso $v$. Lago, the First Circuit undermined the idea that racial classifications are formally knowable by advancing the view that whether a particular government action involved racial classification depended on the motives behind it. The case involved a group of three thousand homeowners whose property had been taken by eminent domain as part of an urban renewal plan near downtown Boston. ${ }^{86}$ Massachusetts law required the former homeowners to be given priority in the allocation of rebuilt housing units on the site, but the homeowners were overwhelmingly white, and federal housing regulations under an applicable consent decree required the project to strive for a racial composition reflecting that of the city as a whole. ${ }^{87}$ Boston's population at the time was more than forty percent nonwhite. ${ }^{88}$ As a result, the state preference for former homeowners conflicted with the federally mandated goal of representative racial diversity. Through mediation, the developer, the local agencies, and the Department of Housing and Urban Development (HUD) agreed to apply the preference for prior residents to fifty-five percent of the new housing units and to open the other forty-five percent to all city residents on equal terms. ${ }^{89}$ The prior residents sued, arguing that their collective entitlement to preferences for new units had been compromised based on a racial classification. Had they not been white, they argued, they would have been entitled to priority for all of the new units, not just fifty-five percent of them. ${ }^{90}$

The First Circuit rejected the homeowners' claim. Although the panel majority accepted that the negotiated plan's "purpose [was] to increase minority opportunities for apartments," 91 it maintained that strict scrutiny would not apply unless the government has used a "ra-

84 Both sides in the dispute over whether to rehear the case en banc were self-conscious about this reasoning. See Brown v. City of Oneonta, 235 F.3d 769, 772-73 (2d Cir. 2000) (Walker, C.J., concurring in denial of rehearing en banc) (noting that police work sensibly relies on racial descriptions every day, that the finding of a racial classification would require the application of strict scrutiny, and that strict scrutiny is and should be almost impossible to withstand); id. at 786 (Calabresi, J, dissenting from denial of rehearing en banc) ("The problem is that the strict scrutiny criteria developed by the Supreme Court are much too blunt. If an action is deemed a racial classification, it is very difficult, under the Supreme Court precedents, ever to justify it.").

85 Oneonta, 22 I F.3d at 337. See generally Samuel R. Gross \& Debra Livingston, Racial Profiling Under Attack, 102 COLUM. L. REV. 14I3, I435-36 (2002) (discussing Oneonta).

86 Raso v. Lago, 135 F.3 d I I, I3 (Ist Cir. I998).

87 Id. at I3-14.

$88 I d$. at $\mathrm{I} 4$.

89 Id.

$90 I d$. at 15 .

$91 I d$. at 16. 
cial classification."92 Noting that the forty-five percent of units for which the prior homeowners' preference was overridden were now open to all Bostonians regardless of race, the majority concluded that nothing in the plan could be deemed a racial classification. ${ }^{93}$ But the panel did not stop there. It went on to acknowledge that a different case would be presented if, pursuant to a "secret discriminatory standard,"94 it were only in cases in which the residents of new housing would otherwise be thoroughly white that HUD demanded that housing units be open to members of all races. "That," said the majority, "would be government action based on a "racial classification' . . ."95

What is the constitutional difference between a one-time racially motivated curtailment of the priority for prior homeowners, which is necessary to give effect to a consent decree, and a "secret" and presumably unwritten program of curtailing such priorities only when the affected prior homeowners are predominantly white? The most likely answer is that the need to comply with a valid consent decree is an acceptable reason for HUD to act with a racially allocative purpose. That difference, however, is a difference in motive, not a difference in the operative content of the state's action or in the textual formula describing it. The First Circuit's opinion thus indicates that the question of the existence of a racial classification simply merged with a different and more substantive equal protection issue: government motive. The same state action would be deemed to involve a "racial classification" if it arose from an invalid motive but not to involve a racial classification if the motive behind it was valid.

The moral of this story is that courts' decisions about whether state action uses racial classifications are often tied to their view of the acceptability of the underlying state action. Rather than functioning as a formal means of determining what level of scrutiny should apply, the inquiry into the existence of a racial classification can be directed by normative judgments about motive or other substantive aspects of equal protection such that the classification question does little independent work. This conclusion accords with the critique that current doctrine fails to make consistent sense of the idea that classification is itself a constitutional harm, ${ }^{96}$ and it also explains why the doctrine nonetheless often implies that classification is such a harm: courts find

92 Id.

93 Id at at $16-17$

94 Id. at 17 .

95 Id. One judge dissented, saying among other things that the majority had misread the complaint by construing it to allege only that HUD acted as it did because the plaintiffs were "racially identifiable." According to the dissenting judge, the complaint, when properly construed, did allege that HUD had imposed its demands because the prior homeowners were white. See id. at 19 (Stahl, J., dissenting).

96 See, e.g., Anderson, supra note 40, at $1229-37$. 
classifications in cases in which they have reached the conclusion that something harmful is afoot, but the harmful thing need not be the classification itself.

For the purpose of assessing the constitutionality of disparate impact doctrine under Title VII, it follows that little may be gained from asking whether an express classification is present as if that question could be answered in isolation. Title VII falls into a gray area. The statute evinces a concern with race and implicitly requires state actors to categorize people by race when implementing statutory policy, but it names no racial groups and specifies no differential treatment. Under those circumstances, the ostensibly formal question whether Title VII disparate impact law involves racial classifications is in practice inseparable from the question whether the reallocation of employment positions it requires offends equal protection on more substantive grounds. Therefore, rather than deciding the validity of disparate impact law by reference to whether it uses racial classifications, we must consider how disparate impact looks in light of the substantive themes of equal protection: legislative motive, group treatment, and expressive harm.

\section{LEGISLATIVE MOTIVE}

Determining how equal protection bears on the motive behind Title VII's disparate impact doctrine is a problem with two variables. First, the motive for disparate impact doctrine is subject to several different interpretations. Second, the content of equal protection's concern with motive is unsettled in both doctrine and theory. Figuring out whether disparate impact doctrine has a permissible legislative motive requires grappling with both of these indeterminacies.

Section A of this Part briefly describes what it means to speak of a "motive" behind Title VII's disparate impact doctrine. Section B then reviews several different ways of characterizing that motive. None of these readings maps the statutory doctrine cleanly, but each is plausible, and none is much stronger than the others in terms of the technical or descriptive sense that it makes of the relevant authorities.

As a matter of equal protection law, the choice among these characterizations could be very important. Some of the interpretations focus on employers' present states of mind; such interpretations would be the easiest to defend against an equal protection attack. Accordingly, there is a reason to choose one of them as the motive or motives behind Title VII. ${ }^{97}$ Nonetheless, I believe there are strong normative

97 Indeed, there is more than one reason why this choice might follow. One is the principle that statutes should be construed to avoid constitutional doubt. See Ashwander v. Tenn. Valley Auth., 297 U.S. 288, 346-48 (1936) (Brandeis, J., concurring). In theory, this principle should 
reasons not to abandon the other interpretations, which present the doctrine as aimed at breaking down self-perpetuating segregation and racial hierarchy in the workplace. Section $C$ therefore examines how equal protection would regard these more ambitious motives. It concludes that even after Croson and Adarand, these motives need not trigger strict scrutiny, especially if the racially allocative element of the motive is understood as one value among several that disparate impact doctrine advances.

\section{A. The Need To Construct a Motive}

The constitutional validity of statutes frequently turns on questions of legislative motive. ${ }^{98}$ The problems involved in such an inquiry are familiar: if legislative motive is a function of the objective mental states of legislators, it will often be difficult to determine, and often there will be no single majority motive to be found. ${ }^{99}$ Sophisticated understandings of legislative motive therefore must take "legislative motive" to refer to a construct synthesized from the text, context, operation, and public meaning of the statute. ${ }^{100}$

Even according to this understanding, attempting to determine the legislative motive behind Title VII's disparate impact doctrine poses an unusually difficult problem. ${ }^{101}$ The language of Title VII as origi-

have force regardless of one's normative stance. People who normatively desire to preserve the disparate impact doctrine also have a result-oriented incentive to make this choice.

98 This is true across several fields of constitutional law. See, e.g., Washington v. Davis, 426 U.S. 229, 239-42 (1976) (equal protection); Employment Div. v. Smith, 494 U.S. 872, 877-78 (I990) (free exercise); City of Philadelphia v. New Jersey, 437 U.S. 61 7,624 (1978) (dormant commerce clause).

99 See, e.g., ANTONIN SCALIA, A MATter of INTERPRETATION: FEdERAL CourtS AND THE LAW I6-I8 (I997) (discussing these problems); Frank H. Easterbrook, Statutes' Domains, 50 U. CHI. L. REV. 533, 547-48 (1983) (arguing that problems of agenda-setting can make it impossible to know a legislature's intent even if the full preferences of every individual member could be known); Jeremy Waldron, Legislators' Intentions and Unintentional Legislation, in LAW AND INTERPRETATION: ESSAYS IN LEgAL PHILOSOPHY 329, 336 (Andrei Marmor ed., i 995).

100 See, e.g., Daniel A. Farber \& Philip P. Frickey, Legislative Intent and Public Choice, 74 VA. L. REV. 423, 430-37 (I 988 ) (arguing that public choice theory may provide a more meaningful conception of legislative intent); Donald H. Regan, Judicial Review of Member-State Regulation of Trade Within a Federal or Quasi-Federal System: Protectionism and Balancing, Da Capo, 99 MICH. L. REV. I853, I882-90 (2001).

101 Throughout this Article, I use the word "motive" to refer both to the reasons why a legislature adopts a statute and to the best understanding of what the legislature hopes to achieve with the statute. Some writers have distinguished between these two ideas and used the word "purpose" to refer to the latter one. See, e.g., HENRY M. HART, JR. \& Albert M. SACks, The

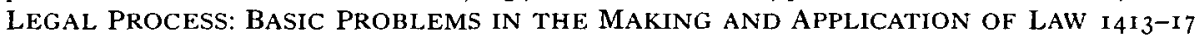
(1958). The relationship between purpose, so defined, and the first sense of "motive" is subtle: one could say that purpose is usually an important component of motive in the more limited sense. I thank Richard Fallon for pressing me on this distinction. In the present Article, I use "motive" in the broader sense, to include both the legislature's reason for acting and the ends at which the statute is imagined to aim. I do so because constitutional inquiries into purpose largely use statu- 
nally passed does noi ciearly create a cause of action for disparate impact, and it is unlikely that the congressional coalition supporting Title VII would have endorsed the disparate impact theory. ${ }^{102}$ Accordingly, an honest appraisal of the I 964 text and context of Title VII could easily conclude that Congress did not intend to prohibit disparate impact at all. As explained in Part I, liability for disparate impact was engineered less by Congress than by the EEOC and the courts. ${ }^{103}$ A court trying to identify the legislative motive behind the prohibition on disparate impact is thus engaged in an interpretive act that is even more hypothetical than normal. It must identify the motive behind a statute, or more precisely an interpretation of a statute, the content of which is less the legislature's creation than the courts' own.

The tail-chasing nature of this exercise is tempered by the fact that Congress sanctioned the disparate impact theory of liability when it amended Title VII in I99I. With minor modifications, those amendments codified the common law of disparate impact as announced in judicial decisions since Griggs. ${ }^{104}$ We can now say that Congress clearly intended in I99 I for disparate impact doctrine to function as laid out in the statute, which provides that a plaintiff may state a claim by making a statistical showing that a particular employment practice causes a disparate impact. The employer can defend the practice by demonstrating that it is "job related ... and consistent with business necessity,"105 and the plaintiff may respond by suggesting an "alternative employment practice" that would achieve the employer's legitimate job-related aims as efficiently as the challenged practice but without causing a disparate impact. ${ }^{106}$ In significant part, this was how disparate impact functioned before I99I as well, but the I99I amendments - now section $703(\mathrm{k})$ of Title VII - make it easier to attribute to Congress a motive to have such a doctrine.

\footnotetext{
tory purpose as an indicator of motive: if a statute's purpose bespeaks an impermissible motive, then the statute is invalid. The aim of the inquiry into purpose, therefore, is the determination of motive, and there is little distance between the two in cases where a statute's purpose is held invalid. In this Part, readers who would like to maintain the analytic distinction between purpose and motive should read questions about the permissibility of Title VII's motive as questions about the permissibility of the motive that the constructed purpose of the statute bespeaks.

102 For a recent thorough treatment of the aims, goals, and limits of that congressional coalition, see Anthony S. Chen, From Fair Employment to Equal Employment Opportunity and Beyond: Affirmative Action and the Politics of Civil Rights in the New Deal Order, I94 I-1972 (2002) (unpublished Ph.D. dissertation, University of California, Berkeley) (on file with the Harvard Law School Library).

103 See supra pp. 506-07.

104 See Civil Rights Act of 1991, Pub. L. No. 102-166, § 3(2), 105 Stat. I071, I07 I (referencing Griggs v. Duke Power Co., 40I U.S. 424 (I97I), and "the other Supreme Court decisions prior to Wards Cove Packing Co. v. Atonio," 490 U.S. 642 (I989)).

10542 U.S.C. $\$ 2000 \mathrm{e}-2(\mathrm{k})(\mathrm{I})(\mathrm{A})(\mathrm{i})(2000)$.

106 See supra pp. 507-08 (discussing section 703(k)). In practice, few litigated cases are decided on the ground that there exists an alternative employment practice.
} 
At the same time, section $703(\mathrm{k})$ leaves a great deal unsettled about the nature of disparate impact actions. The statute does not describe the degree of disparity needed to trigger disparate impact liability, ${ }^{107}$ nor does it describe how "necessary" a practice must be for an employer to defend itself successfully on the ground of "business necessity." The concepts of business necessity and alternative employment device are taken from pre-I99I cases, and section $703(\mathrm{k})$ codifies that common law with all of its attendant uncertainties. ${ }^{108}$

Nor do the I99I amendments resolve ambiguities concerning the purpose of disparate impact law. Instead, they reflect the lack of consensus among those who passed the amendments about the rationale for and contours of the disparate impact standard. ${ }^{109}$ Judicial developments since I99I have not clarified matters: the Supreme Court has yet to construe section $703(\mathrm{k})$. The purpose, meaning, and operation of disparate impact doctrine thus remain a pastiche of statutory fragments and judicial opinions that those fragments may or may not supersede. Given the statute's indeterminacy, whatever court adjudicates a constitutional challenge to disparate impact doctrine must first engage in an act of constructive interpretation to say what the disparate impact standard is and identify the motive behind it.

\section{B. Possible Motives for Disparate Impact Law}

The question, then, is how a reviewing court should understand the purpose of disparate impact law in light of this patchwork of authorities. As noted in the Introduction, there has long been a dispute over whether disparate impact doctrine is an evidentiary dragnet designed to discover hidden instances of intentional discrimination or a more aggressive attempt to dismantle racial hierarchies regardless of whether anything like intentional discrimination is present. ${ }^{110}$ Considered carefully, however, that dichotomy understates the complexity of

107 The EEOC has adopted a working rule under which it will pursue disparate impact cases only when the "selection rate for any race, sex, or ethnic group . . . is less than four-fifths (or eighty percent) of the rate for the group with the highest [selection] rate." 29 C.F.R. $\S$ I607.4D (2002). For a discussion of how disparate an impact must be for there to be a reasonable expectation that a plaintiff can bring a claim under Title VII, see Pamela L. Perry, Two Faces of Disparate Impact Discrimination, 59 FORDHAM L. REV. 523, 570-74 (1991).

108 The I99 I amendments codify the principle of alternative employment practices as it existed on June 4 , 1989, which happens to be one day before Wards Cove was decided. See ${ }_{42}$ U.S.C. $\S 2000 \mathrm{e}-2(\mathrm{k})(\mathrm{I})(\mathrm{c})$. No parallel specification is given for the concept of business necessity.

109 See George Rutherglen, Discrimination and Its Discontents, 8 I VA. L. REV. I I 7 , I 38 \& n.86 (I995) (calling the legislative history of the Civil Rights Act of I99 "as opaque as it is controversial").

110 See, e.g., Belton, supra note 47 , at 224-25 (identifying in disparate impact doctrine "two competing visions of workplace equality," an equal achievement theory and an equal treatment theory); Perry, supra note 107, at 526 (also locating two competing strands of disparate impact doctrine, one focused on fault and the other on effects). 
possible doctrinal purposes. The conception of disparate impact doctrine as an evidentiary dragnet is ambiguous about whether it seeks to discover hidden deliberate discrimination or hidden subconscious discrimination; furthermore, the idea of subconscious discrimination is itself subject to more than one interpretation. The alternative idea, that the doctrine aims to dismantle racial hierarchies irrespective of present intentional discrimination, might mean that it aims to integrate the workplace. But it could also mean, less ambitiously, that it aims to integrate the workplace only to the extent that existing hierarchies can be dismantled through the elimination of irrational business practices. Moreover, the self-perpetuation of hierarchies is often related to subconscious discrimination, such that attempting to separate the two problems risks oversimplification.

This section sorts through these different possible motives for disparate impact doctrine. It begins with the idea of an evidentiary dragnet for hidden deliberate discrimination. It next considers two versions of the idea that the doctrine aims to redress historical hierarchies regardless of the guilt or innocence of present-day employers. Finally, it untangles the idea of subconscious discrimination, showing how different conceptions of that idea partake of elements of each of the two preceding approaches. In the end, none of these options maps the doctrine cleanly. But each is plausible enough to emerge as the official motive of Title VII disparate impact law. ${ }^{111}$

111 In addition to these possibilities, it is worth saying something about another idea in antidiscrimination law that might be thought to correspond to the function of Title VII's disparate impact doctrine but that cannot realistically be claimed as the motive behind it. I refer to the idea that racial disparities in hiring or promotion are not themselves the problem but rather serve as warning signals that the workplace is organized in ways that perpetuate unjustified power structures more generally, not just on the basis of race. In this view, heeding the warning requires reforming workplace dynamics in ways that go beyond alleviating the visible symptom of racial disparity. $C f$. LANi Guinier \& Gerald TORRES, The Miner's Canary: ENLISTING RACE, RESISTING POWER, TRANSFORMING DEMOCRACY I I-12 (2002). The Miner's Canary approach would describe Title VII's disparate impact provisions as follows: If an employment practice has a racially disparate impact, we ask whether the practice is business-justified. If it is, it can continue. But often it will turn out not to be, in which case it must be prohibited. The expected result is that unjustified employment practices will abate and the workplace will become more fair to everyone.

The Miner's Canary idea offers a valuable and provocative perspective on the role of antidiscrimination law, but Guinier and Torres do not claim that it is responsible for Title VII's disparate impact doctrine, and $I$ think they are right not to do so. Although Congress could in principle have employed race as a more tractable means of identifying workers who tend to be victims of social hierarchies, the more straightforward conclusion is that a statute authorizing challenges to employment practices only when those practices have adverse effects on protected classes is concerned not generically with non-business-justified practices but specifically with the racial composition of covered workplaces. An employer whose practices do not have disparate impacts by race, sex, national origin, or religion will escape liability regardless of how non-businessjustified those practices might be. 
I. Evidentiary Dragnet for Deliberate Discrimination. - On this view, disparate impact doctrine is a prophylactic measure that is necessary because deliberate discrimination can be difficult to prove. If liability under Title VII always required proof of deliberate discriminatory motive, a considerable amount of illegal activity would go undetected. Establishing liability for disparate impact addresses this problem by relieving a plaintiff of the need to prove her employer's motive directly as long as the employer's actions create a sufficient pattern of disparate results. ${ }^{112}$ In essence, according to this view, an employer is considered to have intended the systematic results of its practice, so that a pattern of disparate impact raises a presumption of discriminatory intent sufficient to justify imposing liability. ${ }^{113}$ The fact that an adjudicating court does not enter a finding of intentional discrimination does not eliminate the possibility that intent is the doctrine's real concern, because there are potential advantages to enjoining discriminatory practices without branding employers as deliberate racists. Courts may be reluctant to enter such judgments, and employers may be more willing to reform if they are not so accused. ${ }^{114}$

This view of disparate impact law has enjoyed a recent rise in popularity, as courts friendly to disparate impact doctrine have endorsed it in response to the contraction of Congress's Section 5 author-

Moreover, an American legislature seems unlikely to pass a law that addresses racial disparities as symptoms of deeper problems in the distribution of workplace power. From the perspective of the values of private ordering, that argument is significantly more radical than that of Griggs. The Griggs vision calls for unusual measures to be taken in the name of undoing a set of historical wrongs and securing a fair starting point in the competition for employment, but it does not purport to say that traditional employment devices are invalid for all time, under any circumstances. One can accept Griggs without believing that written tests or high school graduation requirements would be problematic in a world without a background of racial hierarchy, such that the sorting functions of those workplace practices did not reinforce the subordination of particular racial groups. Griggs and the I99I amendments to Title VII show that the polity will tolerate some significant inroads on private ordering in pursuit of redressing an extraordinary social problem such as that of racial inequality. It seems unlikely, however, that an American legislature would impose such restrictions in the absence of a concern with discrimination.

112 This idea appears in the legislative history of Title VII: the bill's Senate sponsors submitted an interpretive memorandum explaining that an employer's discriminatory motive could be "best evidenced by his pattern of conduct on similar occasions." I IO CONG. REC. 7214 (1964) (interpretive memorandum of Sens. Clark and Case).

113 This understanding of disparate impact doctrine is reminiscent of the constitutional law idea that strict scrutiny "smokes out" the legislature's true intent. The parallel runs further, inasmuch as the employer's opportunity to demonstrate business necessity is similar to a state's opportunity to show a compelling interest, and the alternative employment practice question is whether there is a less restrictive means. See, e.g., City of Richmond v. J.A. Croson Co., 488 U.S. 469 ( 1989 ) (plurality opinion) (applying strict scrutiny).

114 Cf. Pamela S. Karlan, Two Section Twos and Two Section Fives: Voting Rights and Remedies After Flores, 39 WM. \& MARY L. REv. 725, 735 (1998) (making this point in the voting context); Regan, supra note I00, at I89 (distinguishing protectionism, which courts would not hesitate to find, from racism, which they may avoid finding). 
ity. ${ }^{115}$ Given the post-City of Boerne v. Flores requirement that Section 5 legislation be "congruent and proportional" to the requirements of the Fourteenth Amendment, ${ }^{116}$ disparate impact law stands a better chance of surviving as Section 5 enforcement legislation if its true object is the elimination of deliberate discrimination - which is forbidden by the Equal Protection Clause - than if it embodies a more ambitious policy of social reform. Disparate impact's friends thus have an incentive to take up the evidentiary dragnet theory as a means of preserving disparate impact liability after Boerne.

Nonetheless, there are aspects of disparate impact doctrine that suggest a concern with more than intentional discrimination. For example, the statute now provides that certain defenses available against disparate impact claims are not valid in cases alleging intentional discrimination and that some remedies available in cases of intentional discrimination (notably damages) are not available in disparate impact cases. ${ }^{117}$ These features of Title VII can be read to suggest that disparate impact and intentional discrimination are distinct. ${ }^{118}$

115 See, e.g., Okruhlik v. Univ. of Ark., 255 F.3d 615, 625-26 (8th Cir. 200I); In re Employment Discrimination Litig. Against Ala., I98 F.3d I305, I3I6-I 7 (I Ith Cir. I999). The same tactic appears in Justice Stevens's dissent in Alexander v. Sandoval, 532 U.S. 275 (2001). In response to the majority's argument that Justice Department regulations implementing section $60 \mathrm{I}$ of Title VI could not prohibit disparate impact if section 6or itself prohibits only intentional discrimination, Justice Stevens wrote that a prohibition on disparate impact can be understood as a means of preventing intentional discrimination and therefore as an appropriate implementation of the statutory prohibition. See id. at 306 n.13 (Stevens, J., dissenting).

116 See Boerne, 52 I U.S. 507, 520 (1997) ("There must be a congruence and proportionality between the injury to be prevented or remedied and the means adopted to that end."). Compare Nev. Dep't of Human Res. v. Hibbs, I23 S. Ct. I972, I982 (2003) (upholding a provision of the Family and Medical Leave Act as congruent and proportional to the injury caused by sex discrimination), with United States v. Morrison, 529 U.S. 598, 625-26 (2000) (holding that the civil remedy of the Violence Against Women Act was not congruent and proportional to the requirements of the Fourteenth Amendment), and Kimel v. Fla. Bd. of Regents, 528 U.S. 62, 82-83 (2000) (holding that a portion of the Age Discrimination in Employment Act was not congruent and proportional to the requirements of the Fourteenth Amendment).

117 See 42 U.S.C. $\$ 2000 \mathrm{e}-2(\mathrm{k})(2)(2000)$ (providing that the business necessity defense is unavailable in intentional discrimination cases); id. $\S \mathrm{I} 98 \mathrm{Ia}(\mathrm{a})(\mathrm{I})$ (making compensatory and punitive damages available "against a respondent who engaged in unlawful intentional discrimination (not an employment practice that is unlawful because of its disparate impact)").

118 The distinctions the amended statute draws between cases in which intentional discrimination is shown and cases in which it is not suggest that intentional discrimination continues to be the greater concern. Perhaps the most salient distinction involves the remedies available to successful plaintiffs for each type of claim. Plaintiffs who prove intentional discrimination can recover compensatory and, if appropriate, punitive damages, but plaintiffs who merely prove that an employment practice is unlawful because of its disparate impact are limited to equitable relief. 42 U.S.C. $\S 198 \mathrm{I} a(\mathrm{a})(\mathrm{I})$. This difference cannot be completely explained by the normative idea that employers who discriminate intentionally are morally culpable in a way that employers who for nonracial reasons use employment practices with racially disparate impacts are not. That explanation would make sense as applied to punitive damages. The statute, however, draws the line not between punitive and other damages but between damages of any kind and no damages at 
The I99I Act also allocated burdens of proof in a way that may signal a concern with more than intentional discrimination. During the I 980 , the Supreme Court gave disparate impact plaintiffs the burden of persuasion on the issue of business necessity. ${ }^{119}$ Justices Blackmun and Stevens objected to that allocation. In Watson v. Fort Worth Bank $\mathcal{E}$ Trust ${ }^{120}$ and Wards Cove Packing Co. v. Atonio, ${ }^{121}$ they argued that making the plaintiff prove that a challenged practice was not business-justified was tantamount to making the absence of business justification an element of a disparate impact claim. ${ }^{122}$ That, they argued, was a distortion of the doctrine. In their view, business necessity was an affirmative defense to be proved by defendants after plaintiffs had successfully established the legal injury of disparate impact. Once a disparate impact had been shown, an employer might be excused from liability on a showing of legitimate motive, but no showing at all about the employer's motive was necessary for liability to be imposed. ${ }^{123}$ Congress in I99 I sided with the Wards Cove dissenters, placing the burden of persuasion on the business necessity issue squarely on defendants. ${ }^{124}$ It is not certain, of course, that Congress intended this allocation of the burdens to mean what Justices Blackmun and Stevens said it meant; perhaps Congress simply wished to ease the litigation burden on plaintiffs rather than to redefine the essence of a disparate impact claim. But set against the background of the Blackmun and Stevens opinions, which publicly suggested a particular meaning of the allocation of burdens, Congress's repudiation of Wards Cove on this point could be read as an endorsement of those Justices' theory and, thus, of the view that disparate impact doctrine cares about more than employer motive. ${ }^{125}$

all. There is thus a lingering suggestion that disparate impact without intentional discrimination is not quite the genuine article.

119 See Wards Cove Packing Co. v. Atonio, 490 U.S. 642, 652 (I 989 ) (stating that allocating the burden to defendants would allow "any employer who had a segment of his workforce that was - for some reason - racially imbalanced ... [to] be haled into court and forced to engage in the expensive and time-consuming task of defending the 'business necessity' of the methods used to select the other members of his work force").

120487 U.S. 977 (I 988 ).

121490 U.S. 642 (I 1989 ).

122 See id. at 668-73 (Stevens, J., dissenting); Watson, 487 U.S. at ro00-04 (Blackmun, J., concurring in part and concurring in the judgment).

123 See Wards Cove, 490 U.S. at 669-70 (Stevens, J., dissenting); Watson, 487 U.S. at 100I-04 (Blackmun, J., concurring in part and concurring in the judgment).

$124 \mathrm{See} 42$ U.S.C. $\$ 2000 \mathrm{e}-2(\mathrm{k})(\mathrm{I})(\mathrm{A})(\mathrm{i})(2000)$.

125 Note that the burden at issue here is the burden of persuasion, not the burden of production. When proving a defendant's state of mind is part of what a plaintiff must prove to win his case, it can still make sense to give the defendant the burden of production on the issue of his own state of mind, because the contents of a party's mind are hard for others to discern. It is on this theory that the McDonnell Douglas framework requires employers in disparate treatment cases to produce evidence regarding their motives for employment decisions after the plaintiff has pled a 
There are also less technical reasons to resist the idea that disparate impact doctrine is merely an evidentiary dragnet designed to catch clandestine intentional discriminators. Notably, adopting that idea would erase the theory of Griggs, which remains the fullest statement of the doctrine's rationale. Griggs spoke explicitly about a concern with self-perpetuating racial hierarchies, hierarchies that could persist even in the absence of new discriminatory acts. ${ }^{126}$ As a matter of descriptive interpretation, it is problematic to interpret a doctrine in a way that so thoroughly ignores the fullest (and founding) judicial statement of that doctrine. As a matter of policy, and on the understanding (which I endorse) that the Griggs rationale is normatively desirable, it is problematic to choose an interpretation of Title VII that is wholly about present deliberate discrimination, given that history and de facto segregation remain relevant to the conditions of racial hierarchy in the workplace. To be sure, an honest assessment of the doctrine might require such a reading if Congress had endorsed Wards Cove in I99I. But the 1991 Act is a rejection of the Court's Wards Cove direction. ${ }^{127}$ In short, the theory that disparate impact law is an evidentiary dragnet for deliberate discrimination is neither technically smooth nor normatively desirable. It pays to look for alternatives.

2. Integrating the Workplace. - The theory of disparate impact that is most sensitive to Title VII's role as a remedy for the effects of past segregation justifies liability irrespective of an employer's state of mind. The theory proceeds as follows: As an empirical matter, there is still a significant degree of racial segregation in American employment. ${ }^{128}$ That segregation has historical roots in de jure discrimination, and the old regime continues to have effects. After legal discrimination ended, whites on average still enjoyed better educational and occupational opportunities than blacks, with the result that em-

prima facie case. See McDonnell Douglas Corp. v. Green, 4 I I U.S. 792, 802 (I973). But because a disparate impact claim turns on the defendant's state of mind, and the plaintiff (like any civil plaintiff) bears the burden of persuasion on the ultimate question in a case, see Reeves v. Sanderson Plumbing Prods., Inc., 530 U.S. 133, 143 (2000), plaintiffs in disparate treatment cases must bear the burden of rebutting the defendant's evidence.

126 See Griggs v. Duke Power Co., 40I U.S. 424, 430 (1971) ("Under the [Civil Rights] Act, practices, procedures, or tests neutral on their face, and even neutral in terms of intent, cannot be maintained if they operate to 'freeze' the status quo of prior discriminatory employment practices."). In the constitutional context, Grutter's concern that national leadership cadres be racially integrated shows that the aim of dismantling racial hierarchy continues to animate legal doctrine. See Grutter v. Bollinger, I23 S. Ct. 2325, 2339-41 (2003).

127 See Civil Rights Act of 1991, Pub. L. No. 102-I66, § 2(2), 105 Stat. 1071, 107 I (rejecting Wards Cove).

128 See Anderson, supra note 40, at I199-1200 \& nn.8-19 (describing the statistical degree of racial segregation in housing, education, and employment). Note that employment in many occupational categories is also heavily segregated by sex, albeit not for all of the same reasons. See Christine Jolls, Accommodation Mandates, 53 STAN. L. REV. 223, 293-95 tbl.3 (2000). 
ployers who selected employees based on educational and occupational qualifications tended to hire whites over blacks even if they were not motivated by an intent to discriminate. That pattern can reproduce itself from generation to generation. To the considerable extent that the occupational success of parents shapes the educational and occupational opportunities of their children, and given the low rate of intermarriage between whites and blacks, ${ }^{129}$ applying neutral criteria to haves and have-nots alike could help keep blacks an underclass in the workforce even if employers held no bias in favor of maintaining that state of affairs.

It is for this reason, the theory goes, that the Supreme Court declared in Griggs that Title VII created liability for disparate impact irrespective of employer intent. ${ }^{130}$ Practices that are not required by "business necessity"131 and that are "neutral in terms of intent[] cannot be maintained if they operate to "freeze' the status quo" and permit the legacy of prior discrimination to perpetuate itself. ${ }^{132}$ Adherents to this interpretation thus see disparate impact liability as one of Title VII's mechanisms for ending segregation and racial hierarchy in the workplace - goals identified as the underlying purposes of Title VII in statutory affirmative action cases. ${ }^{133}$ Indeed, under this theory, dispa-

129 See, e.g., Jason Fields \& Lynne M. Casper, U.S. Census Bureau, America's FAMilies aNd Living ARRANGements: POPUlation CharaCteristics i 5 (200I) (stating that in 2000 , only $0.6 \%$ of married couples were black-white), available at http://www.census. gov/prod/200Ipubs/p20-537.pdf.

130 See Griggs, 40 I U.S. at 43 .

131 Id. at $43 \mathrm{I}$.

132 Id. at 430.

133 See, e.g., United Steelworkers v. Weber, 443 U.S. I93, 202-06 (1979) (describing Title VII as primarily concerned with improving the economic situation of African Americans and, therefore, as compatible with affirmative action). It is worth noting that disparate impact doctrine on this view disfavors practices that reinforce historical hierarchies whether or not the condition that causes the disparate impact is a product of past discrimination. In many cases, past discrimination precipitates the condition causing the disparate impact: an easy example is the educational disparity between blacks and whites, brought about by unequal schooling in a segregated system, which produced the disparate impact in Griggs. See Griggs, 401 U.S. at 430 . Sometimes, however, the disparity between historically advantaged and disadvantaged groups is unconnected to the history of discrimination. For example, a significant percentage of African-American men cannot shave because of the effects of a skin condition called pseudofolliculitis barbae. This condition affects a greater proportion of black men than of nonblack men, with the result that workplace rules requiring men to be clean shaven will often have disparate impacts on African Americans. See, e.g., Bradley v. Pizzaco of Neb., Inc., 7 F.3d 795, 799 (8th Cir. 1993). Nobody claims, however, that the history of discrimination is the reason why pseudofolliculitis barbae disproportionately affects blacks. Similarly, disparate impact cases regarding sex commonly concern physical job requirements like height or weight minimums, which disparately exclude women, see, e.g., Dothard v. Rawlinson, 433 U.S. 321, 323-24 (1977), and nobody claims that historical discrimination against women is the reason why women are usually shorter or lighter than men. Nonetheless, because the employment practices in question perpetuate workplace hierarchies that Title VII aims to eliminate, women can use Title VII's disparate impact doctrine to challenge physical 
rate impact law is a cousin of affirmative action. ${ }^{134}$ It is a method of increasing the hiring and promotion of nonwhites (in race cases) and of women (in sex cases). ${ }^{135}$ This parallel raises the question of whether and to what extent such a racially allocative motive opens disparate impact doctrine to the same kinds of equal protection objections that limit the practice of affirmative action.

If "legislative motive" referred either to the actual states of mind of the legislators who passed a law or to the natural and foreseeable consequences of a law, then the intent to break down racial workplace hierarchies by increasing the hiring and promotion of nonwhites might motivate all of Title VII, not just the disparate impact doctrine. The simple ban on intentional discrimination against individuals, known as "disparate treatment," can be understood as a means of racial allocation. ${ }^{136}$ African Americans and members of other disadvantaged groups are the net beneficiaries of a ban on intentional discrimination, and the legislators who passed Title VII understood that this was so. If racially allocative motives raise equal protection problems in the context of affirmative action and disparate impact liability, one might well ask whether such motives also present problems for bans on intentional discrimination. Conversely, if one is confident that there could be no equal protection problem with a law prohibiting intentional discrimination, then perhaps racially allocative motive should not be a serious problem in disparate impact law or affirmative action either.

It may be tempting to argue that an allocative motive is irrelevant where the text and operation of a statute are formally neutral. On its face, Title VII's ban on disparate treatment applies to racial discrimination against anyone, and the doctrine has been construed to protect white plaintiffs as well as nonwhite ones. ${ }^{137}$ Nonetheless, many opponents of Title VII and other Fair Employment Practice laws of its era attacked those measures as affording special treatment to blacks. ${ }^{138}$ In so doing, they looked beyond the formal neutrality of the laws. They

requirements, and black men can use it to challenge shaving requirements. I thank Deborah Malamud for reminding me of the importance of this point.

134 Cf. David A. Strauss, The Myth of Color Blindness, 1986 SUP. CT. REV. 99 (arguing that affirmative action and disparate impact doctrine lie on the same conceptual continuum).

135 Cf. John J. Donohue III, Comment, Understanding the Reasons for and Impact of Legislatively Mandated Benefits for Selected Workers, 53 STAN. L. REV. 897, 905 (2001) ("[T]he disparate impact doctrine was initially conceived as a means of increasing the hiring of women and minorities....").

136 See Owen M. Fiss, A Theory of Fair Employment Laws, 38 U. CHI. L. REV. 235, 313 (1971) (arguing that a key to understanding antidiscrimination prohibitions in the employment realm is that the prohibitions "confer[] benefits on a racial class - blacks"); Strauss, supra note 134, at II I-32.

137 See McDonald v. Santa Fe Trail Transp. Co., 427 U.S. 273 , 280 (1976).

138 See Chen, supra note I02, at I $72-74,183,289-90$. 
understood - correctly - that the major import of formally neutral antidiscrimination laws would be to help African Americans. And rather than seeing that pattern as a consequence of the fact that African Americans were the disproportionate victims of discrimination, they interpreted it as evincing favoritism toward blacks on the part of the government. ${ }^{139}$

In attacking Title VII and other Fair Employment Practice laws as inappropriate racial preferences for blacks, these critics echoed older criticisms of antidiscrimination laws as granting preferential treatment in substance even when neutral in form. A leading early example is the Supreme Court's decision in the $\mathrm{I} 883$ Civil Rights Cases, ${ }^{140}$ which struck down the Civil Rights Act of 1875 . The Act required racial nondiscrimination, but the Court disparaged it for making African Americans "the special favorite of the laws." 141 Blacks were not a "special favorite" in any formal way, because the Act prohibited racial discrimination against people of all races. ${ }^{142}$ But facial neutrality did not insulate the Act from the charge of racial favoritism. The Act was, after all, an attempt to solve a problem that mostly affected blacks, and it was understood as intended to improve the position of a particular racial group.

Today, however, such criticism of facially neutral antidiscrimination laws seems tendentious and farfetched. Such laws are now deeply entrenched within a normative consensus. The issue today is the legitimacy of overt racial preferences, not the legitimacy of antidiscrimination laws that apply to everyone on the same terms. Indeed, those on the conservative side of the current debate base their argument on the rule of general nondiscrimination, which is understood as colorblind rather than racially preferential. ${ }^{143}$

\footnotetext{
139 See id.

140 Iog U.S. 3 (1883).
}

141 See id. at 25 ("When a man has emerged from slavery, and by the aid of beneficent legislation has shaken off the inseparable concomitants of that state, there must be some stage in the progress of his elevation when he takes the rank of a mere citizen, and ceases to be the special favorite of the laws, and when his rights as a citizen, or a man, are to be protected in the ordinary modes by which other men's rights are protected ....”).

142 In relevant part, the Civil Rights Act of 1875 proclaimed:

That all persons within the jurisdiction of the United States shall be entitled to the full and equal enjoyment of the accommodations, advantages, facilities, and privileges of inns, public conveyances on land or water, theaters, and other places of public amusement; subject only to the conditions and limitations established by law, and applicable alike to citizens of every race and color, regardless of any previous condition of servitude.

Civil Rights Act of 1875 , ch. I I 4, I8 Stat. 335,336 .

143 See, e.g., Grutter v. Bollinger, $123 \mathrm{~S}$. Ct. 2325, 2365 (2003) (Thomas, J., concurring in part and dissenting in part) ("Our Constitution is color-blind, and neither knows nor tolerates classes among citizens." (quoting Plessy v. Ferguson, I63 U.S. 537, 559 (1896) (Harlan, J., dissenting))); 
Why, then, are laws against intentional discrimination no longer seen as illicit attempts to improve the position of nonwhites at the expense of whites? One possible answer centers on normative baselines. On the assumption that discrimination is wrongful, any net improvement to the position of nonwhites as a group is merely a corrective that places them in the position they deserve. After all, nonwhites are the disproportionate beneficiaries of the law only to the extent that they are the disproportionate victims of wrongful behavior.

Another reason, however, is that the elimination of intentional discrimination is seen as a legitimate public aim independent of any intent to improve the situation of any given racial group. Given the social consensus condemning intentional racial discrimination, it is easy to imagine a legislature acting on the simple theory that no person should face such discrimination. Indeed, it is assumed that Congress would and should want to eliminate intentional discrimination even if doing so would not change the relative positions of racial groups as a whole. It is therefore easy to deflect the claim that disparate treatment law has an illegitimate purpose, because it is easy to tell a story about a legitimate purpose that could move a legislature to ban disparate treatment.

Disparate impact law is different. It is on its face concerned with the allocation of employment opportunities among racial groups. Moreover, it is hard to think of a non-allocative motive that would prompt Congress to restrict practices with disparate impacts, unless the restriction is merely a means of getting at hidden intentional discrimination. It is possible, as discussed before, to defend disparate impact doctrine by characterizing it as an evidentiary dragnet only. But unless one is prepared to purge Title VII of its responsiveness to history and structural hierarchy, it is hard to characterize disparate impact doctrine as free of racially allocative motives.

One way to test whether disparate impact doctrine is concerned specifically with breaking down the hierarchies that have resulted from the history of discrimination is to ask whether a plaintiff could state a Title VII claim by showing that some employment practice had a disparately adverse effect on a historically privileged class, such as whites in a race case or men in a sex case. If the answer is no, then the doctrine is clearly concerned more with correcting historical imbalances than with combating present prejudice. Disparate treatment claims, we know, are universally available. But there is no authoritative answer to the question whether disparate impact claims are. Commentators are split. Some take the position that members of a

Adarand Constructors, Inc. v. Pena, 515 U.S. 200,239 (1995) (Scalia, J., concurring) (using the colorblindness argument as a reason to oppose affirmative action). 
historically dominant group cannot bring disparate impact claims precisely because practices that adversely affect men or whites as groups do not reinforce workplace hierarchy. ${ }^{144}$ Others take the position that disparate impact claims are universally available. ${ }^{145}$ As a general matter, neither side of this argument cites supporting legal authority both sides seem to assume their answers. Indeed, little authority on the question exists.

What authority there is supports the view that employment practices with disparately adverse impacts on historically dominant classes are, as a matter of law, not actionable under Title VII. The United States Commission on Civil Rights took the position in $198 \mathrm{I}$ that the disparate impact principle "cannot sensibly be applied to white males," because the doctrine is founded on historical and ongoing structures of discrimination against women and nonwhites. ${ }^{146}$ The leading case is Livingston v. Roadway Express, Inc., ${ }^{147}$ which reaches the same conclusion. In that case, the Tenth Circuit ruled that recognizing disparate impact claims brought by whites or men would be contrary to the anti-hierarchy rationale for the existence of disparate impact law in the first place. ${ }^{148}$ To this day, there is no judicial authority contrary to Livingston. ${ }^{149}$ No court, state or federal, has ever sustained a racial

144 See, e.g., Martha Chamallas, Evolving Conceptions of Equality Under Title VII: Disparate Impact Theory and the Demise of the Bottom Line Principle, 31 UCLA L. REv. 305, 366-68 (1983); Donohue, supra note I35, at 898 .

145 See, e.g., Perry, supra note 107 , at 558-59; $c$. EPSTEIN, supra note 47 , at 227 (arguing that whites might have had a Title VII claim in Connecticut v. Teal, 457 U.S. 440 (I982)).

146 See U.S. COMM'N ON CIVIL RIGHTS, AFFirmative ACTION IN THE I980S: DisMANTLING THE PROCESS OF DisCRIMINATION 17 n.20 (I98I).

147802 F.2d I250 (Ioth Cir. I986).

148 See id. at $125^{2}$. Livingston involved a male truck driver who argued that his employer's six-foot, four-inch height limitation for drivers disparately affected men. Id. at I25I. There was no dispute that such a limitation would affect more men than women. See id. The court held, however, that it makes no sense to recognize disparate impact claims in which the alleged victim groups are not groups historically disadvantaged by discrimination, because the aim of disparate impact doctrine, as articulated in Griggs, is to avoid freezing historical inequalities in place. See $i d$. at 1252 . Men or whites could be eligible to bring disparate impact cases if they were historically disadvantaged with respect to the particular jobs at issue: perhaps men could bring such a claim against some practice that disparately disabled men from being nurses or dental hygienists. Cf. $i d$. at $\mathbf{1} 253$ (noting that the majority class plaintiff did not show the defendant to be the "unusual employer who discriminates against the majority"). But the Tenth Circuit held that, in normal circumstances, disparate impact is an asymmetrical doctrine. See id. at 1252 .

149 Few cases presenting the question have been adjudicated, and the major reason is that few facially neutral employment practices have disparately adverse impacts on whites as a racial group or men as a sex. That pattern should not be surprising. After all, a historically advantaged group is almost by definition one that has the education, skills, and other resources necessary to succeed in whatever endeavors a society customarily uses to measure the comparative worth of its members. Thus, courts usually can dismiss the disparate impact claims of white plaintiffs on the grounds that they have failed to show disparate impact as a factual matter. See, e.g., Ratti v. City \& County of San Francisco, 1992 WL 281386 , at *7 (N.D. Cal. Mar. 28, 1992) (granting summary judgment for the defendants because the white male plaintiffs did not make a factual showing of 
disparate impact claim brought by a white plaintiff, nor a sex-based disparate impact claim brought by a man. ${ }^{150}$

One should not lean too heavily on the authority of Livingston, because a single appellate case does not settle a large legal ambiguity. Moreover, Livingston predates Croson and Adarand; after Adarand, courts might be extremely reluctant to hold that a cause of action available to members of some races is not available to everyone. Such a holding would read into Title VII a form of racial discrimination that might invalidate the entire disparate impact doctrine. ${ }^{151}$

Even if courts must hold that disparate impact doctrine is available to whites as well as nonwhites, the rationale underlying Livingston would frame that result as no more than a necessary accommodation

disparate impact), aff $d$, 966 F.2d 532 ( 9 th Cir. 1992); S.-Suburban Hous. Ctr. v. Greater S. Suburban Bd. of Realtors, 713 F. Supp. 1068, 1079-80 (N.D. Ill. 1988) (same, in the fair housing context); Sarvis v. Vt. State Colls., 772 A.2d 494, 501 (Vt. 200I) (noting in dicta that the white male plaintiff failed to offer sufficient factual evidence supporting his disparate impact claim). The courts, therefore, have not reached the question whether a plaintiff who could make a factual showing of a disparately adverse impact on whites or men would state a legal claim.

This is not to say that there are no commonly used employment practices that would have a disparately adverse effect on historically privileged groups. For example, preferences for military veterans in hiring or promotion should be expected to benefit blacks at the expense of whites because the U.S. military for many years has had a higher percentage of blacks and a lower percentage of whites than the population as a whole. Moreover, it seems reasonable to expect that in the coming years, whites as a plaintiff class will be disparately harmed by some kinds of facially neutral practices that have previously operated to their disparate advantage. Notably, in localities with high Asian and Asian-American populations, the written test in some contexts already has had a disparately adverse effect on whites because white test takers do less well on average than Asian and Asian-American test takers. See, e.g., Ho v. S.F. Unified Sch. Dist., 965 F. Supp. I3I6, ${ }_{1319} \&$ n.2 (N.D. Cal. 1997) (describing a pattern whereby students of Chinese descent on average outperformed white students on the criteria - grades and test scores - for admission to Lowell High School, a magnet school).

150 Well, almost. There is, in fact, a single case in which a court has upheld a disparate racial impact claim brought by a white plaintiff, though without addressing the legal question whether such a claim is cognizable. See Craig v. Ala. State Univ., 804 F.2d 682 (I Ith Cir. 1986). The plaintiff in Craig was a white woman, and the defendant was a historically black college that had a practice of filling positions from within its own existing workforce before opening the hiring process to the broader public. See id. at $683-85 \& 685$ n.4. The plaintiff alleged that this practice had an adverse impact on white applicants, and her claim was sustained. See id. at 684-9I. Several aspects of this decision are worth noting. First, the case falls within the exception articulated in Livingston, see supra note 148 , because a historically black institution is a context in which whites may have been historically at a disadvantage in hiring. That was certainly so in this case: the defendant college had previously been adjudged liable for intentional pattern-and-practice discrimination against whites, and the plaintiff's disparate impact claim was part of a suit that originated as a contempt motion for the violation of an injunction entered against the college upon the finding of pattern-and-practice liability. See Craig, 804 F.2d at 683. Furthermore, the Craig court did not discuss the legal question whether a disparate impact claim would be available to white plaintiffs as a general matter. For these reasons, Craig is not authority for the proposition that whites can bring Title VII disparate impact suits as a matter of course.

151 Nonetheless, some commentators maintain that only disadvantaged classes may bring disparate impact claims after Adarand. Donohue, for example, has taken this position as recently as 200 I. See Donohue, supra note ${ }^{3} 35$, at 898. 
to the requirements of equal protection. The policy behind disparate impact doctrine, this interpretation would run, is about combating hierarchy. Equal protection may now require that anyone can state a claim, but that is simply a constraint imposed on how disparate impact doctrine may operate. It does not change the policy that underlies disparate impact liability in the first place. ${ }^{152}$ Unless Congress held the view that employment opportunities should be allocated to people proportionally by race, which we can safely assume is not the case, ${ }^{153}$ it is hard to identify the social harm that occurs when a practice not intended to be discriminatory has a statistically disparate impact on whites.

This approach to disparate impact doctrine is at least as compatible with the web of existing authorities as the evidentiary dragnet theory is. Moreover, it has the normative advantage of acknowledging the relevance of historical discrimination. But it also has weaknesses. First, the Court in cases after Griggs did not hold firmly to Griggs's aggressive view of disparate impact doctrine. On the contrary, it often seemed to retreat toward the less radical evidentiary dragnet theory. ${ }^{154}$

152 In Canada, courts adopt the rationale described in this paragraph when dealing with disparate impact plaintiffs from groups that have not been historically disadvantaged. Canadian constitutional law has adopted a unified standard that merges intentional and adverse impact discrimination into a single framework. See Law v. Canada (Minister of Employment \& Immigration) [1999] I S.C.R. 497 (Can.). Officially, a person of any race (or sex, and so on) could state a claim for discrimination under this framework, but in practice courts interpret the doctrine to limit impact-based claims to those falling adversely on historically disadvantaged groups. Id. Thus, even a system that purports not to draw distinctions between intentional and impact based discrimination claims does not recognize legal harm when a historically dominant group is adversely affected.

153 See 42 U.S.C. $\S 2000 \mathrm{e}-2$ (j) (2000) (disavowing any requirement of proportional hiring).

154 Some decisions spoke of employers' being liable under the disparate impact standard if they had used facially neutral criteria "merely as a 'pretext' for discrimination." Albemarle Paper Co. v. Moody, 422 U.S. 405, 425 (I975) (quoting McDonnell Douglas Corp. v. Green, 4I I U.S. 792, 804-05 (I 973)); see also Wards Cove Packing Co. v. Atonio, 490 U.S. 642, 660-6 I ( 1989 ); Watson v. Fort Worth Bank \& Trust, 487 U.S. 977,998 (I 988 ) (plurality opinion); Connecticut v. Teal, 457 U.S. 440, 447 ( $\left.\mathrm{Ig}^{2}\right)$ (explaining that a disparate impact plaintiff could prevail by showing that a challenged practice, though job-related, was in fact "a mere pretext for discrimination").

The caricature-like facts of Griggs may have helped to undermine the opinion's aggressive stance. The defendant in Griggs, the Duke Power Company, had officially discriminated against blacks until July 2, I965, which happened to be the date that Title VII became effective. Griggs v. Duke Power Co., 401 U.S. 424,427 (I97 I). On that date, the company ceased its official discrimination but adopted a rule that only high school graduates who passed two written aptitude tests could be employed anywhere other than in its lowest wage, lowest status division. Id. at 427-28. These requirements had the effect of preventing all but a few blacks from gaining employment outside the one division where blacks had been allowed before Title VII. Id. at 430 . This tactic was an obvious subterfuge for intentional discrimination. Nonetheless, the district court found as a fact that the company had no discriminatory motive in adopting the high school diploma and written testing requirements. Id. at 428 . The Supreme Court accordingly faced a choice between overturning a factual finding or imposing liability without respect to the defendant's intent, and it chose the latter. Id. at 436; see also Alfred W. Blumrosen, The Law Transmis- 
These developments, which peaked with the r989 Wards Cove decision, convinced many observers that the Court had declawed the disparate impact doctrine except in cases in which the facts suggested hidden deliberate discrimination. ${ }^{155}$ The Civil Rights Act of I99 I explicitly rejected Wards Cove, ${ }^{156}$ thus signaling congressional displeasure with the extent of the Court's conservative retrenchment on disparate impact, but it would read too much into the Act to say that it intended to wipe away everything after Griggs. The language of the statute does not expressly endorse the Griggs theory, and the legislative history cannot be read to do so either. ${ }^{157}$ Second, the idea that disparate impact doctrine is not concerned with employer intentions may be too confident that business necessity is an affirmative defense rather than an integral element of a disparate impact claim. That view of business necessity rests partly on the argument about Congress's allocation of burdens of persuasion in the I99 I Act. ${ }^{158}$ That argument, although analytically tight on its own terms, is not free from doubt, for Congress may have meant merely to increase efficiency without regard to the Blackmun and Stevens dissents. The legislative reallocation of burdens, therefore, does not necessarily signal congressional endorsement of the strong Griggs theory.

But even if the absence of business necessity were integral to a disparate impact claim, it would not follow that we must abandon the view that disparate impact doctrine aims to dismantle workplace hierarchies that reinforce historic discrimination. It would mean only that this view must be refined. Rather than aiming to integrate the work-

sion System and the Southern Jurisprudence of Employment Discrimination, 6 INDUS. REL. L.J. 3I3, 3 I6 (I984) (describing how appellate courts developed legal techniques to overcome Southern factfinders' tendencies to find no intentional discrimination in Title VII and similar cases). Accordingly, although it articulated a more expansive theory, the decision in Griggs was in practice an instance of using disparate impact doctrine to impose liability on an intentional discriminator. But see EPSTEIN, supra note 47, at 193-95 (arguing that the employer in Griggs had no intent to discriminate).

155 See Robert Belton, The Dismantling of the Griggs Disparate Impact Theory and the Future of Title VII: The Need for a Third Reconstruction, 8 YALE L. \& POL'Y REV. 22 3, 237-44 (I990); Barbara J. Flagg, Fashioning a Title VII Remedy for Transparently White Subjective Decisionmaking, I04 YALE L.J. 2009, 2023-24 (1995); Alan Freeman, Antidiscrimination Law: The View from 1989,64 TUL. L. REV. 1407, I428-33 (I990); D. Marvin Jones, No Time for Trumpets: Title VII, Equality, and the Fin de Siècle, 92 MICH. L. REV. 2311, 2345-65 (I 994).

156 See Pub. L. No. 102-166, § 2(2), 105 Stat. I07 I, I07 I.

157 The Act states explicitly that in construing the portions of the statute that relate to disparate impact, the only piece of text that may be considered legislative history is the interpretive memorandum that appears in the Congressional Record. Id. $\$$ I06(b), I05 Stat. at 1075. The memorandum states that the terms "business necessity" and "job related" are intended to carry the meaning attached to them by the Court in Griggs and other decisions prior to Wards Cove. I37 CONG. REC. 28,680 (I99I). The memorandum is silent on the question whether the Griggs definition of "disparate impact" is to be accorded equal deference. Id.

158 See supra p. 522. 
place, perhaps disparate impact doctrine should be understood as aiming only to foster as much integration as would occur if employers stopped using unjustified business practices that reinforced the effects of historical discrimination. On this reading, the doctrine targets not all segregation-perpetuating practices but only those that are not adequately justified by the rational commercial interests of employers. One could support this view of Title VII by noting that an employer could comply with all of the requirements of disparate impact doctrine simply by making sure that all of its employment practices were business-justified. Such an employer would never have to think about disparate racial impacts at all, and Title VII would be satisfied.

This interpretation has the weakness of complexity. It cannot be stated easily in a phrase, and a full sentence statement of the idea sounds like a recapitulation of the entire doctrine rather than a distillation of its essence. At the same time, if by the "legislative motive" behind a statute we mean the hypothesized end that a complex doctrine serves, complexity may be a virtue. After all, perhaps only a complex idea could map a doctrine derived from a patchwork of partially contradictory authorities. And as section $\mathrm{C}$ of this Part shows, this interpretation also may have another advantage over the simpler vision of disparate impact law as aimed at the problem of self-perpetuating racial hierarchy: its more moderate reallocative agenda is more likely to be compatible with modern equal protection.

3. Remedying Subconscious Discrimination. - Between the idea that disparate impact doctrine is concerned with deliberate discrimination and the idea that it is concerned with hierarchy irrespective of employer intentions lies the idea that Title VII is concerned with discrimination that is a function of employers' subconscious states of mind. The idea that much discrimination in contemporary America is subconscious ${ }^{159}$ is perhaps best known to legal audiences from the works of Linda Hamilton Krieger and Charles Lawrence, who have argued that many people who act in biased ways are genuinely unaware of their biases. ${ }^{160}$ Discrimination, on this view, often results from normal psychological dynamics such as the cognitive process of categorization $^{161}$ or the projection of internal neurotic conflict. ${ }^{162}$ According to this perspective, antidiscrimination laws that make deliber-

159 The literature sometimes uses the word "unconscious." I do not here intend my word choice to signify distinctions between the subconscious and the unconscious.

160 See Linda Hamilton Krieger, The Content of Our Categories: A Cognitive Bias Approach to Discrimination and Equal Employment Opportunity, 47 STAN. L. REV. I I6 I, I I64 (I 995 ) (arguing that Title VII jurisprudence is insufficient to address subconscious racial biases); Lawrence, supra note 18 , at 324-26 (arguing that equal protection doctrine should account for subconscious racism by investigating the cultural meaning of government conduct).

161 See Krieger, supra note 160 , at I I 86-88.

162 See Lawrence, supra note I8, at 333-34. 
ate intent a necessary element for imposing liability will systematically fail to reach the problem because there may be no conscious discriminatory intent to discover. Some courts therefore have pointed to subconscious discrimination as a reason for using impact standards. ${ }^{163}$

The idea that disparate impact doctrine is concerned primarily with subconscious discrimination shares important features with the theory of the doctrine as an evidentiary dragnet for deliberate discrimination. Both readings are concerned with the defendant's mental state, whether that be the deliberate intent to discriminate or the subconscious tendency to do so. Both accounts read Title VII to allow a pattern of discriminatory results to substitute for a direct showing of discriminatory intent, acknowledging the difficulty of proving mental states. Moreover, and unlike the strong Griggs theory of disparate impact, both views are concerned with discrimination in the present. The shared traits of the subconscious and deliberate discrimination theories suggest that they should be considered two versions of the view that disparate impact doctrine is an evidentiary dragnet for present acts of discrimination. On this view, the underlying premise that supports prohibiting subconscious discrimination is that conduct derived from subconscious discriminatory attitudes is wrongful in a way analogous to the way in which deliberate discrimination is wrongful. ${ }^{164}$

The position that disparate impact doctrine seeks to remedy subconscious discrimination suffers from some of the same drawbacks as the position that disparate impact doctrine is a means of ferreting out deliberate discrimination. Subconscious discrimination, like conscious discrimination, is a function of the defendant's mental state. If a defendant's mental state is not part of the plaintiff's case-in-chief after the I99 I amendments, then plaintiffs should not have to prove defendants' subconscious mental states any more than their conscious ones. More importantly, this theory of subconscious discrimination continues to neglect the historical and structural aspects of disparate impact liability. For reasons like those articulated in Griggs, de facto hierarchies are likely to perpetuate themselves even in the absence of subconscious discriminatory attitudes among contemporary employers. A theory of disparate impact that turns only on present attitudes - con-

163 See, e.g., Watson v. Fort Worth Bank \& Trust, 487 U.S. 977, 990 ( I 988) (plurality opinion) (noting that "even if one assumed that [intentional] discrimination can be adequately policed through disparate treatment analysis, the problem of subconscious stereotypes and prejudices would remain" if there is not also a disparate impact standard); In re Employment Discrimination Litig. Against Ala., I 98 F.3d I 305, 132 I (I Ith Cir. 1999) (citing Watson, 487 U.S. at 990, and Lawrence, supra note 18 , for the proposition that impact standards serve to detect subconscious discrimination).

164 Compare this view with Part IV on the revelatory approach to expressive harm, according to which we sometimes care about the attitude that an action reveals. 
scious or not - obscures the continuing role of historical discrimination in shaping employment opportunities.

But the preceding approach to subconscious discrimination misses some of the nuance that the subconscious discrimination perspective might offer. First, the law seems to regard the subconscious discriminator as less culpable than the deliberate discriminator. For instance, damages are available under Title VII only for intentional discrimination, not conduct based on subconscious biases. ${ }^{165}$ Also, subconscious discrimination can be unrelated to historical hierarchies: people can act on subconscious aversions to members of other demographic groups even when no actual hierarchy corresponds to the aversion. ${ }^{166}$ At other times, though, historical hierarchy and subconscious discrimination are interrelated. White employers may react adversely to nonwhite employees or applicants without realizing that their adverse reaction flows, in whole or in part, from a subconscious racial distaste rooted in historical hierarchy. Also, and more systemically, one form of subconscious discrimination is the undervaluing of members of a particular group, which both entrenches and increases tolerance of those groups' low rates of success.

Suppose that white employers learn to expect most blacks to be poorly educated. It would be natural for those employers to be unsurprised and unconcerned if only a few blacks held skilled employee positions. The employers may assume, without much reflection, that the racial pattern they observe is the result of relevant skill differentials rather than an artifact of the employee selection process. Accordingly, the employers will have little impulse to investigate whether that assumption is correct or whether they could modify their hiring and promotion processes in ways that would increase workplace integration. And if the employers do not wonder why their workforces tend toward racial segregation, the existing hierarchies are likely to persist. The conditions of those hierarchies will then continue to foster the subconscious undervaluing of the groups that occupy its lower rungs: people will continue to think - accurately, in a statistical sense - of members of the disadvantaged groups as likely to be uneducated, antisocial, and ultimately unqualified. The power of the subconscious stereotype thus helps perpetuate the hierarchy from which the stereotype arose.

If subconscious discrimination is conceived along these lines, then combating subconscious discrimination is not only a present-oriented

165 See supra note I 18

166 In one famous survey of attitudes toward members of minority ethnic groups, many respondents professed aversions to three nonexistent groups — the Dariens, the Praneans, and the Wallonians - that were included in the survey. Obviously, no actual hierarchy subjugates members of these groups. See Lawrence, supra note I 8 , at 332. 
project concerned with employers' states of mind. It is also an attempt to stop the self-perpetuation of inherited hierarchies. "Preventing subconscious discrimination so as to impede the perpetuation of hierarchy" is, after all, a subset of "preventing self-perpetuating hierarchy, even when caused by actions or practices not intended to discriminate." Adopting this view of subconscious discrimination thus rescues the subconscious discrimination theory of disparate impact law from the charge that it ignores the role that historical or structural aspects play in some of the doctrine's sources. By forcing employers to notice racial patterns and think about possible ways to change them, disparate impact doctrine helps diminish the power of historical hierarchies.

Even so, the subconscious discrimination rationale does not supply a clean account of the motive behind Title VII's disparate impact doctrine. Subconscious discrimination remains a matter of an employer's state of mind, and the allocation of the burden of proof on the issue of business necessity continues to cast doubt on the possibility that the employer's state of mind lies at the core of a disparate impact claim. ${ }^{167}$ Perhaps more substantively, subconscious discrimination is not the only mechanism for the transmission of hierarchy. Even if Title VII is read as aimed at redressing wrongful workplace hierarchies, nothing in the statute suggests that it targets only those hierarchies whose perpetuation can be traced to present subconscious discrimination. ${ }^{168}$ In summary, the idea of subconscious discrimination creates more perspectives from which to understand the possible motives for disparate impact law, but it does not supply an account of a single motive that maps all of the doctrine's features. Instead, it breaks down along lines that partially reproduce - though perhaps in more nuanced ways the competing roles of historical hierarchy and present states of mind within the rubric of disparate impact law.

4. Choosing a Motive. - As one might expect from a doctrine with polyglot origins, no single theory makes sense of all of the data. The statutory text is sketchy, and the cases speak in more than one voice. Nonetheless, constitutional evaluation of disparate impact doctrine requires choosing a particular account as the best understanding of its purpose. Making such a choice is partly a matter of mapping the

167 See supra p. 522

168 It is possible, of course, to collapse all of the ways in which hierarchy can perpetuate itself into the category of "subconscious discrimination" simply by saying that any employer who permits the self-perpetuation of racial hierarchy in his or her workplace is acting in a subconsciously discriminatory way. But that move collapses any distinction between the subconscious discrimination paradigm and the redressing hierarchy paradigm. It is then difficult to understand what benefit there is in speaking of subconscious discrimination as a separate approach to disparate impact doctrine (except, perhaps, that the use of the word "discrimination" conveys a stronger normative implication of wrongfulness than is present in an approach that regards disparate impact law as prohibiting even "innocent" actions that perpetuate the hierarchy). 
various strands of authority and partly a normative decision about what makes the doctrine valuable. Normative considerations aside, none of the available options - evidentiary dragnet for deliberate discrimination, workplace integration, or remedy for subconscious discrimination - is so much more coherent or persuasive than the others that it emerges as the clear choice. But as a normative matter, an account that emphasizes breaking down historical hierarchy and persistent segregation is preferable to presentist readings that focus on the employer's state of mind.

\section{Applying Equal Protection to Title VII's Motive}

I. Focusing on the Harder Question. - The theories of disparate impact doctrine that are concerned with employers' states of mind do not raise equal protection problems on account of their animating motives. ${ }^{169}$ Put simply, equal protection prohibits intentional discrimination; thus, under accepted equal protection doctrine, there is nothing objectionable about an animating motive to prohibit intentional discrimination. Indeed, a statute aimed at improving the mechanisms for prohibiting intentional discrimination could itself be regarded as legislation enforcing equal protection. ${ }^{170}$ Because equal protection's understanding of intentionality is confined to deliberate, conscious intentions, a statute aimed at prohibiting subconscious discrimination would probably not qualify as legislation enforcing equal protection. Nevertheless, so long as the statute sought to prohibit subconscious discrimination against anyone, rather than to protect certain specified groups, the motive behind the statute would also not violate equal protection - at least as long as the aim of prohibiting subconscious discrimination is understood to be about banning present wrongful actions rather than redressing historical hierarchies. ${ }^{171}$

In contrast, legislation intended to break down inherited racial hierarchies and to integrate the workplace is at greater risk of being found to have an unconstitutional motive. Such motives are racially allocative. They aim to change the racial mix of people getting jobs

169 This is not to say that state of mind theories of disparate impact raise no equal protection problems at all. It means only that whatever problems might arise do not stem from issues of legislative motive. Potential problems associated with group treatment and expressive harms could still remain. See infra Parts III and IV.

170 See, e.g., Okruhlik v. Univ. of Ark., 255 F.3d 6I 5, 626-27 (8th Cir. 200I) (holding that Title VII's disparate impact standard is valid enforcement legislation under Section 5 of the Fourteenth Amendment because it furthers the Fourteenth Amendment's prohibition of intentional discrimination).

171 Nothing here is intended to deny that disparate impact doctrine conceived of as an evidentiary device for reaching either deliberate or subconscious discrimination might not, as a subjective matter, be motivated by the desire to provide net assistance for disadvantaged racial groups at the expense of whites. See supra pp. 525-27. 
and promotions, increasing the proportion of jobs and promotions won by members of certain racial groups at the inevitable expense of people from other groups. ${ }^{172}$ Cast in that light, disparate impact doctrine is a conceptual cousin of affirmative action. To be sure, disparate impact doctrine differs from affirmative action in important ways that might make the doctrine easier to defend from constitutional attack, even if its motive is the same. Nevertheless, construing the motive behind disparate impact law as racially allocative creates tension with equal protection as currently interpreted.

Because disparate impact doctrine is less constitutionally problematic as a device for addressing deliberate or subconscious discrimination than as a device for affirmatively integrating the workplace, supporters of the doctrine might choose to construe it as having the former purposes only. That strategy would seem to avoid the problem. But from a normative perspective, adopting those readings of disparate impact doctrine would sacrifice much of what makes the doctrine worth saving. De facto hierarchical racial segregation remains a reality in many workplaces. Moreover, that segregation perpetuates itself: the theory that normal patterns of behavior will reproduce the hierarchy from generation to generation is today complemented by statistical studies that evince an enduring problem of racial segregation across a range of contexts. ${ }^{173}$ Rather than abandon a reading of the doctrine that tries to grapple with that social problem, it seems worthwhile to seek ways to save it. Similarly, characterizing disparate impact law as a means of smoking out the knowingly wrongful behavior of particular defendants would advance the trend whereby the law of discrimination is increasingly severed from its historical context - a trend that should be resisted for normative reasons as well as for reasons of intellectual clarity. Thus, although disparate impact doctrine could be saved from an equal protection challenge by limiting its ken, the more valuable (albeit more difficult) project is to try to save the doctrine while permitting it to retain its concern with history, hierarchy, and integration.

2. The Problem: Racially Allocative Motives. - To the extent that disparate impact law seeks to dismantle inherited racial hierarchies, disparate impact and affirmative action laws share a common motive. A major difference between the two kinds of laws, however, is that disparate impact doctrine does not use express racial classifications in

172 When this Article speaks of reallocating employment opportunities to members of one group at the expense of members of another group, the baseline against which "reallocation" and "expense" are measured is simply the status quo without the particular reallocative mechanism of the disparate impact doctrine. I do not mean to imply anything about the justice or propriety of that baseline.

173 See Anderson, supra note 40, at I $200-02$ \& nn.15-24. 
the way that affirmative action does. As explained in Part I, the question whether Title VII's disparate impact doctrine uses racial classifications is complex and possibly unanswerable in the absence of an overall normative judgment about its policy. In contrast, Adarandstyle affirmative action does not fall into a gray area. It is clearly classificatory and therefore provokes strict scrutiny. ${ }^{174}$

Laws that do not use express racial classifications can still violate equal protection if motivated by illicit discriminatory intentions. ${ }^{175}$ Suppose, for example, that the California state legislature passed a law cutting property taxes in mostly white Beverly Hills and raising them in mostly black South Central Los Angeles, and suppose further that the law was found to have been motivated, in whole or in part, by the intent to shift the tax burden from whites to blacks. Under Village of Arlington Heights v. Metropolitan Housing Development Corp., ${ }^{176}$ a showing that discriminatory intent was a motivating factor would subject the law to strict scrutiny. ${ }^{177}$

Title VII's disparate impact doctrine may come under the rule of Arlington Heights. Even if deemed a facially neutral law rather than one that uses express racial classifications, it would be - on the interpretation here considered - a law with a racially allocative motive and therefore subject to strict scrutiny under Arlington Heights. To be sure, Title VII has a different racially allocative motive from the one alleged in Arlington Heights or the one in the taxation hypothetical directly above. Rather than aiming to burden a historically disadvantaged group, it aims to redress self-perpetuating patterns of racial hierarchy inherited from a time of de jure discrimination. In the context of affirmative action, that difference has been called the difference between benign and malign intentions. ${ }^{178}$ And after Adarand, the claim

174 See Adarand Constructors, Inc. v. Pena, 5 I 5 U.S. 200, 227 (I995).

175 Consider, for example, the proposition that government may not act out of sheer animus toward any group. See Romer v. Evans, 5 I 7 U.S. 620, 635 ( I 996) (striking down a Colorado state constitutional amendment that prohibited all state action designed to protect homosexual persons from discrimination); City of Cleburne v. Cleburne Living Ctr., 473 U.S. 432, 447-50 (1985) (finding that a law requiring a home for the mentally retarded to obtain a special-use permit violated equal protection). Presumably, an animus-based law would be invalid regardless of whether it used express classifications. See, e.g., City of Richmond v. United States, 422 U.S. 358, 378 (I 975 ) ("An official action ... taken for the purpose of discriminating against Negroes on account of their race has no legitimacy at all under our Constitution . . ."); Guinn v. United States, 238 U.S. 347 , 364-65 (I9I5) (striking down a facially neutral but racially motivated amendment to Oklahoma's constitution).

176429 U.S. 252 (1977).

177 Adarand, 5 5 U.S. at 265-66, 270 n.2 I. Discriminatory motive can be hard to demonstrate, but that is a problem of proof rather than a question of the constitutional status of a law whose motivation has been demonstrated. See id. at 266-68 (setting forth factors that might help demonstrate discriminatory motive).

178 See, e.g., id. at 275 (Ginsburg, J., dissenting). 
of a benign intention cannot insulate a facially classificatory law from strict equal protection scrutiny. ${ }^{179}$

Facially neutral laws may be different. Even after Adarand, the Arlington Heights rule may be sensitive to the content of a legislature's racially allocative motive. No case has held that racially motivated but facially neutral laws are always subject to strict scrutiny even if the racial motivations are those that might once have been characterized as "benign," meaning that they are intended to benefit rather than burden members of historically disadvantaged racial groups. The holdings of Croson and Adarand are carefully confined to cases involving express classifications, and dicta leave open the possibility that the Arlington Heights situation is distinguishable. ${ }^{180}$ Thus, a racially motivated law cutting taxes in South Central Los Angeles while raising them in Beverly Hills might escape strict scrutiny even though the inverse law would not.

I do not say that this difference is a matter of established doctrine. Just as no case has held that reverse Arlington Heights laws are subject to strict scrutiny, no case has held that they are not. Both possibilities exist. There is also a third possibility, which is that reverse Arlington Heights laws are subject to strict scrutiny but could survive it. Which of these possibilities is the best understanding of the law is a debatable question, as is the question of which possibility will be borne out in the course of future judicial decisionmaking (and these two questions are not the same). Given that Title VII's disparate impact doctrine might be categorized as a facially neutral law intended at least in part to improve the position of traditional victim groups, these questions are worth pursuing.

3. A Way Out: "Alternative Action." - Perhaps the strongest reason to think that Arlington Heights does not apply to facially neutral but racially motivated laws intended to benefit disadvantaged groups comes from dicta in several cases discussing the choice between using "race-neutral means" and facially classificatory affirmative action to improve the position of minorities. ${ }^{181}$ Instead of setting aside a certain

179 See Adarand, 5 I5 U.S. at $225-27$.

180 See id. at 213 ("We note, incidentally, that this case concerns only classifications based explicitly on race, and presents none of the additional difficulties posed by laws that, although facially race neutral, result in racially disproportionate impact and are motivated by a racially discriminatory purpose." (citing Arlington Heights)). To be sure, some of the Justices perceived Adarand to rest on a more sweeping principle. See, e.g., id. at 240 (Thomas, J., concurring) ("[T]here is a 'moral [and] constitutional equivalence[]' . . . between laws designed to subjugate a race and those that distribute benefits on the basis of race in order to foster some current notion of equality." (alteration in original) (quoting $i d$. at 243 (Stevens, J., dissenting))). But Adarand's holding concerns only classifications.

181 See, e.g., Adarand, 515 U.S. at 237-38; City of Richmond v. J.A. Croson Co., 488 U.S. 469, 507 ( 1989 ) (plurality opinion). 
percentage of contracting business for minority-owned contractors, the Croson Court wrote, the city of Richmond could have modified its municipal contracting practices in other ways that, without making race itself a factor in awarding individual contracts, would have increased contracting opportunities for minority contractors otherwise likely to be excluded. ${ }^{182}$ For example, Richmond could have subsidized all new contracting firms, relaxed its bonding requirements, or provided training for disadvantaged contractors of all races. ${ }^{183}$ To whatever extent minority-owned contractors were disproportionately represented among disadvantaged contractors, such race-neutral measures would disproportionately benefit minority contractors, thus increasing minority contracting without any need to prefer some contractors to others on the basis of race. ${ }^{184}$

Adarand repeated this idea that "race-neutral means to increase minority business participation" 185 can be a constitutionally appropriate substitute when race-specific affirmative action programs would violate equal protection. ${ }^{186}$ And in Grutter v. Bollinger, ${ }^{187}$ which sustained a facially classificatory program, the Court implied that a raceneutral program aimed at the same end would also have been constitu-

\footnotetext{
182 See Croson, 488 U.S. at 509-10.

183 See id. at 507, 509-10.

184 See id.; see also id. at 526 (Scalia, J., concurring).

185 Adarand, 5 I 5 U.S. at 238 (quoting Croson, 488 U.S. at 507).

186 See id. at 237-38. Adarand relied on Croson's description of this idea, and Croson in turn articulated the idea of race-neutral remedies prefigured in United States $v$. Paradise, 480 U.S. 149, I 7 I (1987), and Fullilove v. Klutznick, 448 U.S. 448, 5 10 (1980). See Croson, 488 U.S. at 507. But the discussion of such measures in Paradise and Fullilove was in a different context. In Paradise, the issue was the propriety not of a legislative affirmative action program but rather of a racially classificatory remedy ordered by a federal court after a finding of illegal discrimination. See Paradise, 480 U.S. at 153 . The possibility of race-neutral remedies was raised as a way of determining how necessary the race-conscious court order was, see id. at I $7 \mathrm{I}$, though the Court suggested that a race-conscious order might be justified even in circumstances where a raceneutral remedy was possible. See id. at I84. In Fullilove, which did present the question of the validity of a legislative affirmative action program, Justice Powell wrote that in reviewing Congress's use of race-conscious remedies for discrimination, it was instructive to note the criteria that federal appellate courts had used for reviewing quota-based discrimination remedies issued by district courts. Fullilove, 448 U.S. at 5 Io (Powell, J., concurring) (citing NAACP v. Allen, 493 F.2d 6I4, 6 I9 (5th Cir. 1974); and Vulcan Society of the New York Fire Department, Inc. v. Civil Service Commission, 490 F.2d 387, 398 (2d Cir. 1973)). One of those criteria, Powell noted, was the efficacy of alternative remedies. Id. Powell did not conclude, however, that Congress could use race-conscious remedies only when no alternatives were available. On the contrary, he specified that his approval of the Fullilove set-aside did not depend on a finding that other methods had been unavailable to Congress. See id. at 515 n.14. Thus, if Croson and Adarand imply that Congress may not use racially classificatory affirmative action in cases where race-neutral means are available, they promulgate a regime more restrictive of congressional means than that articulated in Paradise and Fullilove.
}

$187 \quad 123$ S. Ct. 2325 (2003). 
tional, indeed more safely so than the program at issue. ${ }^{188} \mathrm{Kim}$ FordeMazrui has promoted the term "alternative action" as a shorthand for the kinds of race-neutral actions the Court had in mind. Forde-Mazrui defines alternative action as "the pursuit of affirmative action objectives, such as remedying past discrimination or promoting racial diversity, through policies that rely on race-neutral means, such as needbased preferences." 189 I will use this term.

An alternative action law is an Arlington Heights law in reverse. It is, by hypothesis, a law motivated by the desire to allocate something to one or more racial groups at the inevitable expense of others. This racially allocative motivating factor would subject such a law to strict scrutiny under Arlington Heights if whites were the benefited group and the burdened group were a historically disadvantaged one. Thus, to say that such a law escapes strict scrutiny is to say that equal protection still recognizes a distinction between benign and malign discriminatory motives, even after Adarand. ${ }^{190}$ Nonetheless, many opponents of traditional affirmative action have endorsed alternative action as a constitutionally satisfactory substitute. ${ }^{191}$

Probably the best-known alternative action program is the "Texas Ten Percent Plan" for college admission. ${ }^{192}$ In 1996, the Fifth Circuit barred public universities in Texas from using explicit affirmative action in admissions decisions. ${ }^{193}$ Nonwhite enrollment predictably declined. In response, Texas instituted the Ten Percent Plan, which guarantees admission to the University of Texas to any student who graduates in the top ten percent of a Texas high school. ${ }^{194}$ Given that

188 See id. at 2345 ; see also id. at 2374 (Kennedy, J., dissenting) (arguing that courts should "force educational institutions to seriously explore race-neutral alternatives"); $c f$. Gratz v. Bollinger, I23 S. Ct. 24I I, 2430-3I (2003) (holding a classificatory program unconstitutional). In the future, perhaps such race-neutral means will replace classificatory affirmative action.

189 Kim Forde-Mazrui, The Constitutional Implications of Race-Neutral Affirmative Action, 88 GEO. L.J. 233 I, 2335 (2000).

190 Grutter confirms that equal protection does sometimes recognize such a distinction during the application of strict scrutiny. See Grutter, 123 S. Ct. at 2347 . The present question is whether there might be such a distinction as part of the decision about whether strict scrutiny is the appropriate standard to apply.

191 See Forde-Mazrui, supra note i 89 , at 2349 n.75.

192 Two recent studies provide detailed analyses of the Texas Ten Percent Plan, its effects, and its relationship to other percentage plans across the country. See CATHERINE L. HORN \& STella M. Flores, The Civil RIGHTS ProjeCt AT HARVARD UNIV., PERCENT PLANS IN COLlEge AdMISSIONS: A COMPARATIVE ANALYSIS OF THREE STATES' EXPERIENCES I4I9 (2003), http://www.civilrightsproject.harvard.edu/research/affirmativeaction/tristate.pdf; U.S. Comm'n on Civil Rights, Beyond Percentage Plans: The Challenge of Equal OPPORTUNITY IN HIGHER EDUCATION (2002), http://www.usccr.gov/pubs/percent2/percent2. pdf.

193 Hopwood v. Texas, 78 F.3d 932, 934 (5th Cir. 1996).

194 Forde-Mazrui, supra note I89, at 2332-33. See generally GUINIER \& TORRES, supra note I I I, at 67-72 (describing the evolution of the Texas Ten Percent Plan, beginning with the Hopwood decision). After the Supreme Court's ruling in Grutter superseded Hopwood, the University 
de facto residential segregation causes many Texas schools to be heavily black or Latino, the Ten Percent Plan leads to the admission of many more black and Latino students than would be admitted without the plan. The intent of the Ten Percent Plan, just like the intent of classificatory affirmative action, is to increase minority enrollment. ${ }^{195}$ Nonetheless, many opponents of classificatory affirmative action have endorsed the Ten Percent Plan. ${ }^{196}$

The Tenth Circuit upheld another form of alternative action in Byers v. City of Albuquerque. ${ }^{197}$ The Albuquerque police department administered a written test as part of its promotions process and announced before the test was given that the top thirty-five scorers would proceed to the next stage of the process. ${ }^{198}$ After tabulating the results of the test, department officials decided to increase the number of officers who advanced to the next stage of the process to fortytwo. ${ }^{199}$ The officers who benefited from this change were disproportionately female, nonwhite, or both. ${ }^{200}$ The Tenth Circuit assumed without deciding that the change was made for racially motivated reasons, ${ }^{201}$ but it nonetheless rejected an equal protection challenge brought by white male officers. The court noted that all candidates were given the same test regardless of race, that all of the tests were scored in the same way, and that no candidate passed with a score lower than that of the highest-scoring rejected candidate - in sum, that the competitive playing field was level. ${ }^{202}$ The motive for the

of Texas announced that it would resume considering race as a factor in admissions. See Greg Winter, Ruling Provides Relief, but Less Than Hoped, N.Y. TIMES, June 24, 2003, at A23. It remains to be seen whether the Ten Percent Plan will be retained now that race will also be considered directly.

195 See Gratz v. Bollinger, ${ }_{2} 3$ S. Ct. 24 I I, $244^{2}(2003)$ (Souter, J., dissenting) ("The 'percentage plans' are just as race conscious as the point scheme."); GUINIER \& TORRES, supra note II I, at 67-74 (illustrating how the development of the Texas Ten Percent Plan was driven by the desire to increase minority enrollment); Forde-Mazrui, supra note 189 , at 2332.

196 See, e.g., Brief for the United States as Amicus Curiae Supporting Petitioners at $\mathrm{I}_{4}, \mathrm{Gratz}$ (No. 02-5 I6) (noting the successes of the Texas Ten Percent Plan).

197 I 50 F.3d 227 I (1oth Cir. 1998).

198 Id. at $\mathrm{I} 273$.

199 Id.

200 See id.

201 Id. at 1276 ; see also id. at 1274 (discussing a memorandum stating that the change was made "for affirmative action reasons").

202 Id. at $\mathrm{x} 276$. The Tenth Circuit's statement that nobody was placed at a competitive disadvantage because of his or her race is true in the static sense that each possible cutoff score was administered in a race-neutral way. Viewed dynamically, the question is more complicated. Even in a system where cutoff scores are adjusted to capture larger numbers of nonwhites, it is not necessarily the case that a white candidate has a smaller probability than a nonwhite candidate of being in the group captured by the change. Imagine that 70 white candidates and 30 black candidates take a police promotions test for which the initially stated passing score is 80 points. Assume that 30 white candidates and 3 black candidates score higher than 80 and that 15 more white candidates and 6 more black candidates have scores between 75 and 79 . A department 
change was to alter the demographic mix of the successful candidates, but the means chosen - lowering the cutoff score - was facially and formally race-neutral and therefore was found to be consistent with equal protection. ${ }^{203}$

Given that the motives behind alternative action are the same as the motives behind classificatory affirmative action, it pays to ask why alternative action is not subject to the same constitutional analysis as affirmative action. ${ }^{204}$ One possible answer, of course, is that in fact it is. Perhaps the dicta in Croson, Adarand, and Grutter are merely dicta; perhaps, were the question presented, the Court would disavow those dicta and reject lower court rulings like Byers. But if there is an answer that vindicates the pro-alternative-action dicta, it must include the proposition that the motives behind classificatory affirmative action alone do not provoke strict scrutiny. If they did, then the motives of alternative action would provoke strict scrutiny as well. And it

seeking to increase the proportion of promotions that go to black officers might well lower the cutoff score to 75 , thereby increasing the percentage of blacks among the successful candidates from $9 \%$ ( 3 out of 33 ) to I $7 \%$ ( 9 out of 54 ). Nonetheless, the change in cutoff score cannot be said to have put white candidates at a disadvantage compared to black candidates, because on these figures each initially unsuccessful white candidate had a greater chance of benefiting from the change than each initially unsuccessful black candidate. (The probability for whites is 15 out of the 40 initially unsuccessful white candidates, or $37.5 \%$; the probability for blacks is 6 out of 27 , or $22 \%$.) To be sure, there will also be cases in which increasing the proportion of successful candidates who are minorities will mean expanding the successful pool in ways that give minority candidates a greater probability than whites of being the beneficiaries of the change. Either scenario is possible, depending on the numbers in a particular case.

The one respect in which lowering a cutoff score will predictably work to the competitive advantage of minority candidates is that the decisionmaking authority will be unlikely to lower the score in a way that captures a white candidate (or a male candidate in a sex case) last. In the example given above, one would guess that the department would be much more likely to lower the cutoff score one more point to 74 if the single candidate who scored 74 points were black than if he were white.

203 Another example, and perhaps one that pushes a bit farther, involved a police entrance exam administered in Nassau County, New York. See Hayden v. County of Nassau, 180 F.3d 42, 46 (2d Cir. 1999). The test had 25 sections that could be scored independently. Id. at 47 . It was not necessary to include all 25 sections to come up with a statistically valid test result; valid results could be obtained by using any of several different combinations of sections. (For example, it might be equally valid, ex ante, to calculate candidates' scores based on their performances on sections I through Io or based on their performances on sections i i through 20.) After the test was given, the test administrators examined the results by section and sought to assemble a combination of sections that would yield statistically valid results while minimizing the adverse impact of the test on African-American candidates. Id. at 47. They settled on a particular combination of 9 sections, rejecting one other combination that yielded a better result for African Americans but was less statistically valid. Id. A group of white and Latino applicants brought an equal protection challenge, which the Second Circuit rejected. Id. at 46 . Like lowering the cutoff score in Byers, the scoring method approved in this case could be described as a facially race-neutral means of increasing minority success.

204 Justice Souter's dissent in Gratz implies that it should be. See Gratz v. Bollinger, i23 S. Ct. $24 \mathrm{II}, 2443$ (2003) (Souter, J., dissenting) (commenting that "[ $t$ ]he 'percentage plans' are just as race conscious as the point scheme"). 
would also follow that affirmative action programs of the kind at issue in cases like Croson and Adarand are problematic for reasons related not to their motives but to their means of operation.

There are several ways in which affirmative action programs could be problematic for reasons other than motive. One possibility is that classification is itself a constitutional harm. ${ }^{205}$ Another possibility is that the process of administering classificatory affirmative action programs involves the disfavored practice of state officials' treating particular individuals differently on the basis of race. ${ }^{206}$ A third possibility is that some combination of the first two factors gives rise to problems of expressive harm, whether by evincing illicit legislative attitudes toward race or communicating disfavored ideas about race to the wider public. ${ }^{207}$

Alternative action avoids the first two problems and mitigates, if not quite avoids, the third. Laws like the Ten Percent Plan and onetime acts like lowering the cutoff score in Byers do not use racial classifications in the open way that Adarand-style affirmative action does. Government officials do take note of race during the process of deciding what plan to institute, but that kind of classification falls into the gray area that will be overlooked if the plan as a whole seems tolerable. ${ }^{208}$ Once the plan is in place, it can be administered by officials who never even know the race of the candidates. And because the visibility of race in the decisionmaking process is reduced in both of the foregoing ways, alternative action is less likely than classificatory affirmative action to generate expressive harms (that is, unless it becomes publicly understood that the rules of admission have been changed in order to admit more people of particular racial groups, in which case the plan's race-consciousness may also contribute to a sense that the plan uses "racial classifications" ${ }^{209}$ ). If some combination of such considerations is sufficiently powerful, then the Court's

205 See supra Part I. But see, e.g., Anderson, supra note 40, at 1229, 1234-47 (critiquing this view as incoherent).

206 See infra Part III (discussing group treatment).

207 See infra Part IV (discussing expressive harms). As Part IV explains, there is a dispute in the literature as to which of those two theories - evincing illicit legislative attitudes or communicating disfavored ideas - is properly called "expressive harm."

208 See supra Part I on classification as a normative conclusion.

209 The rise of such a widespread public understanding may be one consequence of the publicity surrounding Grutter and Gratz, because the function and purpose of such plans were prominently discussed in the media before the cases were decided as well as in the Court's opinions. See, e.g., Gratz, I23 S. Ct. at 2440-4I (Souter, J., dissenting); id. at 2445-46 (Ginsburg, J., dissenting); Adam Cohen, Why the Supreme Court Needs To Visit Cass High School, N.Y. TIMES, Mar. 3I, 2003, at A12; Richard Cohen, Diversity at What Cost?, WASH. POST, Apr. 3, 2003, at A23. Thus, the "public meaning" of measures like the Ten Percent Plan may be different today from what it was in 2002 . See infra Part IV on expressive harms and public meaning. 
dicta about race-neutral means could be vindicated, and alternative action could be exempt from the rule of Arlington Heights.

4. Limits: "Predominant Motive." - Even if some alternative action laws could escape strict scrutiny, there must be constitutional limits on government's license to act for the purpose of reallocating goods from historically advantaged racial groups to historically disadvantaged ones, even when the means for pursuing those motives are themselves unobjectionable. For example, a decision to raise taxes in Beverly Hills and lower them in South Central Los Angeles would probably be invalid if it were based on simple racial animus toward whites. ${ }^{210}$ The question, then, is how to distinguish acceptable motives of racial reallocation from unacceptable ones.

The cases dealing with race-based electoral districting may supply an answer. According to the Supreme Court, racially motivated districting plans like those at issue in Shaw v. Reno and Miller v. Johnson are facially neutral. ${ }^{211}$ An electoral district discriminates on its face only by geography, not by race. The equal protection issue concerns the motives behind how a district is drawn. ${ }^{212}$ Under Miller, strict scrutiny applies if racial motives were the predominant motives behind a districting plan. ${ }^{213}$ Note that this is a different standard from the one articulated in Arlington Heights. According to Arlington Heights, strict scrutiny is triggered if allocating goods from one racial group to another is a motivating factor behind a law. ${ }^{214}$ Miller's standard is significantly more deferential to the legislature. Where it applies, a showing that racial allocation was a motivating factor is not sufficient to trigger strict scrutiny, ${ }^{215}$ even though such a showing would trigger strict scrutiny under Arlington Heights.

What distinguishes Miller from Arlington Heights? One possibility is that equal protection behaves differently in different substantive

210 See Romer v. Evans, 517 U.S. 620, 635-36 (1996) (holding that anti-homosexual animus is a prohibited basis for legislation); City of Cleburne v. Cleburne Living Ctr., 473 U.S. 432, 450 (1985) (holding the same in regard to animus against the mentally retarded).

211 See Miller v. Johnson, 515 U.S. 900, 913-14 (1995) (analyzing a racially motivated districting plan as a facially race-neutral measure); Shaw v. Reno, 509 U.S. 630, 644-46 (1993) (same); $c f$. Gerken, supra note 16 , at $1695-96$ (arguing that Shaw and similar cases are about facially neutral measures that benefit minority groups).

212 See Miller, 5 I 5 U.S. at 9I I-I 3; Shaw, 509 U.S. at 645-47; $c f$. Richard H. Pildes, Principled Limitations on Racial and Partisan Redistricting, I06 YALE L.J. 2505, 2505-09 (1997) (describing and criticizing this motive-based approach).

213 Miller, 5 15 U.S. at 916.

214 See Vill. of Arlington Heights v. Metro. Hous. Dev. Corp., 429 U.S. 252, 265-66 (1977).

215 See Easley v. Cromartie, 532 U.S. 234, 257 (2001) (declining to apply strict scrutiny after concluding that race was not the predominant motive behind the creation of an electoral district); Bush v. Vera, 5 i 7 U.S. 952, 985 (1996) (O'Connor, J., concurring) (stating that what equal protection prohibits in the redistricting cases is the "unnecessary and excessive governmental use and reinforcement of racial stereotypes" (emphasis added)) 
contexts, such that the rules applied in voting cases may not apply in housing cases. ${ }^{216}$ Another answer, however, is that Arlington Heights states a rule for laws intended to burden members of historically disadvantaged groups, and Miller states a rule for laws intended to benefit such groups. The district challenged in Miller was drawn for the purpose of electing a black representative, not a white one. ${ }^{217}$ In such a case, a racially allocative motive might provoke strict scrutiny only when that motive eclipses all others and becomes predominant. In a case where the intent to discriminate against African Americans was a

216 See Ellen D. Katz, Reinforcing Representation: Enforcing the Fourteenth and Fifteenth Amendments in the Rehnquist and Waite Courts, I0I MiCH. L. REV. (forthcoming June 2003) (noting ways in which equal protection operates differently in the voting context from in other areas); Daniel R. Ortiz, The Myth of Intent in Equal Protection, 4I STAN. L. REv. IIO5, IIO7 (1989) (arguing that the application of equal protection standards varies depending on whether the case concerns housing, employment, juries, voting, or school desegregation). As it happens, however, the specific patterns that Katz and Ortiz illustrate do not account for the specific difference between Miller and Arlington Heights. Ortiz shows that the Court's variation of the rules of proof in equal protection cases operates to police the government's conduct more vigilantly when political liberalism "insists on particular types of nonmarket allocation (as in voting, jury selection, and sometimes education)." Id. Accordingly, the Court should have applied equal protection more aggressively in Miller, a voting case, than in Arlington Heights, a housing case. See id. at I $_{10}$, I I 40. But in fact, the Court articulated a more deferential approach in Miller than in $A r$ lington Heights. Ortiz is correct that equal protection analysis sometimes varies with the substantive context, but the particular variance at issue here requires other explanations.

Similarly, Katz shows a pattern of judicial deference in voting cases reviewing congressional legislation passed under the Reconstruction Amendments but not in voting cases reviewing state or local legislation. See Katz, supra. Miller concerned a districting plan drawn by the state of Georgia, not by Congress, Miller, ${ }_{115}$ U.S. at $907-08$, and the more deferential approach to strict scrutiny that it articulates therefore cannot be attributed to the fact that it is a voting case. Again, other explanations are required for the difference between Miller and Arlington Heights. This does not mean, however, that Katz's and Ortiz's more general point that voting cases may elicit different rules is not correct. Race may pervade the redistricting process to such a degree that a strict scrutiny review of all districts drawn with race as a consideration would be unworkable. See Samuel Issacharoff \& Pamela S. Karlan, Standing and Misunderstanding in Voting Rights Law, I I HARV. L. REV. 2276 , 2292 (1998).

${ }^{217}$ Miller, 5 I5 U.S. at 908-09. Considered carefully, it requires further argument to show that majority-minority districting can be accurately described as benefiting the minority group. Respectable arguments can be made for the proposition that majority-minority districting is a form of "packing" that limits a minority group's political influence. Such districting enables the election of representatives of that group, but those representatives may then be isolated and impotent in a legislature that is not responsive to their agendas. See David Lublin \& D. Stephen Voss, The Partisan Impact of Voting Rights Law: A Reply to Pamela S. Karlan, 50 STAN. L. REV. 765, 768 (1998). This may especially be true when, as with the Shaw district, majority-minority districting is part of a program that works to the net benefit of the political party other than the one of which the minority legislators are members. At the same time, there may be benefits to the relevant minority group from such an arrangement even if the political party of which they are members suffers. See id. at 767-68 (arguing that majority-minority districting in the I 990 os benefited Republicans and African Americans at the expense of white Democrats). For the moment, I assume the validity of the core intuition that majority-minority districting is a form of affirmative action, intended to benefit the relevant minority group. 
motivating factor in the drawing of a district, strict scrutiny might apply under the principle of Arlington Heights.

Although existing case law neither confirms nor disproves this explanation, ${ }^{218}$ it seems like a reasonable hypothesis, especially when one considers that there is a more general pattern in antidiscrimination law whereby reviewing courts determine the dominance of a given motive. In Grutter and Gratz, for example, the validity of the University of Michigan's affirmative action plans turned substantially on the relative importance of the racial criterion for admission as compared to other admissions factors. Where the Court found race to be predominant, it disallowed affirmative action. ${ }^{219}$ Where it found the racial motive to be merely one factor among several, the Court permitted affirmative action. ${ }^{220}$ In a slightly different vein, one might also think of Title VII's statutory mixed-motive regime, which distinguishes between cases in which invidious discrimination is shown to be a motivating factor in an employment decision and cases in which that factor rises to the importance of but-for causation. ${ }^{221}$ Thus, even if special considerations relevant to voting cases mean that the model suggested here would not apply in that area, Miller's idea that equal protection looks differently on moderate and extreme degrees of racial motive could still help make sense of how alternative action could escape strict scrutiny. The following scheme results for challenges to facially neutral government action:

218 There are no cases in which the Court has found that the intent to discriminate against African Americans was a partial but non-predominant motivating factor in the drawing of an electoral district.

219 See Gratz v. Bollinger, I23 S. Ct. 2411,2428 (2003).

220 See Grutter v. Bollinger, I23 S. Ct. $2325,2343-44(2003)$. The difference between Gratz and Grutter on one hand and districting or disparate impact cases on the other is that the affirmative action plans in Gratz and Grutter were facially classificatory and therefore already subject to strict scrutiny. See Gratz, I23 S. Ct. at 2427 ; Grutter, I23 S. Ct. at 2337-38. In those cases, rather than determining the type of scrutiny to be applied, the dominance of the racial motive relative to other factors determined whether the program could survive strict scrutiny.

221 See 42 U.S.C. $\$ 2000 e-2(\mathrm{~m})(2000)$; see also Desert Palace v. Costa, I23 S. Ct. 2148,2152 (2003) (holding that the district court properly instructed the jury that "[i]f you find that the plaintiff's sex was a motivating factor in the defendant's treatment of the plaintiff, the plaintiff is entitled to your verdict... unless the defendant proves by a preponderance of the evidence that the defendant would have treated plaintiff similarly even if the plaintiff's gender had played no role in the employment decision" (internal quotation marks omitted)). 


\begin{tabular}{|c||c|c|}
\hline \multirow{2}{*}{$\begin{array}{c}\text { Direction of } \\
\text { Racial Motive }\end{array}$} & \multicolumn{2}{|c|}{ Degree of Racial Motivation } \\
\cline { 2 - 3 } $\begin{array}{c}\text { Harms } \\
\text { Disadvantaged } \\
\text { Group }\end{array}$ & $\begin{array}{c}\text { Strict scrutiny } \\
\text { (or invalid per se) }\end{array}$ & $\begin{array}{c}\text { Strict scrutiny } \\
\text { (Arlington Heights) }\end{array}$ \\
\hline $\begin{array}{c}\text { Helps } \\
\text { Disadvantaged } \\
\text { Group }\end{array}$ & $\begin{array}{c}\text { Strict scrutiny } \\
\text { (Miller) }\end{array}$ & $\begin{array}{c}\text { Deferential scrutiny } \\
\text { (alternative action) }\end{array}$ \\
\hline
\end{tabular}

For this scheme to explain the constitutionality of alternative action, devices like the Texas Ten Percent Plan and the reduced cutoff score in Byers would have to treat racial allocation as a motivating factor but not as their predominant motive. The argument in support of this proposition would be that the selection criteria in each case demonstrate that the selection process is not concerned with race above all else. The Texas plan still rewards success in high school, and the Byers device still uses the written test as a significant sorting tool. If those nonracial criteria are as important as the racial ones to the overall selection process, then racial allocation may not rise to the level of a "predominant motive," and strict scrutiny may not be triggered. These characterizations resemble the formula in the districting cases: racial motive can be acceptable as long as it does not eclipse other, "traditional" criteria for drawing electoral districts. ${ }^{222}$ Similarly, universities can prefer members of racially disadvantaged groups as long as the value of the racial preference is, inter alia, not too large as compared to the value of other admissions criteria. ${ }^{223}$

The foregoing analysis shows how the motive behind disparate impact doctrine could avoid triggering strict scrutiny, even if that doctrine aims to eliminate de facto racial hierarchy in the workplace by reallocating positions from some racial groups to others. As noted above, Title VII's disparate impact standard can be understood as a

222 See Miller, 5 I 5 U.S. at 916. "Traditional" is placed in quotation marks because the implication that nonracial districting factors such as political and geographical borders are part of a continuous historical practice in American politics is misleading. Prior to the Supreme Court's imposition of the "one person, one vote" rule, many states had conducted no redistricting in more than fifty years. Regular redistricting began only after the Court's decision in Reynolds $v$. Sims, 377 U.S. 533 (1964). See Pamela S. Karlan \& Daryl J. Levinson, Why Voting Is Different, 84 CAL. L. REV. I 20I, I 206-07 (I996).

223 See Gratz, I23 S. Ct. at 2428; Grutter, I 23 S. Ct. at 2343-44. 
facially neutral rule with a racially allocative motive. ${ }^{224}$ On that understanding, its equal protection status should be the same as that of alternative action laws. As long as the racially allocative element of Title VII's motive does not predominate over other aspects of the statutory purpose, disparate impact doctrine should be able to avoid strict scrutiny in the same way as the Texas Ten Percent plan and the police program in Byers.

We now may have another basis for choosing among the different versions of Title VII's integrationist motive. Recall from section B of this Part that the motive behind Title VII's disparate impact doctrine can be seen as eliminating self-perpetuating racial hierarchies, period, or as eliminating only non-business-justified practices that contribute to such hierarchies, or as eliminating inherited hierarchies only to the extent that the mechanism of their perpetuation is present subconscious discrimination. On the first vision, the only - and therefore predominant - motive behind disparate impact law is racial reallocation. On the latter two visions, the reallocative motive is limited from its inception by either a competing desire to let employers hire, fire, and promote based on criteria of economic efficiency, or a complementary desire to prohibit employment decisions based on wrongful states of mind. Therefore, it might be plausible to characterize Title VII's racially reallocative motive not as a predominant consideration to which all else must bend, but rather as one significant factor in a policy that also honors other and more anodyne values.

There are weaknesses in both of these portrayals of disparate impact law as a facially neutral measure in which the racial motive is not predominant. Consider first the version on which the reallocative motive is limited by, and does not predominate over, allowing employers to pursue economically rational policies. Whether this characterization of disparate impact doctrine could avoid strict scrutiny would depend on the meaning of "predominant motive." If a predominant motive is a motive so powerful that it sweeps all other values before it, then tempering the reallocative motive with the business necessity defense might succeed in preventing the reallocative motive from being "predominant." But there is another plausible understanding of "predominant motive," according to which the sine qua non of the state action in question - the motive for which the law exists at all - is its predominant motive.225 And there can be no question that the concern with race (and other forms of discrimination) is the sine qua non of Title VII. The University of Texas would still have an admissions rule,

\footnotetext{
224 See supra section II.C.2, pp. 537-39.

225 These two understandings of "predominant motive" can exist simultaneously, in the disjunctive: a motive might be predominant if it either is so powerful as to sweep all other values before it $o r$ is the sine qua non of the law in question.
} 
the Albuquerque police department would still give sergeant's exams, and the states of Georgia and North Carolina would still draw electoral districts even if a concern about the relative success of people from different racial groups were no part of the picture. When that concern is introduced, it can enter in a limited way that does not overwhelm the set of criteria on which those decisions would have otherwise been made.

In contrast, disparate impact liability is part of a law that would not exist at all but for the concern with race. Even if the statute concedes a significant role to considerations of instrumental business rationality, it would be disingenuous to say that Title VII is motivated partly by racial concerns and partly by economic efficiency concerns. Title VII does not seek to force employers to be economically efficient against their will: except where issues of racial discrimination are concerned, employers remain perfectly free to send themselves into bankruptcy through bad business decisions. ${ }^{226}$ Title VII's animating purposes are not flouted when businesses do poorly. Instead, the role of the business necessity idea in disparate impact doctrine is simply to limit the race-oriented restrictions that Title VII imposes on covered employers. Accordingly, even though disparate impact doctrine recognizes other values that limit its concern with race, the racial motive might still be predominant. ${ }^{227}$

As a matter of securing a permissible predominant motive, it may be slightly safer to construe the motive behind disparate impact law as to target subconscious discrimination. Banning employment decisions that are based on wrongful discriminatory motives is constitutionally unproblematic. If a subconsciously discriminatory state of mind is wrongful, one could argue that disparate impact doctrine does not violate the Equal Protection Clause because the doctrine is predominantly motivated by the desire to prevent the inherent wrong of subconscious discrimination. The desire to stop the perpetuation of racial hierarchies may play a role in the doctrine, but it is a subsidiary motive.

226 It may be the case, however, that in practice Title VII systematically pushes employers toward functional justifications for their decisions and therefore toward instrumentally rational behavior. See Robert Post, Prejudicial Appearances: The Logic of American Antidiscrimination Law, 88 CAL. L. REV. I, I3-I6 (2000) (making this argument with respect to employment discrimination law).

227 Indeed, instead of regarding disparate impact doctrine as having two motivating factors, one of which is about race and one of which is about business efficiency, it might be more accurate to regard it as having one motive and one limitation on the scope of the doctrine. The limitation acts as a narrow-tailoring device, like a time limit on a traditional affirmative action plan. Such a limitation does not alter the motive, nor does it excuse the plan from strict scrutiny. Instead, it increases the likelihood that the plan will survive strict scrutiny. Cf. Grutter, I $33 \mathrm{~S}$. Ct. at $2327-28,2346-47$ (applying strict scrutiny to a race-based affirmative action program but upholding it, in part because of assurances that it would be time-limited). 
This solution also has downsides. First, the concern with history and hierarchy is demoted here even farther than in the moderated version of the integrationist motive, described just above, in which disparate impact doctrine aims to integrate the workplace to the extent that integration can be achieved by eliminating irrational business practices. Second - and more practically - this solution requires reviewing courts to say that defendants who lose disparate impact suits are not merely liable but also wrongful discriminators. As noted earlier, courts may be more willing to enjoin employers' practices if they can do so without branding the employers as holding wrongful racial attitudes. Moreover, employers may cooperate more willingly if they do not feel that they have been identified as racists. ${ }^{228}$ Prefacing the accusation with the qualifier "subconscious" may not do much to change either of those two dynamics. Accordingly, disparate impact doctrine has something to lose by being construed in a way that would characterize liable defendants as wrongful actors. One advantage of the other versions of the integrationist motive is that they permit those defendants to retain the status of relative innocents, guilty of nothing more than imposing a level playing field. These understandings of Title VII make a finding of disparate impact a less inflammatory move for the judge to make, a less bitter pill for the defendant to swallow, and a more realistic goal for the plaintiff to pursue.

\section{Summation of Motive Issues}

No account of Title VII's motive accounts cleanly for all of the authorities that compose the disparate impact doctrine, and the choice between state-of-mind interpretations and interpretations more concerned with historical hierarchies or structural segregation is largely a normative matter. Choosing the state-of-mind interpretation would be one way to stay on the safe side of equal protection. This choice could be motivated either by a desire to save that which can be saved of disparate impact liability or simply by the principle of judicial craft whereby statutes should be construed to avoid constitutional difficulties. For reasons of normative policy and historical fidelity, however, the latter set of disparate impact theories should not be abandoned lightly. Giving them up would forfeit one of the few remaining legal prompts for thinking about continuing problems of racial hierarchy in employment. It would also erode awareness that present hierarchies are largely the product of past discrimination and that those hierar-

228 See Karlan, supra note $\mathrm{I}_{\mathrm{I}} 4$, at 735 ("If [judges] are compelled to call their acquaintances evil in order to do justice, then they may find themselves tempted to shade their judgment in even remotely close cases."); Regan, supra note I00, at I891 (suggesting that a court would be reluctant to accuse a local school board of racism). 
chies can renew themselves without the intervention of new, willfully malevolent acts.

It may not matter whether disparate impact doctrine's raceconscious anti-hierarchy motive is presented as complete in and of itself or as tempered by respect for economic rationality. On one reasonable understanding of the difference between "motivating factors" and "predominant motives," the racially allocative aspects of Title VII's motive are predominant even if the business necessity defense shows that the doctrine is also respectful of other values that limit that allocative aim. If that analysis applies, then the motives behind disparate impact doctrine are likely to trigger strict scrutiny. It bears remembering, however, that the law of alternative action is severely underdeveloped. ${ }^{229}$ It is possible that even a predominantly raceconscious motive would be sustainable in a properly structured alternative action plan; it is also possible that courts would interpret "predominant" to mean not the motive without which the doctrine would not exist but rather a motive so powerful that it sweeps all other values before it. On the latter reading, disparate impact doctrine could escape strict scrutiny while still embodying a concern with selfperpetuating racial hierarchy. It would do so on the understanding that disparate impact doctrine aims at nothing more or less than eliminating those unnecessary business practices that reinforce historically wrongful segregation. Finally, disparate impact doctrine might survive motive analysis on a subconscious-discrimination theory, but that survival might come at the cost of both partially submerging the concern with hierarchy and forfeiting the doctrine's ability to coerce workplace change without leveling accusations that sound in racism. These are the choices. They are free of neither compromise nor uncertainty.

\section{INDIVIDUALISM AND GROUP TREATMENT}

The difference between seeing Title VII's disparate impact doctrine as an evidentiary dragnet designed to discover evidence of deliberate discrimination and seeing it as a means of integrating the workplace is partly about the difference between seeing it as concerned with the rights of individuals and seeing it as concerned with the status of groups. It is important not to apply these categories woodenly, because the rights of individuals and the status of groups are intertwined rather than mutually exclusive. ${ }^{230}$ When a group has systematically

229 See supra section II.C.3, pp. 539-45.

230 See Gerken, supra note 16 , at $1669-89$ (showing that the legal rights of individuals sometimes depend on the treatment of a group); $c f$. J.M. Balkin, Nested Oppositions, 99 YALE L.J. 
low status, individuals suffer, and conferring benefits or burdens on prominent individuals within a group is one way to raise or lower the group's status. Ultimately, a large part of the point of raising the status of disadvantaged groups is to secure better lives for individuals. Disparate impact law, on any conception, will affect both individuals and groups, just as antidiscrimination law does more broadly.

Nonetheless, different approaches to disparate impact law have different emphases. In the prevailing equality jurisprudence, the prohibition of deliberate discrimination sounds chiefly in individualism. The judicially enforced conception of equal protection, which is limited to a concern with intentional discrimination, ${ }^{231}$ is repeatedly described as pertaining to individuals rather than groups. ${ }^{232}$ Moreover, because intentional discrimination is an offense to any individual's dignity regardless of that individual's place in the social order, people of dominant groups are entitled to the same protections against intentional discrimination as people of disadvantaged groups. ${ }^{233}$ These strands are woven together in an approach that sees the right to be free from discrimination as every individual's right to be judged without reference to characteristics - paradigmatically race — that are considered to be morally arbitrary. ${ }^{234}$

I669, I67I-72, I683-87 (I990) (describing how legal categories that seem to be defined in opposition to each other often actually borrow significant elements from each other).

231 See Pers. Adm'r v. Feeney, 442 U.S. 256, 274 (1979) (holding that "purposeful discrimination 'is the condition that offends the Constitution'" (quoting Swann v. Charlotte-Mecklenburg Board of Education, 402 U.S. I, I6 (I97 I))); Washington v. Davis, 426 U.S. 229,240 (I976) (citing "the basic equal protection principle that the invidious quality of a law claimed to be racially discriminatory must ultimately be traced to a racially discriminatory purpose").

232 See, e.g., Grutter, 123 S. Ct. at 2337 (stating that "the Fourteenth Amendment protects persons, not groups" (quoting Adarand Constructors, Inc. v. Pena, 5 I 5 U.S. 200, 27 (I 995 )) (internal quotation marks omitted)); Miller v. Johnson, 5 I5 U.S. 900, 9 I I (I995) ("At the heart of the Constitution's guarantee of equal protection lies the simple command that the Government must treat citizens as individuals ..." (quoting Metro Broadcasting, Inc. v. FCC, 497 U.S. 547, 602 (I990) (O'Connor, J., dissenting) (quoting Arizona Governing Committee for Tax Deferred Annuity $\mathcal{E}$ Deferred Compensation Plans v. Norris, 463 U.S. I073, 1083 (1983)) (internal quotation mark omitted)).

233 See City of Richmond v. J.A. Croson Co., 488 U.S. 469, 493 (r 989) (plurality opinion) (emphasizing that those denied an "opportunity to compete for a fixed percentage of public contracts based solely upon their race" have as much of a "personal right[] to be treated with equal dignity and respect" as the intended beneficiaries of the racial set-aside scheme (internal quotation marks omitted)); Adarand, 5 I5 U.S. at 222 (reiterating Croson's point that "the standard of review under the Equal Protection Clause is not dependent on the race of those burdened or benefited by a particular classification" (citation omitted)).

234 Cf. Reva B. Siegel, Discrimination in the Eyes of the Law: How "Color-Blindness" Discourse Disrupts and Rationalizes Social Stratification, 88 CAL. L. REV. 77, 92-93, 98-99, 103-05 (2000) (describing law's formal race discourse according to which the essence of individualism is the elimination of race, a social and moral irrelevance, from the set of criteria on which individuals may be judged, and critiquing that discourse as being at odds with other aspects of equal protection discourse in which existing distributions of wealth and power are assumed, rightly or 
Upon careful consideration, this pairing of the prohibition against intentional discrimination with individualism is too hasty. Discrimination is always partly about groups, inasmuch as the criterion of discrimination is a group attribute. Systematic deliberate discrimination creates hierarchy precisely because it affects the status of groups as well as of individuals. Indeed, in a world without racial hierarchy, we would probably not prohibit deliberate racial discrimination, just as we do not now prohibit discrimination on the basis of left-handedness or being born on odd-numbered days of the month. But modern doctrine has marginalized these nuances and instead promoted a view on which we prohibit intentional discrimination as a matter of defending individual dignity, without regard to questions of hierarchy and social structure. ${ }^{235}$

Integration and hierarchy are obviously about groups. They are also about individuals within those groups, and a concern with racial hierarchy need not (and should not) invest groups with moral significance independent from that of the individuals who compose them. ${ }^{236}$ A proper concern with breaking down racial hierarchy aims ultimately to free affected individuals from the burdens that attend membership in a disadvantaged racial group, not to equalize the status of racial group constructs for their own sake. But racial hierarchy is a relationship among groups, and laws concerned with breaking down hierarchy may therefore operate at the level of groups. The conception of disparate impact law as motivated by the desire to end racial hierarchy in employment is in this way more group-oriented than the conception of disparate impact law as an evidentiary dragnet. ${ }^{237}$

Equal protection is and should be skeptical of group treatment. The reasons for that skepticism, however, could in principle be rooted either in individualism or in concerns about hierarchy. The fact that disparate impact doctrine is more reconcilable with equal protection on an evidentiary dragnet theory than on an anti-hierarchy theory is rooted in the modern Court's choice to privilege individualism as a core equal protection value. This Part analyzes equal protection's relationship to group treatment and assesses the tension between the in-

wrongly, to be attributable to socially relevant differences between members of different racial groups).

235 See supra section II.B.I, pp. 520-23.

236 See Brest, supra note $\mathrm{I}$, at 50 (arguing that the antidiscrimination principle "attributes no moral significance to membership in racial groups," but instead is a theory of just treatment for individuals).

237 The conception of disparate impact doctrine as concerned with subconscious discrimination mediates the tension between individual and group orientations, just as it shares elements with both the idea of discovering hidden intentional discrimination and the idea of redressing structural hierarchies. 
dividualism that currently characterizes equal protection and disparate impact doctrine's orientation toward groups.

Group treatment, like legislative motive, is related to but analytically distinct from the issue of classification. In most instances in which classifications are used, they are used for some form of group treatment. People who are classified as members of different racial groups are then treated differently, or at least separately, from one another. It is possible, however, to have express racial classifications without group treatment. That would be the case in any context in which people were identified as belonging to different racial categories but no differential treatment resulted from the categorization. ${ }^{238}$ One could argue, of course, that the fact of classification itself is a form of differential treatment, because being identified as African-American is different from being identified as Asian-American or Hispanic even if no further differential treatment were based upon that distinction. On that view, classification alone is sufficient to establish group treatment. "Group treatment" as I use the term, however, refers to differential treatment beyond the fact of classification itself. ${ }^{2.39}$

Group treatment commonly violates equal protection because the treatment afforded to members of different groups is substantively different, with some groups treated more favorably than others. But group treatment can also violate equal protection when the treatment afforded to people in different racial groups is substantively the same. The canonical example, of course, is that a state may not maintain separate but equal schools for students of different races. ${ }^{240}$

\section{A. Hierarchy and Individualism}

Two different frameworks might explain why separate but equal group treatment violates equal protection. One is about hierarchy, and the other is about individualism. A court operating within the framework of hierarchy would say that the reason the government cannot operate separate school systems for children of different races is that

238 Examples, or approximate examples, might include the use of racial data in epidemiological studies or in census-taking. The reason that these examples may be only approximate, however, is that epidemiological and census data are ultimately used in the process of allocating many kinds of goods, and information about the racial composition of the population in a given area may affect those allocations. Thus, even though classification and group treatment are analytically distinct, it may be that in practice classification is rarely undertaken except when the information is likely to have some distributive consequence.

239 It is also possible to have group treatment without a system of express classifications. The classic example is Yick Wo v. Hopkins, I 18 U.S. 356 (I886), in which a state actor treated Chinese applicants for laundry permits differently from white applicants but did so without any formal policy of classification. Id. at 374 .

240 See Brown v. Bd. of Educ., 347 U.S. 483, 495 (1954) (holding that segregation in public educational facilities violated equal protection guarantees). 
such a practice, considered against the background of American history and social structure, would reflect and reinforce the presumed dominance of whites and the presumed inferiority of others - notably, though not exclusively, blacks. ${ }^{241}$ On this view, there is really no such thing as "separate but equal," because all group treatment in fact operates as preferential or hierarchical treatment. ${ }^{242}$

241 The pedigree of this position includes Justice Harlan's dissent in Plessy v. Ferguson, 163 U.S. 537 (1896). Unlike the Plessy majority, which was satisfied with formally equal treatment, Justice Harlan recognized that enforced separation of black and white passengers on railroad cars was a means of enforcing a social hierarchy. See id. at 557 (Harlan, J., dissenting) ("Every one knows that the statute in question had its origin in the purpose, not so much to exclude white persons from railroad cars occupied by blacks, as to exclude colored people from coaches occupied by or assigned to white persons."); $i d$. at 559 (referring to the Court's decision to uphold the segregation statute as a violation of the principle that "[t]here is no caste here").

242 Claims that group treatment inherently operates as preferential treatment come in at least two varieties. One of these contests the premise that separate treatment can be substantively the same. The other admits that separate treatment can be substantively the same but maintains that the fact of racial differentiation nonetheless introduces an element of hierarchy and preference. The example of segregated schools lends itself to the first kind of argument. In the hypothetical case in which racially segregated schools were equally well-funded and equally well-run, this argument would say, black or Latino schools still might not be able, on average, to prepare students for success in the adult world as well as white or integrated schools could. Given the distribution of power in American workplaces, perhaps graduating from school without having interacted with white people would be more likely to limit one's professional prospects than would graduating from school without having interacted with black people. It is also the case, however, that some black students might find all-black educational environments better than integrated environments. See Missouri v. Jenkins, 515 U.S. 70, I 2 I-22 (1995) (Thomas, J., concurring) (arguing that "there is no reason to think that black students cannot learn as well when surrounded by members of their own race as when they are in an integrated environment" and characterizing the idea that being educated in nonintegrated environments is harmful to blacks as "based upon a theory of black inferiority"). Or perhaps employers who acted upon generalized stereotypes about prospective employees would react more favorably to a job applicant from the white or integrated school than to an applicant from the black school, even if each applicant had achieved the same degree of success within his own school. If these or any similar arguments were empirically valid, then separate treatment would be unequal for the simple reason that the fact of separate treatment would bring about substantive differences in the experiences of the two groups.

It is also possible, though perhaps more difficult, to make the second kind of argument namely, that all group treatment operates as hierarchical treatment - even without contesting the premise that some separate treatment can be substantively the same. Imagine, for example, a world in which whites and blacks have their income tax returns processed at separate facilities but experience no difference in the taxpaying process aside from placing different address labels on their payment envelopes. There is no reason why the separate tax-processing facilities could not be equally efficient. Under those conditions, which facility processed a given taxpayer's return should have no impact on his or her future life circumstances: it would be as irrelevant as the fact that my taxes are processed at the IRS facility in Massachusetts rather than the one in New York. Nonetheless, the fact of racial differentiation might introduce an element of hierarchy even in this situation of substantively identical treatment. Given the historical and existing racial hierarchies in American society, the argument would run, any group racial treatment helps perpetuate a system of racial categories that operates to the disadvantage of particular groups. In this more subtle way, one might argue, separate but equal treatment is hierarchical even if it is substantively the same for all groups. But see Michael C. Dorf, Equal Protection Incorporation, 88 VA. L. REV. 95 I, 960 (2002) (noting that it is "possible to conceive of a hypothetical society in which segregation connotes no subordinate status for one group or the other"). 
The explanation from individualism, in contrast, need not contest the substantive parity of the separate treatment afforded to members of different groups. According to this perspective, treating individuals as members of racial groups is a problem even if doing so does not establish or perpetuate a hierarchy. Irrespective of concerns about the relative status of a racial group as a whole, group treatment can limit particular individuals' choices on the basis of race. Consider a law designating one school exclusively for Native Americans and another exclusively for Latinos. Even if there is nothing objectively superior about the Native American school, perhaps some Latinos will want to attend it as a matter of subjective preference, and denying them that possibility may impose an unfair limitation on them. ${ }^{243}$

For someone who is concerned about the perpetuation of hierarchies, a decision to approach equal protection through the lens of individualism is troubling for several reasons. First, that choice creates constitutional impediments to many government attempts to improve the status of disadvantaged racial groups. Racially classificatory affirmative action is an obvious example. Second, individualism tends to be a present-oriented worldview. Its vision of people as independent, self-contained entities severs them not just from group affiliations but also from continuity with events that occurred before they were born or reached adulthood. Individualism therefore deflects attention from the role that historical discrimination played in creating conditions under which the present application of formally neutral rules nonetheless perpetuates the subordination of disadvantaged groups. Third, the rhetoric of individualism obscures the persistence of segregation and hierarchy as empirical social conditions. When authoritative speakers such as courts articulate a vision of a world in which people's life chances are and should be a function of character and talent alone, ${ }^{244}$ it is easy to underestimate the degree to which an Ameri-

\footnotetext{
243 There is also a more abstract reason why nonpreferential group treatment could be a problem from the standpoint of individualism. Such group treatment can entail "expressive harm" because it evinces or communicates the idea that people should be seen as members of racial groups rather than as individuals. (Whether expressive harm is better understood in terms of evincing ideas or communicating them is discussed below. See infra Part IV.) In a society that aspires to end race-based divisions, that idea is disfavored even if it comes with no hierarchical component. See, e.g., City of Richmond v. J.A. Croson Co., 488 U.S. 469, 495 (1989) (plurality opinion) ("The dissent's watered-down version of equal protection review effectively assures that race will always be relevant in American life, and that the 'ultimate goal' of 'eliminat[ing] entirely from governmental decisionmaking such irrelevant factors as a human being's race' will never be achieved." (alteration in original) (quoting Wygant v. Jackson Board of Education, 476 U.S. 267, 320 (I986) (plurality opinion))). Indeed, the idea that people should be treated as members of racial groups rather than as individuals is disfavored even if it is not accompanied by any concrete instance of differential treatment on the basis of race.

244 See, e.g., Grutter v. Bollinger, I 23 S. Ct. 2325, 2350 (2003) (Thomas, J., concurring in part and dissenting in part) ("If the apples will not remain on the tree of their own strength, if they are
} 
can child's schooling, social networks, and informal opportunities may be affected by the boundaries of the racially shaped community in which he or she lives. As a result, individualism can reinforce the idea that affirmative efforts to improve the status of disadvantaged racial groups are not only illegitimate but also unnecessary. ${ }^{245}$ From a progressive policy perspective, these features of the individualist ideal are serious vices.

But from the perspective of the Rehnquist Court, which has chosen individualism rather than hierarchy as the paradigm for understanding equal protection's aversion to group treatment, ${ }^{246}$ the foregoing features of individualism are among its most important virtues. These features permit the Court to maintain a status quo orientation that reaffirms the essential justice of the legal system even while historically victimized groups continue to experience systematic disadvantage. Consider the alternative: adopting the framework of hierarchy would require the Court to acknowledge that race continues to structure American society in unhealthy ways. In most areas, the Court parries that awareness, preferring to deny connections between race and contemporary social structure even when those connections are manifestly present. $^{247}$ One example is the Croson Court's refusal to infer a his-

worm-eaten at the core, if they are early ripe and disposed to fall, let them fall! . . And if the negro cannot stand on his own legs, let him fall also." (omission in original) (quoting Frederick Douglass, What the Black Man Wants: An Address Delivered in Boston, Massachusetts, on 26 January $\mathrm{I} 865$, reprinted in 4 THE FREDERICK DOUGlass PAPERS 59, 68 (J. Blassingame \& J. McKivigan eds., 199 (1))).

245 See, e.g., id. ("Like Douglass, I believe blacks can achieve in every avenue of American life without the meddling of university administrators.").

246 See, e.g., Gratz v. Bollinger, I 23 S. Ct. 24 I I , 2428-3 I (2003) (striking down an undergraduate affirmative action program because it failed to treat applicants in a sufficiently individualized manner); Grutter, I23 S. Ct. at 2343-47 (upholding a law school affirmative action program found to treat applicants as unique individuals rather than as members of racial groups); id. at 2337 (stating that the Fourteenth Amendment "protect[s] persons, not groups" (alteration in original) (quoting Adarand Constructors, Inc. v. Pena, 515 U.S. 200, 227 (I995)) (internal quotation marks omitted)); Miller v. Johnson, 5 I5 U.S. 900, 9I I (I995) ("The idea is a simple one: 'At the heart of the Constitution's guarantee of equal protection lies the simple command that the Government must treat citizens "as individuals ..."”" (quoting Metro Broadcasting, Inc. v. FCC, 497 U.S. 547, 602 (1990) (O'Connor, J., dissenting) (quoting Arizona Governing Committee for Tax Deferred Annuity $\mathcal{E}$ Deferred Compensation Plans $v$. Norris, 463 U.S. 1073 , 1083 (1983)))); Croson, 488 U.S. at 493 (" $[R]$ ights created by the first section of the Fourteenth Amendment are, by its terms, guaranteed to the individual. The rights established are personal rights." (quoting Shelley v. Kraemer, 334 U.S. 1, 22 (1948)) (internal quotation marks omitted)). For an uncompromising version of the claim that the Rehnquist Court's individualist view has almost always been the exclusive version of equality in Supreme Court doctrine, see Charles Fried, The Supreme Court, ro8g TermComment: Metro Broadcasting, Inc. v. FCC: Two Concepts of Equality, 104 HARV. L. REV. 107 (1990). Fried writes: "Except for the shameful and discredited 'separate but equal' doctrine of Plessy v. Ferguson, the Supreme Court has always adhered to a liberal, individualistic view of the equal protection guarantee." Id. at I 07 (footnote omitted).

247 For a survey of examples other than those presented here, see Michael Selmi, Proving Intentional Discrimination: The Reality of Supreme Court Rhetoric, 86 GEO. L.J. 279, 283-84 (I997). 
tory of racial discrimination in the contracting industry in Richmond, a city where Jim Crow had officially reigned barely twenty years before and where, despite the fact that the population was roughly fifty percent black, less than one percent of prime municipal construction was handled by minority-owned businesses. ${ }^{248}$ Another example is the way cases like Miller $v$. Johnson ${ }^{249}$ construe equal protection to suppress or reject the idea of a connection between race and political preference among African Americans, ${ }^{250}$ even though being black is empirically a powerful predictor of voting behavior. ${ }^{251}$ By prohibiting states from recognizing the powerful empirical link between race and voting, the Court paints a picture of a polity in which race is unconnected to the factors that everyone agrees can legitimately shape political preferences, such as ideology and economic interests. In contemporary America, these factors are not severed from race as an empirical matter, and the reasons why they are not have a lot to do with ongoing de facto segregation and the different community interests that this segregation creates. By taking the empirical link between race and voting off the table in the name of the ideal that individuals should form their views independently of their racial affiliations, the Court obscures the degree to which race continues to shape the lives and interests of many black Americans. The individualist impulse in equal protection thus offers an escape from confronting the depressing degree to which race influences the lives of members of historically subordinated groups. It invites us instead to bathe in a sunnier worldview informed by ideals of universal human potential. ${ }^{252}$

See also id. at 284 (arguing that since the 1970 , "the Court has only seen discrimination ... in the most overt or obvious situation - situations that could not be explained on any basis other than race").

248 Croson, 488 U.S. at $479-80,501-03$. It should also be remembered, however, that the pattern of denying awareness of the continuing effects of hierarchy and discrimination is not entirely unbroken, even within the Court's more conservative wing. See, e.g., Virginia v. Black, I 23 S. Ct. $1536,1563(2003)$ (Thomas, J., dissenting) (surveying the history of cross-burning to argue that the practice necessarily involves intent to terrorize and intimidate and arguing that "a page of history is worth a volume of logic" (quoting Texas v. Johnson, 49 I U.S. 397, 42 I (I989) (Rehnquist, C.J., dissenting) (quoting New York Trust Co. v. Eisner, 256 U.S. 345, 349 (I92 I))) (internal quotation marks omitted)).

2495 I 5 U.S. 900 (1995).

$250 \mathrm{See} i d$. at 914,920 (finding that when a state creates a redistricting plan based on the assumption that race predicts voting patterns, it engages in a form of racial stereotyping that is subject to strict scrutiny); see also Holder v. Hall, 5 I 2 U.S. 874, 903-07 (I 994) (Thomas, J., concurring in the judgment) (arguing that redistricting plans should not take account of links between race and political preference).

251 See Lublin \& Voss, supra note 217 , at 769-70; Richard H. Pildes, The Politics of Race, 108 HARV. L. REV. 1359, 1378-79 n.84 (I995) (book review) (noting that in the South between I990 and I994, the Democratic Party garnered only thirty-five percent of the white vote but ninety-one percent of the black vote).

252 See, e.g., Croson, 488 U.S. at 505-06 (invoking "[ $t$ ]he dream of a Nation of equal citizens in a society where race is irrelevant to personal opportunity and achievement"). 
This is not to say that the Rehnquist Court's vision of equal protection refuses to take any notice of racial group hierarchies whatsoever. Notably, the interest in diversity that Grutter deemed compelling enough to justify affirmative action in law school admissions is in part about mitigating the effects that existing racial hierarchies have on the composition of national leadership cadres. To maintain the democratic legitimacy of our political institutions, the Court wrote, it is necessary for people of all racial groups to hold legislative and judicial offices, lest the public come to believe that such positions are only open to a privileged subset of the population. ${ }^{253}$ Successful aspirants to seats in Congress and on the federal bench are disproportionately graduates of elite law schools, so the law schools need to be able to enroll students from disadvantaged racial groups. ${ }^{254}$ This version of the compelling interest in diversity traffics directly in concerns about the status of groups. It sees affirmative action as necessary not only because students reap educational benefits by attending school with people different from themselves but also because the alternative is the visible perpetuation of racial hierarchy. 255

It is not clear, however, that the compelling interest in avoiding the appearance of hierarchy in the nation's leadership is founded on the values of equal protection. It may instead be a concern founded on a rival value, like the political need for "legitimacy,"256 that in this case trumps equal protection's individualist demands. ${ }^{257}$ Both the rhetoric

253 See Grutter v. Bollinger, 123 S. Ct. 2325, $234^{\text {I }}$ (2003) ("In order to cultivate a set of leaders with legitimacy in the eyes of the citizenry, it is necessary that the path to leadership be visibly open to talented and qualified individuals of every race and ethnicity.").

254 Id. ("Moreover, universities, and in particular, law schools, represent the training ground for a large number of our Nation's leaders. . . Individuals with law degrees occupy roughly half the state governorships, more than half the seats in the United States Senate, and more than a third of the seats in the United States House of Representatives.... The pattern is even more striking when it comes to highly selective law schools. A handful of these schools accounts for 25 of the Ioo United States Senators, 74 United States Courts of Appeals judges, and nearly 200 of the more than 600 United States District Court judges.").

255 See Robert C. Post, The Supreme Court, 2002 Term-Foreword: Fashioning the Legal Constitution: Culture, Courts, and Law, I 7 HARV. L. REV. 4, 59-64 (2003) (comparing this version of the compelling interest in diversity with the version that focuses on diversity's educational benefits as articulated by Justice Powell in Bakke).

256 Grutter, 123 S. Ct. at $234 \mathrm{I}$.

257 When a court analyzes a constitutional challenge to a state action and the compelling interest that the state action is alleged to serve, the compelling interest need not be rooted in the same constitutional clause, or the same set of constitutional values, that is the basis for the challenge. By way of illustration, recall Korematsu $v$. United States, 323 U.S. 2 I4 (1944). The petitioner in that case challenged the military exclusion orders on the grounds that they violated the guarantee of due process of law, and the Court held that a compelling interest in national security was sufficient to sustain the orders. Id. at 219-20. But the national security interest was not itself a matter of due process: it was a different interest that trumped the due process concern in the case at issue. Similarly, the compelling interest that trumped the First Amendment claim in Burson $v$. 
and the doctrine of Grutter - and of Gratz - are committed to individualism as the dominant understanding of equal protection. Repeating a simple slogan from Adarand, the Grutter majority insisted that the Fourteenth Amendment "protect[s] persons, not groups."258 To be sure, that slogan obscures the complex interplay of individualist and group-oriented ideas that Grutter sanctioned, but it clearly communicates the Court's preference for individualism as the paradigm for equal protection.

Grutter and Gratz permit only affirmative action that can be practiced without compromising the commitment that applicants will be treated as unique individuals. ${ }^{259}$ Exactly what it means to treat applicants as individuals is, and will surely continue to be, a contested question. After Grutter, individual treatment can include some consideration of race, though it is difficult to say how much and what kind. ${ }^{260}$ To whatever degree individualism tolerates race-conscious de-

Freeman, 504 U.S. I9I (I992), was not a First Amendment interest; it was the interest in preventing fraud and voter intimidation in elections. See id. at 206.

By the same token, the compelling interest that permits a state to practice affirmative action in the face of an equal protection challenge need not be an interest based on equal protection. The diversity interest understood as an interest in improving the education of all students is presented as an interest rooted in the values of "academic freedom" rather than in the values of equal protection. See Grutter, 123 S. Ct. at 2336; Regents of Univ. of Cal. v. Bakke, 438 U.S. 265,312 ( 1978 ) (opinion of Powell, J.) ("Academic freedom, though not a specifically enumerated constitutional right, long has been viewed as a special concern of the First Amendment."). Because the version of the diversity interest that speaks explicitly of the need for visibly diverse national leadership is in substance a concern about racial group hierarchy, it may be an interest that sounds in equal protection, especially if one is inclined to see hierarchy as the core equal protection concern. But it is also possible to argue that equal protection is concerned with individualism, not with hierarchy, and that the compelling interest in a visibly diverse national leadership is not an interest based on equal protection at all. It is, on that view, a non-equal-protection interest that can, in certain cases, trump the values of equal protection, just as a compelling interest in academic freedom can sometimes trump equal protection, or a compelling interest in national security can sometimes trump due process.

258 Grutter, 123 S. Ct. at 2337 (quoting Adarand Constructors, Inc. v. Pena, 5 I5 U.S. 200,227 (I995)) (internal quotation marks omitted).

259 See Gratz v. Bollinger, I23 S. Ct. 24 I I, 2427-28 (2003) (rejecting the college's argument that its method of evaluating applicants provided the "individualized consideration" that could in principle render a race-conscious policy constitutional and finding that " $t]$ he current ... policy does not provide such individualized consideration"); Grutter, $123 \mathrm{~S}$. Ct. at 2342-43 (emphasizing that "truly individualized consideration demands that race be used in a flexible, nonmechanical way," that "a university's admissions program must remain flexible enough to ensure that each applicant is evaluated as an individual and not in a way that makes an applicant's race or ethnicity the defining feature of his or her application," and that "[t]he importance of this individualized consideration in the context of a race-conscious admissions program is paramount," and then finding that the law school's "highly individualized" method of evaluating applicants was acceptable).

260 This is a particularly noteworthy development inasmuch as one understanding of "individualism" prior to Grutter was simply the exclusion of racial considerations. See Siegel, supra note 234, at 92-93. According to Siegel, “[t]he essence of 'individualism' [is] to categorize persons and discriminate among them on the basis of . . 'socially relevant characteristics."' Id. at 93. This 
cisionmaking, it may incorporate within itself some of the concerns with racial hierarchy that a strictly colorblind regime would reject. But even so, it is individualism rather than hierarchy that operates as the dominant meaning of equal protection. It is an individualism that is not entirely blind to race, but it insists on being individualism nonetheless.

\section{B. Disparate Impact Doctrine in an Individualist Regime}

If the Court viewed equal protection through the lens of hierarchy, disparate impact doctrine would have little to fear from equal protection. To whatever extent disparate impact law involves the use of racial groups as units of analysis, it does so in a way that is friendly to the cause of eroding hierarchy in the workplace. A vision of equal protection directed at ending racial hierarchy would thus operate in tandem with disparate impact doctrine rather than at cross-purposes with it. Given, however, that the prevailing paradigm for equal protection analysis is now individualism, there are reasons to think that a disparate impact doctrine concerned with group-oriented issues like segregation and hierarchy might collide with individualism's suspicion of group treatment. After all, Title VII does measure liability by examining how a given employment practice affects groups. It therefore encourages employers to think of their workforces at least partly in racial terms, prompting them to monitor the racial composition of those workforces and the applicant pools from which they are selected. ${ }^{261}$

model "entitles persons to protection from classification on the basis of formal-race only." Id. at 92.

261 As a practical matter, a desire to avoid litigation may prompt employers to use race as a factor in hiring decisions. It is not clear, however, whether litigation considerations would lead employers to hire more or fewer members of racial minority groups. According to one conventional account, litigation considerations would make employers more inclined to practice affirmative action on the reasoning that although numerical data on bottom-line workplace composition is not enough by itself to defeat a claim under Title VII, in practical terms an employer who hires nonwhite workers in proportions roughly corresponding to their representation in the relevant labor market may see fewer lawsuits. See Belton, supra note 155, at 231-33 (arguing that employers have adopted affirmative action plans to reduce racial and sexual disparities in their workforces and thereby make it more difficult for plaintiffs to use statistical evidence to support disparate impact claims); Rutherglen, supra note 109 , at 133 (arguing that "the theory of disparate impact has increased the pressure on employers to find other means of integrating the workplace, mainly through various forms of affirmative action"). This account is not necessarily correct. Because far more Title VII suits concern termination than failure to hire, employers have an incentive to avoid hiring nonwhites in the first place if subsequent layoff or firing practices could fall disproportionately on those groups and thus give rise to disparate impact liability on the back end. See Ian Ayres \& Peter Siegelman, The Q-Word as Red Herring: Why Disparate Impact Liability Does Not Induce Hiring Quotas, 74 TEX. L. REv. I487, I489 (I996) (arguing that "disparate impact firing liability almost certainly blunts the positive incentives to hire minorities that Title VII was originally supposed to create"); Paul Oyer \& Scott Schaefer, Sorting, Quotas, and the Civil Rights Act of 19gI: Who Hires When It's Hard To Fire?, 45 J.L. \& ECON. 4I, 67 (2002) (citing evidence suggesting that in the mid-r $990 \mathrm{~s}$, a "quota effect" tending to increase hiring of women and minori- 
Nonetheless, even taking the view that disparate impact doctrine is designed to counter hierarchy, it would be a mistake to view the doctrine as woodenly group-oriented, because disparate impact doctrine is in fact a complex combination of individualist and anti-hierarchical elements. ${ }^{262}$ Consider, for example, the issue of the "bottom-line defense." If one aspect of a hiring process has a disparate impact on black job applicants, but other parts of the overall hiring process work to the disproportionate benefit of blacks (whether through affirmative action or otherwise) such that a proportional number of blacks are hired in the end, an employer might try to defend against a disparate impact claim on the ground that its hiring process, considered as a whole, does not disadvantage blacks. In Connecticut $v$. Teal, the Supreme Court disallowed this bottom-line defense. ${ }^{263}$ To permit such a defense, the Court explained, would be to make disparate impact analysis wholly about group numbers rather than about individual applicants. ${ }^{264} \mathrm{~A}$ policy that ultimately results in a proportional number of blacks being hired, the Court reasoned, does not help the particular black applicants who are screened out by the parts of the policy that have a disparate racial impact. ${ }^{265}$ The injury these applicants suffer when they are eliminated from the competition for jobs is not redressed by affirmative action that benefits other black applicants. ${ }^{266}$ By conceptualizing the relevant legal injury as one that is suffered by individual black applicants and that cannot be redressed by satisfactory treatment for the group as a whole, the Teal Court lodged a significant element of individualism in the framework of disparate impact law.

I. Applying the Rules: Race Neutrality. - Nothing in disparate impact doctrine calls for individual employees or applicants to be treated differently from one another on racial grounds at the moment an employment decision is made. ${ }^{267}$ This is a subtle fact about the

ties was outweighed by a "sorting effect" tending to decrease hiring of women and minorities by firms susceptible to litigation).

262 For a treatment of how legal doctrine in the analogous area of voting rights can be viewed as neither individualist nor group-oriented, but something in between, see Gerken, supra note $\mathrm{I} 6$, at $1666-67$. Gerken discusses a category of "aggregate rights" in which individual rights depend on the treatment of groups.

263457 U.S. 440,456 ( 1982 ).

264 See id. at $453-54$.

265 Id. at 455 ("Irrespective of the form taken by the discriminatory practice, an employer's treatment of other members of the plaintiffs' group can be 'of little comfort to the victims of ... discrimination." (quoting International Brotherhood of Teamsters $v$. United States, 43 I U.S. $324,342($ I 977$)$ ).

266 Id. ("Title VII does not permit the victim of a facially discriminatory policy to be told that he has not been wronged because other persons of his or her race or sex were hired.").

267 The qualification "at the moment an employment decision is made" is necessary because the doctrine does cause people to be treated differently at other times, including during litigation. See 
doctrine and perhaps a counterintuitive one, because many aspects of disparate impact law are group-oriented. Disparate impact doctrine's operation requires people to be classified into racial groups, and liability hinges on a comparison of the statuses of those groups. Nonetheless, disparate impact doctrine differs from Gratz- or Adarand-style affirmative action in that it does not call for selection processes in which applicants are scored differently based on race. It is more like the alternative action device of lowering a cutoff score, as practiced in cases like Byers $v$. City of Albuquerque ${ }^{268}$ : at the moment of decision, everyone is subject to the same criteria.

To see how this aspect of disparate impact law works, consider a hypothetical fact pattern involving a hiring process based on written tests. The employer in this example requires all applicants to take two written tests called Test A and Test B, each of which is scored from I to I00. The employer hires applicants with a combined score of 150 or better. It turns out that Test $\mathrm{A}$ has a disparately adverse impact on black applicants as compared with white applicants, and the employer cannot demonstrate that Test $\mathrm{A}$ is required by business necessity, so the employer eliminates Test A. The employer now uses only Test B, hiring applicants with a score of 75 or more on that test.

Consider now how each of two applicants - let's call them Ms. White and Ms. Black - fares under this employer's criteria. Assume that Ms. White, who is white, scores 90 on Test A and 70 on Test B. She would have been hired under the employer's original criteria, because her combined score of I60 exceeds the cutoff score of 150 , but she will not be hired under the revised criteria, because her score of 70 falls short of the cutoff point of 75. Next, assume that Ms. Black, who is black, scores 60 on Test A and 80 on Test B. She would not have been hired under the original criteria, because her combined score was only I 40 . But her score of 80 on Test $B$ will get her hired under the revised criteria.

On these facts, the operation of disparate impact doctrine reallocates one position from a white applicant to a black applicant. ${ }^{269}$ Accordingly, Ms. White can truthfully claim that she has been denied a job that she would have gotten but for the operation of Title VII. Ms. White cannot claim, however, that the employer's revised hiring proc-

\footnotetext{
supra pp. 545-47; see also supra pp. 542-43 \& nn.202-03 (discussing Byers v. City of Albuquerque, I50 F.3d I27 I (Ioth Cir. 1998)).

268 I 50 F.3 I 27 I (Ioth Cir. 1998).

269 It is obvious that this particular reallocation is an artifact of the numbers I have arbitrarily chosen for the example, but it is necessarily the case that the change in criteria will reallocate some number of positions from whites to blacks. That Test $\mathrm{A}$ has a disparately adverse impact on blacks means, other things being equal, that eliminating Test $\mathrm{A}$ will raise the proportion of successful applicants who are black.
} 
ess treated her differently on the basis of race from the way it treated Ms. Black. ${ }^{270}$ Ms. White was not given a different test from Ms. Black, nor was her test scored differently. The revised hiring criteria, just like the original ones, applied in exactly the same way to both candidates. In this important respect, disparate impact law avoids the differential group treatment that characterizes the kind of affirmative action practiced in Adarand and Gratz. The absence of differential group treatment at the moment of the employment decision puts disparate impact law less at odds with equal protection doctrine than affirmative action is.

2. Changing the Rules: Racial Difference. - There are, however, limits to the characterization of disparate impact doctrine as a framework that affords the same treatment to people of different races. If we ask only about the set of rules that the employer uses to decide whom to hire, it is true that the same rules apply to everyone regardless of race. But if we ask also about the set of rules that determines who can successfully challenge a given employment practice, people from different groups are treated differently.

Think again of Ms. White and Ms. Black. This time, assume that both are applicants in a job process that involves a facially neutral written test with a passing score of 75 . Assume further that both do equally poorly on the test, scoring 60 points and therefore not qualifying for employment. Both Ms. Black and Ms. White have an interest in eliminating the use of the test: neither will be employed if the test is used, and both might have a chance at employment if the test is eliminated. ${ }^{271}$ Nonetheless, if the test has a disparate impact by race, and assuming (as is most frequently the case) that it is Ms. Black and not Ms. White who is a member of the adversely affected racial group, only Ms. Black can bring a Title VII disparate impact claim. ${ }^{272}$ Con-

270 Someone in Ms. White's position thus faces a situation exactly inverse to that faced by most white plaintiffs in traditional affirmative action cases. Many such affirmative action plaintiffs could reasonably claim that they would have been hired had they been of the favored group, but most could not plausibly claim that they would have been hired if there had been no affirmative action plan. See Goodwin Liu, The Causation Fallacy: Bakke and the Basic Arithmetic of Selective Admissions, I00 MICH. L. REV. I045, 1094-95 (2002) (noting, in the context of selective university admissions, that statistics indicate that the vast majority of rejected white candidates have no plausible claim that they would have been admitted under a race-neutral plan). In contrast, Ms. White would have been hired had there been no disparate impact law, but given the existence of such a law, her race is irrelevant to the decision not to hire her. She would not have been hired even if she had been black.

271 Cf. GUINIER \& TORRES, supra note I I I, at 131-35 (noting similar cross-racial shared interests in the labor context).

272 Ms. Black's standing to bring this claim where Ms. White could not cannot be attributed to a greater individual interest Ms. Black has in eliminating the test. Even assuming that the test has a disparately adverse impact on blacks, it is not necessarily the case that Ms. Black will have a greater statistical chance of employment than Ms. White if the test is eliminated. Whether she will depends on a number of factors, such as the distribution of black and white applicants over- 
ceived in this way, Title VII's disparate impact doctrine does involve an element of differential group treatment by race.

As a practical matter, this element of group treatment is unlikely to influence whether Ms. White is denied employment. If a test that adversely affects Ms. White also has a disparately adverse impact on some nonwhite racial group, there is little reason to think that Ms. White would bring and win a Title VII suit but that persons of the adversely affected racial group would not. If they do, Ms. White will share in the relief. That Ms. White and Ms. Black face different rules for challenging the rules is thus significant less for its practical impact and more for the reminder it furnishes that racial classifications and group treatment are analytically a part of the disparate impact apparatus.

\section{EXPRESSIVE HARM}

To say that an aspect of the law is mostly symbolic, however, is not to say that it can be ignored. The symbolic aspects of a law can be quite important, sometimes even more so than its material effects. ${ }^{273}$ Symbols express attitudes, and attitudes expressed in law can shape the social norms that condition future behavior. A substantial literature addresses these expressive functions of the law. ${ }^{274}$ In the context

all and the kind of decisionmaking process that the employer adopts in place of the invalidated test. Cf. Liu, supra note 270 , at I094-95. Changes that increase the proportion of blacks in a workforce may still benefit a given individual white applicant more than a given individual black applicant. See supra pp. 542-43 (discussing Byers).

Ms. White's lack of standing to bring this claim reinforces the conclusion that the Miner's Canary conception of disparate impact law does not map Title VII. On that conception, Ms. White would be not merely a third-party beneficiary of Ms. Black's claim but also an intended third-party beneficiary and, as such, would probably be entitled to bring the claim in her own right. See supra note i II.

273 See, e.g., Cass R. Sunstein, Incommensurability and Valuation in Law, 92 MICH. L. REV. 779,824 (I994) (arguing that the "real-world consequences" of Supreme Court decisions may often be smaller than the symbolic importance of those decisions). The symbolic aspects of judicial decisions are important because they can and do lead to real-world consequences of their own over time, as discussed below. See sources cited infra note 274 . The contrast here is between the immediate real-world consequences of a judicial decision - damages, injunctions, and the like and the long-term symbolic impact of the decision.

274 See, e.g., Matthew D. Adler, Expressive Theories of Law: A Skeptical Overview, I 48 U. PA. L. REV. ${ }_{13} 6_{3}$ (2000) (addressing the expressive functions of Supreme Court decisionmaking); Elizabeth S. Anderson \& Richard H. Pildes, Expressive Theories of Law: A General Restatement, I 48 U. PA. L. REV. 1503 (2000) (same); Christopher L. Eisgruber, Is the Supreme Court an Educative Institution?, 67 N.Y.U. L. REV. 96 (1992) (same); Dan M. Kahan, Social Influence, Social Meaning, and Deterrence, 83 VA. L. REV. $349,363,382-85$ (1997) (discussing the expressive function of punishment in the context of alternative sanctions for crimes); Dan M. Kahan, What Do Alternative Sanctions Mean?, 63 U. CHI. L. REV. 59I (1996) (same); Richard H. Pildes \& Richard G. Niemi, Expressive Harms, "Bizarre Districts," and Voting Rights: Evaluating Election-District Appearances After Shaw v. Reno, $92 \mathrm{MICH}$. L. REV. 483 (I993) (discussing the expressive function 
of equal protection, one branch of this literature argues that state action can be unconstitutional because of the "expressive harm" that it inflicts. ${ }^{275}$ This idea has solid grounding in case law. Leading decisions from Strauder v. West Virginia ${ }^{276}$ to Brown v. Board of Education $^{277}$ turned at least in part on the anti-egalitarian social meanings of the practices at issue. ${ }^{278}$ More recently, in Adarand, Shaw v. Reno, and Croson, the problem of expressive harm has contributed to the unconstitutionality of race-conscious measures intended to benefit historically disadvantaged groups. ${ }^{279}$

Disparate impact doctrine has not traditionally been thought of as something that might give rise to expressive harms, but that is largely because courts and commentators have not yet begun thinking about disparate impact doctrine as an equal protection problem at all. Once the question is asked, it seems plausible that disparate impact doctrine could be a source of expressive harms. A doctrine that makes the allocation of employment opportunities among racial groups a trigger for

of redistricting and voting rights law); Cass R. Sunstein, On the Expressive Function of Law, I44 U. PA. L. REV. 202 I (1996).

275 See, e.g., ANDREW KOPPELMAN, ANTIDISCRIMINATION LAW AND SOCIAL EQUALITY $57-76$ (I 996 ) (arguing that expressive harms, though important, do not fully account for the harms of racism); Brest, supra note I, at 8-1 I; Kenneth L. Karst, The Supreme Court, 1976 TermForeword: Equal Citizenship Under the Fourteenth Amendment, 9I HARV. L. REV. I, 5-8, 23-24, $48-53(1977)$.

276 100 U.S. 303 (1880).

277347 U.S. 483 (1954).

278 See Brown, 347 U.S. at 494 (explaining that legal segregation was "usually interpreted as denoting the inferiority of the negro group" (quoting a separate, unreported finding of a threejudge court sitting in Brown v. Board of Education, 98 F. Supp. 797 (D. Kan. 195 I))); Strauder, I00 U.S. at 308 (describing the practice of excluding blacks from juries as "practically a brand upon them[,] . . an assertion of their inferiority"). Compare the Court's argument in Plessy v. Ferguson that segregation did not bespeak black inferiority and that if blacks interpreted the law otherwise, that was "solely because the colored race chooses to put that construction upon it." I6 3 U.S. 537,55 I (I 896). This statement can be read to acknowledge that social meaning does matter in equal protection analysis and that, in the view of the Court, Homer Plessy was simply mistaken about the social meaning of Louisiana's separate-coach law. If the law had conveyed an inegalitarian social meaning, it could have presented a constitutional problem. What level of confidence we should have in the judicial competence to identify the social meanings of laws is discussed infra pp. $57 \mathrm{I}-72$.

279 See Adarand Constructors, Inc. v. Pena, 5 I5 U.S. 200, 228-29 (1995) (arguing that racial classifications, even when made with "good intentions," raise equal protection problems because they will be perceived to rest on stigmatizing assumptions about the benefited groups (quoting $i d$. at 245 (Stevens, J., dissenting)) (internal quotation marks omitted)); id. at 24 I (Thomas, J., concurring in part and concurring in the judgment) ("So-called 'benign' discrimination teaches many that because of chronic and apparently immutable handicaps, minorities cannot compete with them without their patronizing indulgence. Inevitably, such programs engender attitudes of superiority or, alternatively, provoke resentment among those who believe that they have been wronged by the government's use of race. These programs stamp minorities with a badge of inferiority ...."); Shaw v. Reno, 509 U.S. 630, 647 (1993) (calling reapportionment "one area in which appearances do matter"); City of Richmond v. J.A. Croson Co., 488 U.S. 469, 493-94 (I989) (plurality opinion) (focusing on the danger of stigmatic harm resulting from racial classifications). 
employer liability does entail a view of individuals as importantly constituted by their membership in racial groups, ${ }^{280}$ and it is not implausible that such a doctrine would engender racial hostility and identity politics. Whether and to what extent these problems actually attend disparate impact doctrine therefore warrants attention.

There is more than one way to think about expressive harm. One approach, which I will call "consequentialist," looks at the communicative impact of a law or legal regime. Government action causes expressive harm in a consequentialist sense if it has actual adverse effects on the normative attitudes of people in society. Another approach, which I will call "revelatory," looks at the background attitude that the government reveals by taking a particular action. A law raises the problem of expressive harm in the revelatory sense not by having some practical communicative impact on society, but by expressing, in the sense of evincing, the worldview of the state actor that made the law.

This Part analyzes disparate impact doctrine first under the consequentialist approach to expressive harm and then under the revelatory approach. It should be noted, however, that reviewing courts might be influenced by both approaches simultaneously. Moreover, it may not be fair to criticize a court's drawing on both approaches to expressive harm as doctrinal inconsistency or even as eclecticism, because the framework of expressive harm is not a distinctive judicial doctrine. It is instead an academic construct that tries to make sense of a set of judicial practices. When judges justify their actions by reference to the social meanings of challenged legislation, academics may analyze those justifications under the rubric of "expressive harm," but judges rarely invoke the term on their own. ${ }^{281}$ Not coincidentally, courts have not developed a comprehensive set of rules for dealing with expressive harm as such. The behavior of judges in hard constitutional cases is often underdetermined even when it purports to be guided by doctrine; when the guide is a court's sense of social meaning, judicial behavior is even more underdetermined.

280 The statement that people are importantly constituted by race could mean either of two things. One is that people's life situations and opportunities are partly determined by racial circumstance. The other is that people should think of race as important to their personal identities. Disparate impact doctrine does entail the former idea, see supra section II.B.2, pp. 523-32, but it need not entail the latter, and it is the latter idea that is more offensive to equal protection. The former idea is also in tension with the Rehnquist Court's vision of individualist equal protection, see supra section III.A, pp. 555-62, but not as strongly so as the latter.

281 There are only two reported federal appellate cases in which the term "expressive harm" appears as anything other than part of a citation of Pildes \& Niemi's Expressive Harms article, supra note 274. Those two cases are Bush v. Vera, 5 I7 U.S. 952, 960, 984 (I g96) (plurality opinion); and Sanchez v. Colorado, 97 F.3d I303, 1328, I329 (10th Cir. 1996). Sanchez takes its use of the term from Bush, and Bush takes the term from Pildes and Niemi. 
This is not to say that the expressive harm approach provides no helpful guideposts at all. The present task, however, is not merely to synthesize an expressive harm doctrine and apply it to disparate impact law. It is also to use the disparate impact question to exfoliate the indeterminacies associated with the idea of expressive harm, just as this Article overall uses that question to identify and map uncertain areas of equal protection more generally.

\section{A. The Consequentialist Approach: Communicative Impact}

A consequentialist theory of expressive harm is concerned with the damage done by the content of messages that laws send. The Brown Court, for example, was concerned with segregation's implication of black inferiority because it believed that such a message, backed by the sanction of the law, "has a detrimental effect upon the colored children."282 Consider also two more recent cases in which Justice O'Connor has articulated a consequentialist approach to expressive harms. For the Shaw Court, Justice O'Connor wrote that race-based districting "reinforces the perception that members of the same racial group ... think alike, share the same political interests, and will prefer the same candidates at the polls" 283 and therefore "may exacerbate the very patterns of racial bloc voting that majority-minority districting is sometimes said to counteract." 284 It also makes "elected officials ... more likely to believe that their primary obligation is to represent only the members of that group, rather than their constituency as a whole."285 These are all consequentialist concerns. Similarly, when Justice O'Connor wrote in Croson that "[c]lassifications based on race carry a danger of stigmatic harm . . [ [and] may in fact promote notions of racial inferiority and lead to a politics of racial hostility," ${ }^{286}$ she described a set of untoward consequences that could flow from a government practice by virtue of an idea, or a set of ideas, that such a practice might communicate. ${ }^{287}$

282 Brown, 347 U.S. at 494 (quoting a separate, unreported finding of a three-judge court sitting in Brown, 98 F. Supp. 797 (D. Kan. I 95 I)).

283 Shaw, 509 U.S. at 647 .

284 Id. at 648.

285 Id. Note that at least some of the ideas that the Shaw Court was concerned with prohibiting the state from communicating are empirically correct: there are in fact significant correlations between race and voting behavior. See sources cited supra note $25 \mathrm{I}$.

286 City of Richmond v. J.A. Croson Co., 488 U.S. 469, 493 (I989) (plurality opinion); see also Shaw, 509 U.S. at 643 (arguing that classifications based solely on race "threaten to ... incite racial hostility" (citing Croson, 488 U.S. at 493; and United Jewish Organizations of Williamsburgh, Inc. v. Carey, 430 U.S. I44, I 73 (1977) (Brennan, J., concurring in part))). Theorists who prefer the revelatory approach to expressive harm deny that discussions like these are about expressive harm at all. See, e.g., Anderson, supra note 40 , at I $232 \&$ n.I46.

287 This consequentialist, message-oriented understanding of expressive harm also appears in Establishment Clause cases. In Lynch v. Donnelly, 465 U.S. 668 (I984), for example, Justice 
On a consequentialist view of expressive harm, disparate impact doctrine would be problematic if the message it sent affected the views, norms, and behavior of people in society in ways that contravene the values of equal protection. Such a message might flow from the doctrine's use of racial categories as units of analysis. Disparate impact cases always group people by race, because the validity of challenged employment practices is measured partly in terms of the resulting allocation of employment opportunities among racial groups. That process might send the disfavored message that government sees people as members of racial groups rather than as individuals. ${ }^{288}$ If the expression of that message affected people's attitudes such that they related to themselves and others as members of racial groups rather than as individuals, disparate impact doctrine might fall afoul of equal protection.

I. Problems with the Consequentialist Approach. - There are, however, at least three kinds of reasons - normative, doctrinal, and practical - why one should hesitate to analyze the constitutionality of disparate impact doctrine - or any doctrine - according to a consequentialist vision of expressive harm. Begin with the normative reason. One of the prime consequences that expressive harm analysis seeks to avoid is racial hostility. Unfortunately, racial hostility routinely flows from major legal changes designed to end discrimination, not just from affirmative action and disparate impact laws. There is no doubt, for example, that Brown caused a great deal of racial hostility, as did the passage of the disparate treatment provisions of Title VII. ${ }^{289}$ It does not necessarily follow that the costs of provoking hostility should get no consideration whatsoever in equal protection law, but it does follow that courts should be circumspect about allowing such hostility to veto government action aimed at improving the position of disadvantaged groups.

A second problem with the consequentialist approach to expressive harm is doctrinal. Under Washington v. Davis, judicially enforced equal protection is supposed to be concerned with motives rather than with effects. ${ }^{290}$ Taking Davis seriously would seem to mean that the effects of a law, including the impact of its perceived social meaning,

O'Connor explained that government endorsement of a religion is invalid because it sends a message to some people that they are insiders and to others that they are outsiders. Id. at 688 (O'Connor, J., concurring).

288 See supra Part III.

289 See Kennedy, supra note 4I, at $1330-3 \mathrm{I}$ (arguing that white resentment has accompanied "every effort to undo racial subordination" and that the "inevitability" of this resistance should make proponents of such reform "wary of allowing fear of white backlash to limit the range of reforms pursued").

290 Washington v. Davis, 426 U.S. $229,238-39$ (1976). 
cannot be a reason why that law violates equal protection. ${ }^{291}$ Consider again the statement in Croson, repeated in Adarand, that express racial classifications carry a danger of stigmatic harm. ${ }^{292}$ Perhaps they do. But under Davis, the fact that such classifications may have a stigmatizing effect cannot be a reason to subject them to strict scrutiny unless they are motivated by the intent to stigmatize. ${ }^{293}$ Davis should therefore have protected racially classificatory affirmative action against being subject to strict scrutiny based on the risks that stigma and racial hostility would result. ${ }^{294}$ It is the case, of course, that Croson and Adarand did give weight to the possible expressive consequences of racial classifications, ${ }^{295}$ such that the present objection to the consequentialist approach has in some sense already been overridden. But the attendant internal contradictions in equal protection doctrine should continue to give us pause.

Finally, and perhaps most importantly, there is a practical problem with the consequentialist approach to expressive harm. As a matter of institutional competence, the consequentialist analysis would be difficult for a court to apply accurately. The effects of any policy are not easy to identify, much less to quantify. ${ }^{296}$ In other areas of equal protection law, judges and commentators alike regard as a given the limited competence of courts to assess the real-world effects of particular policies. ${ }^{297}$ Here, we are dealing with the effects of a message, which would seem to be even more difficult to assess than the effects of a concrete policy. It is most unlikely that courts could measure them.

291 Unless, of course, those effects are treated as evidence of an invalid motive, id. at 242 , but that is not the situation under discussion here. We are concerned, for the moment, with an approach to expressive harm that is interested in consequences. Discussion of what a law's message might reveal about a legislature's motive follows in the next section.

292 See cases cited supra note 279.

293 See Davis, 426 U.S. at 238-39; see also Rubenfeld, supra note 40, at II 74-75. Note that the Court in, for example, Croson or Adarand cannot be interpreted as using those possible consequences as evidence that the classifications were in fact motivated by a desire to stigmatize or to promote notions of racial inferiority. Nobody argues, and probably nobody believes, that the majority-black Richmond city council enacted its affirmative action program for municipal contracting in order to stigmatize African Americans.

294 See Rubenfeld, supra note 40, at I $174-75$.

295 See supra note 279.

296 See, e.g., Regan, supra note I00, at i 890.

297 See, e.g., Pers. Adm'r v. Feeney, 442 U.S. 256, 272 (1979) ("The calculus of effects, the manner in which a particular law reverberates in a society, is a legislative and not a judicial responsibility." (citing Dandridge v. Williams, 397 U.S. 47 I (1970); and San Antonio Independent School District v. Rodriguez, 4 I I U.S. I (I 973))); Brest, supra note I, at 26 (referring to "the judicial unmanageability of a general rule requiring an extraordinary justification for practices that produce racially disproportionate effects"); Fiss, supra note I, at I74-75 (stating that the "[s]ubtle factual inquiries" required of judges under a "group-disadvantaging interpretation" of the Equal Protection Clause "will strain the resources, the imagination and even the patience of the judiciary"). 
The odds against an accurate assessment appear even larger when one recognizes that laws do not send unique and determinate messages. A court evaluating the communicative impact of a law would first have to decide what message that law sent. If a law meant different things to different people - and most social phenomena do then a consequentialist calculus would require the court to identify several different messages and to assess the separate impacts of each individual message. Of those different impacts, some might be socially harmful and therefore qualify as expressive harms on a consequentialist theory, but others might be socially beneficial. Disparate impact law might send the disfavored message that people should be seen as members of racial groups, but it might also send the message that government is serious about ensuring fair employment opportunities for everyone, in spite of structural hierarchies inherited from times of official discrimination. Assessing the overall impact of a law's messages would thus require summing the effects of positive and negative messages. Each step of the analysis would entail a fair bit of empirical guesswork; this guesswork might render a court's conclusion little more than a judicial hunch. ${ }^{298}$

2. Applying the Consequentialist Approach to Title VII. - Despite these problems, however, consequentialist approaches to expressive harm do appear in equal protection cases. As a matter of practice, the opinions in such cases tend to simplify the problems they face by declining to entertain the possibility that state action could have both positive and negative communicative impacts at the same time, such that a reviewing court would have to decide whether the net effects were positive, negative, or neither. Instead, the tendency is to ask only whether there are negative messages and to evaluate state action based on those. ${ }^{299}$ In Shaw, for example, the Court asked whether a district-

$298 C f$. Anderson, supra note 40, at $1237-38$ (arguing that courts may be competent to balance the benefits and harms faced by particular parties but are not competent to analyze costs and benefits to society at large); Christopher L. Eisgruber, Democracy, Majoritarianism, and Racial Equality: A Response to Professor Karlan, 50 VAND. L. REV. 347, 355-56 \& n.28 (1997) (arguing that the most important question in the controversy over majority-minority redistricting - a $l o$ cus classicus of expressive harm theory - is whether the practice would, in the end and on balance, reduce or exacerbate racial tensions, and further arguing that it might do either, and that it is very hard for a court to predict which effect would prevail).

299 Grutter provides the closest thing to an exception when it discusses the problem of social meaning in a world without affirmative action. "In order to cultivate a set of leaders with legitimacy in the eyes of the citizenry," the majority opinion states, "it is necessary that the path to leadership be visibly open to talented and qualified individuals of every race and ethnicity." Grutter v. Bollinger, I 23 S. Ct. 2325, 2341 (2003). In other words, if the "path to leadership" is not perceived to be open to members of certain racial minority groups, the public (or segments of it) will doubt the legitimacy of those who ultimately ascend to leadership positions. The Court is here concerned about appearances: note the language of eyes and visibility. In stating that affirmative action at a key point of entry to public leadership positions is necessary to create appearances that are essential for political legitimacy, the Court is justifying affirmative action in 
ing plan communicated a disfavored idea about the link between race and politics, ${ }^{300}$ not whether any such idea was outweighed by other, salutary ideas that the districting plan might also communicate (for example, that it is important to enable the election of AfricanAmerican representatives in the face of continued racial polarization in the electorate). The same is true in the religious establishment cases: private school vouchers and town square nativity scenes are acceptable not because they send positive messages that outweigh the negative ones but because they simply do not send negative messages. ${ }^{301}$ Thus, the consequentialist inquiry is not an all-things-considered consequentialist inquiry. It simply asks whether a practice communicates ideas with consequences adverse to constitutional values. ${ }^{302}$

Once a court identifies a troublesome message, the amount of expressive harm that such a message causes can be thought of as the product of two factors. The first factor is the degree to which the message is disfavored by the values of equal protection. Of the set of messages that offend equal protection, some are worse than others. ${ }^{303}$ I will call the second factor the "visibility" of the message, by which I mean the degree to which the communicative aspect of the challenged practice actually impresses itself on some large or otherwise significant audience. The consequentialist concern is about damage done by a message a practice sends, and there is no damage if nobody gets the message. ${ }^{304}$

There are many potential audiences, and they can absorb the law's messages in different ways. The general public is one audience, but it

elite law school admissions in part by reference to the expressive benefit that affirmative action in such a context yields. The Court does not here explicitly weigh expressive benefits against expressive harms, but it does so implicitly. As Justice O'Connor, author of the majority opinion in Grutter, previously wrote in Croson, affirmative action programs are subject to strict scrutiny in part because of the expressive harms that such a program entails. See City of Richmond v. J.A. Croson Co., 488 U.S. $469,493(1989)$ (plurality opinion). The affirmative action program in Grutter survived strict scrutiny in part because of its expressive benefits.

300 See Shaw v. Reno, 509 U.S. 630, 647-49 (1993).

301 See Zelman v. Simmons-Harris, 536 U.S. 639, 654-55 (2002) (vouchers); Lynch v. Donnelly, 465 U.S. $668,683-86$ ( 1984 ) (nativity scene).

302 This pattern may reflect the pull of the other, revelatory approach to expressive harms. On the revelatory theory, a reviewing court does not balance impermissible valuations against permissible ones. Instead, it asks whether impermissible valuations are present, and if so, it invalidates the legislation, just as it would if it concluded that the motive for a law were impermissible. See infra section IV.B. As there is no developed doctrine of expressive harm overall, reviewing courts may (more or less unthinkingly) find themselves approaching problems of law's social meaning from a variety of different perspectives. In this case, that might mean borrowing a concern with effects from the consequentialist model and a focus only on impermissible valuations from the revelatory one.

303 Cf. supra note 280 (discussing different forms of the idea that people are importantly constituted by race).

304 This orientation explains the Shaw Court's statement that appearances can matter. 509 U.S. at 647 . 
is also composed of many sub-audiences. In addition, the government agents who carry out state action are an audience for that action, aware of and perhaps affected by the implicit messages of that action even if few others are aware of it. ${ }^{305}$

For each audience, the message a state action imparts can become visible in more than one way. Sometimes, as with expressive harms caused by express classifications, a disfavored message is sent through the wording of a statute. ${ }^{306}$ But the language of Title VII does not present such a clear case. As discussed in Part I, Title VII articulates its concern with racial allocation in a more convoluted way. Whatever damage flows from the words that are held to create Title VII's disparate impact doctrine should therefore be less than that expected in cases such as Adarand.

It cannot be sound, however, to give too much attention to forms of words in statutes or regulations when inquiring about the possibility of consequentialist expressive harms. Legal language is visible, but very few people read statutes and regulations, and those who do generally have other levels of awareness about how government actually carries out its policies. Nor would it make sense to confine a doctrine concerned with the damage caused by messages to the messages sent by overt language. Unless the doctrine of expressive harm is woodenly concerned with magic phrases, assessing the danger that disfavored messages pose to the advancement of equal protection values requires us to look beyond the statutory language and see what message is sent by the operation of a given practice.

The government actions at issue in Adarand and Shaw provide some guidance for figuring out whether disparate impact doctrine would be held to cause expressive harm in its operation. ${ }^{307}$ The affirmative action program challenged in Adarand sent visible disfavored messages each time a minority-owned contractor was awarded a contract even though a white contractor had tendered a lower bid, provided the information about each bid was public. The immediate audience for this message might be relatively small, consisting only of the people aware of the contract award. But to that small audience one must add the larger audience that was made aware of such affirmative action programs through the media or other forms of com-

$305 C f$. id. at $648-49$ (noting the message that districting sends to elected representatives). I thank Don Herzog for reminding me of the importance of this point.

306 Croson's preoccupation with the danger of stigmatic harm arising from an express racial classification in a statute or ordinance is an example. See City of Richmond v. J.A. Croson Co., 488 U.S. 469, 493-94 (1989) (plurality opinion).

307 Grutter and Gratz do not engage in overt discussion of expressive harms, though there is an implicit hint about the function of expressive benefits in Grutier's concern with cultivating political legitimacy. See supra note 299. 
munication. Racially classificatory affirmative action is a well-known phenomenon to the American public, visible even to those who do not experience it directly.

Shaw illustrates the importance of mediated explanation. Someone confronting North Carolina's districting plan without the benefit of such explanation would be unlikely to receive a disfavored message about politics and race, because getting that message requires a fair amount of specialized knowledge. Despite the Court's suggestion that the "bizarre shape" 308 of the challenged congressional district spoke for itself, clearly communicating its origin in racially allocative politics, ${ }^{309}$ a shape on a map cannot send that message to a recipient who does not already know a good deal about the surrounding circumstances. For reasons including topography and partisan gerrymandering, many congressional districts have shapes no less bizarre than districts drawn to be majority-black. ${ }^{310}$ The message that North Carolina's District I 2 was shaped largely by racial considerations was communicated only when the geography of the district was interpreted in light of background understandings that some informed people had about the politics and demography of North Carolina. ${ }^{311}$ Those understandings became widely available when the plan was challenged, because the public litigation made the racial aspect generally visible. ${ }^{312}$

At present, disparate impact liability is not as well-known a phenomenon as racial gerrymanders or classificatory affirmative action. I suggest that a great many people are unaware that it exists at all..$^{313}$ As long as that circumstance continues, disparate impact doctrine can avoid being much of an expressive harms problem, at least in the consequentialist sense. Indeed, it is hard to know whether society's greater tolerance for disparate impact doctrine than for affirmative action and race-conscious districting stems from disparate impact doc-

308 Shaw, 509 U.S. at $655-56$.

309 See id. (holding that appellants stated a valid claim by alleging that the districting plan, "though race neutral on its face, rationally cannot be understood as anything other than an effort to separate voters into different districts on the basis of race").

310 See, e.g., Richard H. Pildes, Principled Limitations on Racial and Partisan Redistricting, I06 YALE L.J. 2505, 25 I5 \& n.36, 2550 (1997).

311 Given the extreme rarity with which majority-white congressional districts elect black representatives, see Pildes, supra note $25 \mathrm{I}$, at $\mathrm{I} 368$, one might speculate that the election of a black representative is another way in which the drawing of a congressional district sends a visible message that it was drawn with the race of voters in mind. But the Court is estopped from considering this as a factor by its ideological rejection of the proposition that only black voters can be presumed to be supporters of black candidates. See id. at 1365-66.

312 The New York Times ran a map and commentary on the front page. See Linda Greenhouse, Court Questions Districts Drawn To Aid Minorities, N.Y. TIMES, June 29, I993, at Ar.

313 This is not because the statutory language is unclear - I suspect that people who read the statute also know how it has been interpreted. I think it more likely to be because of a generally low level of awareness outside the world of legal professionals, large employers, and union officials that section $703(a)(2)$ of Title VII exists at all. 
trine's greater compatibility with popular conceptions of individualist equality or simply from its lower profile. It is at least plausible that if more attention were paid to the dynamics of disparate impact liability, disparate impact law might become the source of disfavored messages about the importance of allocating jobs among social groups. ${ }^{314}$ There is, to be sure, something curious about a constitutional doctrine that would permit a relatively unknown government practice but find the same practice invalid if it became publicized. But that is the nature of a doctrine that is concerned with the consequences of the messages a given practice sends.

If disparate impact doctrine were to become more visible, which would likely happen if serious efforts were made to challenge its constitutionality, many people would understand the doctrine as evincing some kind of government concern with the allocation of employment among racial groups. Close knowledge of the doctrine would reveal that Title VII does not demand racially proportional employment and permits disparate impact on a sufficient showing of business necessity, but a rough understanding would include, correctly, the recognition that classifying people into racial groups and asking whether each group has a fair share of employment positions is a central element of the doctrine.

We now confront a subtle difference between the analysis of motive and the consequentialist approach to expressive harm. When a court constructs the motive behind a law, it can draw upon all of its specialized knowledge of that law, including all the details of its passage and operation. If closely reasoned arguments of the kind adduced in Part II can support the conclusion that Title VII's disparate impact law does not necessarily (or exclusively, or predominantly) aim at racial allocation, ${ }^{315}$ the court is free to adopt that conclusion. But on the consequentialist model of expressive harm, a court does not ask what an expertly informed investigator might understand about the statute; nor is the question what a hypothetical reasonable observer would understand. Instead, the relevant question is what the public is likely to understand in fact.

The more complex a law, the less likely that a large lay audience will appreciate its subtleties and qualifications. It is for that reason that the consequentialist approach to expressive harms must hold, with

314 President George H.W. Bush opposed the extension of Title VII disparate impact liability in precisely this way, characterizing the Civil Rights Act of I990 as a "quota bill." See Ayres \& Siegelman, supra note $26 \mathrm{I}$, at 1489 . In so doing, he attempted to raise the profile of Title VII's disparate impact doctrine and to highlight (and overstate) its tensions with individualist equal protection values.

315 See supra section II.C. 
the Shaw Court, that "appearances do matter."316 If disparate impact doctrine appears group-oriented, then the consequentialist approach to expressive harms would likely argue for the law's invalidity. There is little doubt that the opponents of disparate impact liability would portray it in starkly group-oriented terms, ${ }^{317}$ and preventing that portrayal from taking hold as a popular conception might require a more subtle argument than usually succeeds in mass politics. For all these reasons, it is foreseeable that Title VII's disparate impact doctrine could eventually be held to cause expressive harms.

\section{B. The Revelatory Approach: Evincing Government Attitudes}

Consequences do not provide the only reason for concluding that a law's expressive harms render it invalid as a matter of equal protection. On another understanding, expressive harms analysis is concerned with what a legislature reveals about its own attitudes when it makes a particular law. Elizabeth Anderson and Richard Pildes are leading proponents of this perspective. On their view, the rubric of expressive harm should not focus on the material consequences that flow from state communications. ${ }^{318}$ Rather, the concern with expressive harm seeks to regulate the reasons for action..$^{319}$ If the state acts in a way that expresses - in the sense of "reveals" - an inappropriate normative attitude, then the action is invalid. ${ }^{320}$

This understanding of expressive harm looks at a legislature's collective state of mind ${ }^{321}$ rather than the product of its actions. It is in this way more similar to the analysis of legislative motive than to the analysis of a law's communicative effects. ${ }^{322}$ It would be a mistake, however, to conflate the revelatory approach with traditional motive analysis. An actor's motive for doing something is not the same as the set of attitudes that the actor reveals by doing that thing. The male

316 Shaw v. Reno, 509 U.S. 630, 647 (1993). Notice how the revelatory approach differs from the consequentialist approach in its treatment of appearances. In a consequentialist analysis, appearances matter even if they do not accurately reflect either the motivations or the values behind a law - and even if they are misleading. The revelatory approach, however, works through the reasonable observer, and the reasonable observer would not be fooled by misleading appearances any more than a court believes that it would be fooled itself.

317 See Ayres \& Siegelman, supra note 26r, at I489-90 (describing how opposition to the codification of disparate impact doctrine in the late 1980 and the early I 990 s was framed as opposition to quotas).

318 Anderson \& Pildes, supra note 274 , at 1531.

319 Id. at $15 \mathrm{I} \mathrm{I}$.

320 Id. at $153 \mathrm{I}$.

321 Anderson and Pildes accordingly confront the familiar questions about whether and how it can make sense to attribute a state of mind to a collective body like a legislature. See id. at I5 I427.

322 See id. at 1542 (distinguishing "harms inherent in the principle on which the laws are enacted" from consequential harms). 
boss who propositions his female subordinate may be motivated by lust, but he may also reveal an attitude about class or social status by trying to exercise a privilege of his position; ${ }^{323}$ we often reveal our contempt for other people by casual and unpremeditated actions rather than by design. ${ }^{324}$ The theory of subconscious discrimination is in part a theory about attitudes that shape behavior even though the actor does not understand himself to be motivated by those attitudes, or even to hold them. ${ }^{325}$ Similarly, revelatory expression includes both the things that a speaker or state actor wants to say about itself and the things that it unwittingly betrays about itself through its actions. ${ }^{326}$

According to Anderson and Pildes, the meaning of a law that the doctrine of expressive harm evaluates is not necessarily the meaning that a legislature intends to express, nor is it necessarily what the general public actually understands that law's meaning to be. ${ }^{327}$ Instead, it is the law's contextually objective "public meaning." 328 This view that the relevant meanings are independent of the subjective understandings of both speaker and audience - can draw support from existing case law. Consider, for example, the "reasonable observer" test in Establishment Clause cases, which asks whether state action would carry the meaning of religious endorsement to a hypothetical person who was reasonable and appropriately well informed about the content, history, and context of the practice at issue. ${ }^{329}$ The Court has not

$323 C f$. DON HERzog, POISONING THE Minds OF THE LOWER ORders 2 I 6-i 7 (I 998 ).

324 See William IAN Miller, The ANATOMY OF DisguST 208 (I997).

325 See supra pp. 532-33; see also IAN AYres, Pervasive PrejUdice? UnConvenTICNAL EVIDENCE OF RACE AND GENDER DISCRIMINATION 418-25 (2001) (discussing ways to test for unconscious disparate treatment).

326 In this way, my distinction between consequentialist and revelatory approaches to legal expression differs from Sunstein's division of legal expression into (I) expression aimed at changing norms or producing consequences and (2) expression with which the speaker aims to say something about who he is, regardless of consequences. See Sunstein, supra note 273, at 820-23; Sunstein, supra note 274 , at $2025-28$. Like my distinction, Sunstein's differentiates a consequentialist approach from a nonconsequentialist one. Unlike mine, however, Sunstein's nonconsequentialist category is limited to things the speaker intends to say.

327 See Anderson \& Pildes, supra note 274, at $1523^{-25}$.

328 Id.

329 See Zelman v. Simmons-Harris, 536 U.S. 639, 654-55 (2002); Good News Club v. Milford Cent. Sch., 533 U.S. 98, I 9 (200I); Mitchell v. Helms, 530 U.S. 793, 843 (2000) (O'Connor, J., concurring in the judgment) (arguing that government funds flowing to private religious schools via independent decisions of private individuals do not constitute a prohibited religious establishment under circumstances where "[n]o reasonable observer is likely to draw from the facts ... an inference that the State itself is endorsing a religious practice or belief" (alteration and omission in original) (quoting Witters $v$. Washington Department of Services for the Blind, 474 U.S. $48 \mathrm{I}, 493$ ( $\mathrm{I} 986$ ) (O'Connor, J., concurring in part and concurring in the judgment)) (internal quotation marks omitted)); Capitol Square Review \& Advisory Bd. v. Pinette, 5 I5 U.S. 753, 77980 (1995) (O'Connor, J., concurring in part and concurring in the judgment); Lynch v. Donnelly, 465 U.S. 668, 690 ( 1984 ) (O'Connor, J., concurring) (arguing that the constitutionally relevant meaning of a government action challenged under the Establishment Clause is partially depend- 
explicitly extended the reasonable observer model to equal protection cases, but Anderson and Pildes argue that a similar test should apply there as well. ${ }^{330}$ What matters on this view is not what the legislature intends to express but what the legislature's actions would reveal to a reasonable or objective audience. ${ }^{331}$

Unfortunately, courts might not be very good at deciding what valuations a law expresses. The difficulty goes beyond that of attributing a worldview to a collective actor like a legislature. There is also the problem of having to construct a reasonable observer whose perspective will establish what the legislature reveals through its actions. It is a tenet of the revelatory approach to expressive harm that such a perspective can be constructed and that it is possible from that perspective to identify contextually objective meanings of state actions. ${ }^{332}$ Indeed, this must be possible despite the fact that different people in society perceive social meanings differently.

Sophisticated adherents to the revelatory view, like Anderson and Pildes, acknowledge that people from different demographic groups say, blacks and whites, or men and women - will often see different meanings in the same actions, including or perhaps especially when the actions concern the relationships among those demographic groups. ${ }^{333}$ Nonetheless, Anderson and Pildes maintain that reasonable or objective public meanings exist and that constitutional doctrine can function based on the identification of such meanings by courts. ${ }^{334}$ I am less certain.

ent on its "'objective' meaning . . . in the community," rather than wholly a function of either the legislature's intended meaning or the meaning understood by the actual public). This is an objective test in the same sense that the reasonable person standard in tort is objective. See Capitol Square, 5 I5 U.S. at $779-80$ (O'Connor, J., concurring).

330 See Anderson \& Pildes, supra note 274 , at I539 (arguing that "[e]ven if no one accepted ... [a negative] racial message [conveyed by racial redistricting], the Court would probably reach the same constitutional result" of striking down the redistricting scheme).

331 The revelatory approach to expressive harm, like the consequentialist approach, is in tension with the doctrinal rule that equal protection analysis is not concerned with the unintended or non-motivating consequences of a law. Consider that a legislature that values the welfare of blacks less than the welfare of whites will have an easier time enacting laws with disparate impact on blacks, even if it is not motivated by a desire to discriminate against blacks. The enactment of those laws may reveal the legislature's impermissible valuation in the same way that the subconscious prejudices of the subconscious discriminator are revealed through his greater tolerance for arrangements in which people of particular groups fare badly. See supra p. 534. But under Davis and Feeney, such laws are not equal protection problems, just as the subconscious discriminator does not violate equal protection. See generally Krieger, supra note I60; Lawrence, supra note 18 . That is a problematic conclusion for the revelatory view of expressive harm: the proposition that the legislature may not act in ways that reveal impermissible valuations is at odds with basic equal protection doctrine over the status of laws conditioned, but not motivated, by impermissible valuations.

332 See Anderson \& Pildes, supra note 274 , at $1524-25$.

333 Id

334 Id. at $1525-26$. 
Many or most reasonable African Americans may see social meanings about inequality in laws that do not carry such meanings for many or most reasonable whites. ${ }^{335}$ Conversely, and crucially for evaluations of disparate impact laws, many reasonable whites may see race-conscious laws designed to remedy the continuing effects of historical discrimination as carrying meanings other than those that many reasonable nonwhites might see. The necessity of evaluating a law from the viewpoint of the reasonable observer requires a court to choose one perspective as reasonable. In principle, that perspective need not be the actual perspective of any particular person. It could instead be a construct that takes into account what is seen from different perspectives. When a jury is asked to apply a reasonableness standard, the need to secure the assent of twelve different people helps prevent "reasonableness" from being the projection of any one person's perspective. The broader the perspectives of the jurors, the more the inquiry into reasonableness will, if it works properly, force people to consider perspectives other than their own. But when a judge (or a small number of judges with similar perspectives) asks what a reasonable observer would perceive, he or she must make a greater effort to discipline the inquiry and to prevent his or her own subjective perspective from pronouncing itself reasonable. Unlike a juror, a judge is not required to reach agreement with anyone else, even if he or she sits on a multimember court. ${ }^{336}$ Accordingly, there is a danger that the reasonable observer's perspective will in practice be the perspective of empowered insiders, and the perspective of disempowered outsiders will be deemed subjective and particular only. ${ }^{337}$

I suspect that this danger accurately describes how the reasonable observer standard is applied in constitutional cases. Nothing in the case law disciplines the inquiry into the reasonable observer's perspective, and the Court is left to consult its own intuitions about reasonableness. As a result, the valuations that a legislature is deemed to ex-

335 See generally DONALD R. Kinder \& LYNN M. SANDERS, Divided By COLOR: RACIAL POLITICS AND DEMOCRATIC IDEALS (I 996 ) (using public opinion data to demonstrate the deep divide between whites and blacks over racial policy). A parallel phenomenon is visible in cases in which the trappings of Christian holidays, such as Christmas trees, are not regarded as endorsing or promoting any particular religion. See, e.g., Lynch v. Donnelly, 465 U.S. 668, 69 I (1984) ( $\mathrm{O}^{\prime}$ Connor, J., concurring).

336 However, for a discussion of the ways in which the presence of judges with differing viewpoints does affect the reasoning of multimember panel courts, see Richard L. Revesz, Congressional Influence on Judicial Behavior? An Empirical Examination of Challenges to Agency Action in the D.C. Circuit, 76 N.Y.U. L. REV. I Ioo, I IO7, I I IO-I 2 (200I), and sources cited therein.

337 It should also be remembered that the diversity of views about the meaning of a law is not just a matter of people of different races holding different views. Within each group, there is also a diversity of viewpoints. On the different ways in which black Americans perceive the subject matter of cases like Shaw, see Katherine Tate, Black Opinion on the Legitimacy of Racial Redistricting and Minority-Majority Districts, 97 AM. POL. SCI. REv. 45, 45-46 (2003). 
press will largely turn out to be the valuations as seen by mainstream whites, ${ }^{338}$ and laws touching on issues of racial equality will stand or fall based on how they appear from that perspective. ${ }^{339}$

A bitter corollary is that African-American perspectives on laws touching issues of race will appear "reasonable" only to the extent that they can be made persuasive to a large number of whites. Otherwise, if blacks see state action as evincing different legislative values than whites - for example, if blacks see a legislature's tendency to enact statutes with disparate impacts as evincing a background belief that the welfare of blacks matters less than the welfare of whites - it is "because the colored race chooses to put that construction upon it." 340 Equal protection need not take notice.

Despite these weaknesses in the revelatory approach, the Court does apply something like it, at least some of the time. Indeed, the Court often seems quite comfortable pronouncing the social meaning of state action. ${ }^{341}$ It is therefore necessary to ask how Title VII's disparate impact doctrine would fare under that approach. What is the "public meaning" of disparate impact doctrine? What would the Court's well-informed reasonable observer conclude about the worldview of Congress based on the existence of the doctrine?

There is a range of possible answers. Disparate impact law might indicate that the legislature seeks fair employment opportunities for people of all races, considered in light of pervasively unequal conditions inherited from an era of state-sanctioned discrimination. Alternatively, it might show that the legislature thinks of individuals as importantly constituted by membership in racial groups. ${ }^{342}$ Another possibility is that the legislature believes that people of certain racial groups cannot succeed in workplace competition with whites unless

338 In religious establishment cases, the same is true but with "Christians" or "Protestants" inserted for "whites."

339 To be sure, one might extend this point to argue that because median judges tend to be mainstream whites, all judicial decisionmaking, and not merely that officially based on reasonable observers, must be consistent with what the perspective of those mainstream whites will bear. The point is fair, and the countervailing hope is that public decisionmakers will learn to think from perspectives other than their own. In the context of expressive harm analysis, however, that hope is in tension with a doctrine that explicitly calls upon a court to imagine one perspective as reasonable, rather than encouraging judges to confront the multiplicity of reasonable views that are likely to exist on a given subject.

340 Plessy v. Ferguson, I63 U.S. 537, 55 I (1896).

341 See, e.g., cases cited supra note 329; Shaw v. Reno, 509 U.S. 630, 647 (I993) (arguing that a race-based reapportionment plan reinforces the perception that racial groups think alike); City of Richmond v. J.A. Croson Co., 488 U.S. 469, 493 (1989) (plurality opinion) (arguing that racial classifications may promote notions of racial inferiority and lead to a politics of racial hostility).

342 Again, this could mean either that people's life chances are partly determined by racial circumstances or that race should be an important part of how people should subjectively think of themselves and others. See supra note 280 . 
the rules are altered to make success possible. ${ }^{343}$ These are not the only possibilities, nor need any of these options exclude the others. In principle, a reasonable observer might infer any combination of these and other attitudes from the prohibition on disparate impact.

Identifying the relevant public meaning of disparate impact law requires one to try to think from the perspective of the Court's reasonable observer, and the best way to begin that exercise is to note what the Court's reasonable observer has made of other kinds of raceconscious state action. Consider Shaw, a core case for the theory of expressive harm ${ }^{344}$ and one in which the subject matter is similar to disparate impact law in several ways already explored. ${ }^{345}$ The Shaw Court believed that North Carolina's drawing of majority-black congressional districts revealed inappropriate attitudes about the relationship between race and political identity. According to the Court, these attitudes reflected an expectation that people vote based on their race and that representatives from majority-black districts are chiefly responsible for representing a subset of their constituents - the black ones - rather than all of them. ${ }^{346}$

These were not the only attitudes that might have been taken to be the public meaning of the contested districting plan. Maybe a reasonable observer examining that plan in light of history and context would understand the legislature to have expressed the view that it is important, in a state that had elected no African Americans to Congress in more than a hundred years, ${ }^{347}$ to have a voting system that enables the election of a few black representatives in spite of continuing racial prejudice among white voters. That attitude seems consistent with the values of equal protection. But that was not the meaning that the Shaw Court recognized. This choice should not be surprising, because the Court's preferred perspective on equal protection tends to obscure the role of history and to promote values of presentist individualism. Rather than seeing a group-oriented practice as

343 This is the meaning that Justice Thomas sees in the use of race-based affirmative action. See Grutter v. Bollinger, I 23 S. Ct. 2325, 2350 (2003) (Thomas, J., concurring in part and dissenting in part).

344 See, e.g., Pildes \& Niemi, supra note 274 , at 506-10.

345 Both involve a complex mix of individual and group treatment, both are arguably motivated by a cluster of factors among which racial allocation is one, and the constitutionality of each may turn on the degree to which that factor predominates. See supra Parts II \& III.

346 See Shaw, 509 U.S. at 647-48.

347 See Lublin \& Voss, supra note 217 , at 768 (noting that in 1992 five Southern states that had elected no black representatives to Congress at any previous time in the twentieth century elected black representatives in that year from majority-black districts); Pildes \& Niemi, supra note 274 , at 49I (noting that the two African Americans elected from majority-black districts in North Carolina in 1992, under the plan at issue in Shaw, were the first blacks elected to Congress from North Carolina since Reconstruction). 
redressing historical discrimination, the Court is inclined to see it as revealing a disfavored attitude about race or racial minorities today. ${ }^{348}$

If it followed that the reasonable observer would see any grouporiented, race-conscious state action as revealing impermissible attitudes, then disparate impact law would be doomed. But that conclusion does not follow. Race-conscious districting has been upheld where race played a slightly less prominent role in districting decisions than it did in Shaw, ${ }^{349}$ and even facially classificatory affirmative action has been upheld where the racial consideration was only one nonpredominant factor among several. ${ }^{350}$ As was true of motive analysis, it must therefore be the case that expressive harm analysis can tolerate race-conscious state action if the degree to which the state action reveals troublesome attitudes about race does not exceed a certain level. Disparate impact doctrine might therefore avoid the expressive harm problem if its racially allocative aspect does not overwhelm other elements of the doctrine, such as the respect for business rationality embodied in the business necessity defense.

Ultimately, however, it is extremely difficult to determine what the balance of attitudes revealed by disparate impact law would be in the mind of the reasonable observer. Neither the Court nor the academic defenders of this approach to expressive harm have offered criteria that could meaningfully discipline a judicial inquiry into the mind of the reasonable observer, with the result that the construction of that perspective will draw heavily on the reviewing court's own intuitions. Without such disciplining criteria, a court's assessment of the permissibility of the background valuations expressed by a given government practice is likely to be shaped by the court's level of normative comfort with the practice itself. Just as the question whether disparate impact doctrine uses express classifications cannot be easily separated from the underlying question whether disparate impact doctrine comports with equal protection, neither can the question whether disparate impact law reveals impermissible attitudes held by the legislature be separated from that underlying question.

This is not to say that the relative subtlety of the racial group treatment in disparate impact cases is not a factor making it more likely that disparate impact doctrine will survive constitutional scrutiny. It very well may be. If that subtlety helps prevent the Court from finding disparate impact doctrine offensive to equal protection

\footnotetext{
348 See supra Part III.

349 See Easley v. Cromartie, 532 U.S. 234, 237 (2001); see also Bush v. Vera, 517 U.S. 952, 99394 ( 1996 ) (O'Connor, J., concurring) (stating that a race-conscious districting plan may be upheld if the legislative attitude it reveals is not racial allocation for its own sake but rather the need to comply with the Voting Rights Act).

350 See Grutter v. Bollinger, 123 S. Ct. 2325, 2331-32, 2347 (2003).
} 
values in overt and visible ways, the doctrine stands a better chance of being tolerated despite its trafficking in racial groupings. The point is merely that a court more sympathetic to the policy of disparate impact liability is more likely to see no problematic attitude expressed by the operation of that doctrine, and a court more skeptical of any policy that allocates employment opportunities to racial groups is more likely to conclude that Title VII's imposition of disparate impact liability expresses an impermissible view. After all, the reasonable observer's perspective is likely, in practice, to be coextensive with a court's own.

\section{Expressive Harm: Conclusion}

The expressive harm doctrine is not terribly well-disciplined. The cases wobble between a paradigm concerned with impact and consequence and a different paradigm that is concerned with what laws reveal about a legislature's background worldview, and sometimes they mix and match rather than abide fully by the rules of either one. Each paradigm has serious internal weaknesses. The use of an impact test may exceed courts' institutional capacities and may also conflict with a basic general rule of equal protection analysis enunciated in Davis; the revelatory model relies on a reasonable observer perspective that might be particularly ill-advised when the phenomena observed are those that define insider and outsider groups. This is especially so because the doctrine's lack of analytic discipline makes it likely that a court will adopt its own perspective as that of the reasonable observer.

Whether disparate impact doctrine is invalid for reasons of expressive harm would then depend in large part on the same underlying issue that the question whether disparate impact doctrine uses express racial classifications depends on: whether the underlying practice is one that the Court, on other grounds, sees as consistent with a general sense of equal protection. On the consequentialist theory, there remains another important unknown, which is how the public would understand the idea of disparate impact law if a serious challenge to the doctrine made it more highly visible. On that question, one can only speculate. But even if disparate impact doctrine were judged through the consequentialist lens, one might well wonder whether a reviewing court would transcend its own understandings or whether it would allow its normative dispositions to color its prediction of the damage that an offending idea would do.

It would be a mistake to conclude from all this uncertainty that the category of expressive harm has little to do with whether disparate impact law would ultimately be adjudged unconstitutional. Expressive harm analysis is largely about a reviewing court taking stock of its own understanding of the social meaning of a law, and the validity of disparate impact doctrine depends very heavily on exactly that judgment. Accordingly, the trouble is not that expressive harm analysis is 
beside the point. It is that the inquiry, which may well drive the conclusions on issues of group treatment, motive, and express classification, is subject to so little discipline.

\section{CONCLUSION}

Ever since Washington $v$. Davis, courts and lawyers have assumed that liability for disparate impact is consistent with equal protection but lies beyond what judicially enforced equal protection requires. The known issues have been whether the Davis holding is correct and, given that Davis is the law, whether disparate impact statutes are valid enforcement legislation under Section 5 of the Fourteenth Amendment. But equal protection is not static. The rise of individualist and colorblind values in the generation since Davis now makes it necessary to consider a third issue: the affirmative tension between equal protection and disparate impact statutes. This Article has identified and exfoliated that third issue.

The very radicalism of holding disparate impact doctrine unconstitutional as a matter of equal protection suggests that only a very uncompromising court would issue such a decision. In the wake of Grutter v. Bollinger ${ }^{351}$ and Nevada Department of Human Resources $v$. Hibbs, ${ }^{352}$ the present Supreme Court does not seem like that court. But in addition to signaling a limit to the Court's insistence on colorblind individualism, Grutter may open a space in which the conceptual tensions between disparate impact doctrine and modern equal protection can be recognized without implying the unconstitutionality of the statutory doctrine. Grutter invites the broadening of the category of government action subject to strict scrutiny. Now that it is credible to say that strict scrutiny is not always fatal in fact, it may no longer be necessary to pretend that state action raises no equal protection problems in order to preserve its validity. One could imagine, for example, that the judges who decided Brown $v$. City of Oneonta ${ }^{353}$ would be more willing to say that racial descriptions of criminal suspects are "racial classifications" if the resulting strict scrutiny could be survived. ${ }^{354}$ Indeed, applying strict scrutiny in such cases and sustaining the state action in the end would have the advantage of acknowledging that such cases present a conflict between competing values rather than pretending that they do not. The same is true for disparate impact law. A statutory regime that directs government officials (overtly) and private employers (tacitly) to monitor the racial composition of

\footnotetext{
351123 S. Ct. $2325(2003)$.

352123 S. Ct. 1972 (2003).

35322 I F.3d 329 (2d Cir. 2000).

354 See supra pp. 5 I I-I3.
} 
workforces, and that is in some way concerned with the allocation of employment opportunities among racial groups, does raise equal protection issues on the currently prevailing understanding of equal protection. Even on that mostly individualist version of equal protection, disparate impact law is likely to survive. But that survival might now come within the framework of strict scrutiny, after an acknowledgment of the conflict and a weighing of the competing values.

It is too soon to know whether there really is a new strict scrutiny. Grutter could turn out to be an anomaly rather than a new departure. And if it does turn out that strict scrutiny is now something that can frequently be survived, there is very little way of knowing in advance how the new strict scrutiny might function. It seems unlikely that disparate impact doctrine could survive the old strict scrutiny, if that scrutiny were applied on the terms articulated in equal protection cases prior to Grutter. ${ }^{355}$ Nor does it seem reasonable to expect that disparate impact liability could be defended as serving the compelling interests described in Grutter, because those interests are described as unique to the setting of the university and perhaps even more narrowly to a small set of elite law schools. ${ }^{356}$ But if there is now a new kind of strict scrutiny, then its contours are radically indeterminate, perhaps more so even than the motives behind disparate impact law or the animating values of equal protection itself. Hibbs and Grutter hint that disparate impact law could survive strict scrutiny, if such scrutiny were to be applied, but nothing yet supplies tools for understanding the internal workings of such an analysis.

The aim of this Article has been to analyze the conceptual commitments of equal protection and disparate impact law, not to predict the course of future judicial decisions. Moreover, the analysis has not been conducted only from my own preferred normative perspective. After all, the existing bodies of law have not been constructed from my own perspective: there is much in them with which I disagree. In trying to make sense of the commitments of the law, it would not be suf-

355 Even the aggressive conception of disparate impact doctrine as a means of redressing racial hierarchies could probably pass the first part of the official test for surviving strict scrutiny, which is to say that it can be described as serving a compelling government interest. See, e.g., Shaw v. Hunt, 5 I 7 U.S. 899, 909 ( 1996 ) (stating that the interest in redressing the continuing effects of past discrimination may be considered compelling). The narrow tailoring prong, however, presents greater difficulties. Prior cases have held that government action aimed at redressing the effects of past discrimination cannot rest on the general societal fact of historical discrimination. Instead, there must be some reason to believe that the specific workplace or industry that is the subject of the remedial measure was the site of past discrimination that caused the present imbalance. See, e.g., City of Richmond v. J.A. Croson, 488 U.S. 469, 498-99 (I 989) (plurality opinion); Wygant v. Jackson Bd. of Educ., 476 U.S. 267, 276 (I986) (plurality opinion). Under this analysis, Title VII's disparate impact doctrine would not be narrowly tailored, because it covers every industry in every location in America.

356 See Grutter, I23 S. Ct. at 2341. 
ficient or even sound to discount those elements that I disfavor and to accentuate the ones that I prefer. Instead, the analytic project requires the legal interpreter to think from perspectives other than his own.

But having canvassed the commitments of antidiscrimination law as they appear from several perspectives, the legal actor must once again think from his own perspective when choosing which interpretation to adopt. The issue posed when equal protection collides with liability for disparate impact is sufficiently complex, and the question sufficiently close, that any proposed resolution will have weaknesses. The choice among possible resolutions is therefore largely a choice about what weaknesses a given interpreter is prepared to tolerate. It therefore rests on normative concerns.

An interpreter concerned solely with making the body of law cohere might be led to characterize disparate impact doctrine as solely an evidentiary dragnet for hidden deliberate discrimination or present subconscious discrimination. On that understanding, the doctrine is easily compatible with the demands of modern equal protection. But mediating the tension between equal protection and disparate impact in this way would empty disparate impact doctrine of much of the content that makes it valuable. Given the small volume of successful disparate impact litigation in recent years, the continuing value of the disparate impact doctrine is at least as much heuristic and symbolic as it is practical. It no longer reallocates large numbers of jobs, but it does preserve some awareness that existing racial hierarchies are products of past discrimination and that a level-playing-field approach today could help those hierarchies perpetuate themselves indefinitely. If disparate impact law is limited to issues of present states of mind, that structural and historical orientation will be lost. Rather than offering a counterpoint to the presentist, individualist cast of modern equal protection, disparate impact doctrine would then simply be aligned with it. That would not be a good development. After all, antidiscrimination law should not cohere only with itself. It should also fit the social problems that it is aimed to cure. As long as those problems are still in large part about self-perpetuating hierarchies, it would be a mistake to purge concern with hierarchy from the law of discrimination. 